Universidade de São Paulo

Faculdade de Filosofia, Letras e Ciências Humanas

Departamento de Letras Clássicas e Vernáculas

Programa de Pós-Graduação em

Estudos Comparados de Literaturas de Língua Portuguesa

Renata Paltrinieri Hograefe

Capitães da Areia, um estudo comparado entre os Amados - literatura e cinema em diálogo

(Versão Corrigida)

São Paulo

2015 


\section{Capitães da Areia, um estudo comparado entre os Amados - literatura e cinema em diálogo (Versão Corrigida)}

Mestranda: Renata Paltrinieri Hograefe N.USP 3708018

Dissertação apresentada ao Programa de PósGraduação em Estudos Comparados de Literaturas de Língua Portuguesa da Faculdade de Filosofia, Letras e Ciências Humanas da Universidade de São Paulo como pré-requisito para obtenção do título de mestre em Letras.

Orientadora: Professora Doutora Maria Zilda da Cunha

São Paulo 


\section{Capitães da Areia, um estudo comparado entre os Amados - literatura e cinema em diálogo.}

Dissertação apresentada ao Programa de PósGraduação em Estudos Comparados de Literaturas de Língua Portuguesa da Faculdade de Filosofia, Letras e Ciências Humanas da Universidade de São Paulo como pré-requisito para obtenção do título de mestre em Letras.

Orientadora: Professora Doutora Maria Zilda da Cunha.

Aprovado em

$1^{\circ}$. Examinador

Instituição Assinatura

$2^{\circ}$. Examinador

Instituição Assinatura

$3^{\circ}$. Examinador Instituição Assinatura 
A vó Angelina (in memoriam), a minha mãe Deise e a meu filho Henrique, por serem as pilastras que não me deixam cair. 


\section{AGRADECIMENTOS}

A minha avó Angelina, in memoriam, pelos sábios e singelos ensinamentos, pelo riso fácil e pelo colo sempre disponível.

A meu avô Vergílio, in memoriam, por ter transformado minha infância em um momento inesquecível e belo.

A minha mãe Deise que, em muitos momentos, renunciou de sua vida para que eu pudesse prosseguir, ensinando-me o significado de amor materno.

Ao meu eterno amor, Henrique.

Ao meu pai Paulo por todo suporte, ajuda e incentivo durante minha jornada.

Ao meu irmão Augusto que me ampara em silêncio e me acolhe com seu abraço sempre que preciso.

Ao meu marido Stanley, pela ajuda, amor, acolhimento e paciência com que acompanhou meu percurso.

A minha orientadora, Maria Zilda da Cunha, por todo apoio, por toda liberdade e pelos ricos ensinamentos que me fizeram crescer como pessoa e como pesquisadora.

Às professoras, Fabiana Buitor Carelli e Maria Cristina Xavier de Oliveira, pelas contribuições preciosas que me ofereceram no exame de qualificação.

À Regina Ruiz, Rosmeire Zanfollin, Francisco Bezerra, Márcio Almeida, Andrea Castelaci, Vanessa Desani, Samara Rosolem, Ricardo Ramos, Sandra Figueiredo, Cristina Campos, Valter Nery, Valéria Moreira que me deram a mão quando o caminho se tornava tortuoso.

Em especial, à Nara Rezende e à Gisele Moraes por tudo que sempre fazem, deixando minha vida mais leve, colorida e feliz.

A todos os meus professores, que brilhantemente instigaram minha curiosidade e vontade de aprender.

A Deus, pela paz diária. 


\section{RESUMO}

HOGRAEFE, Renata Paltrinieri. Capitães da Areia, um estudo comparado entre os Amadosliteratura e cinema em diálogo [dissertação]. São Paulo: "Faculdade de Filosofia, Letras e Ciências Humanas", Universidade de São Paulo, 2015, p. 145.

Buscando aproximar as obras literária e fílmica dos Amados, este estudo, sob a perspectiva dos Estudos Comparados, visa abarcar a relação entre estes dois campos narrativos, discutindo como tais obras, através de determinados elementos narrativos, refletem a matéria histórica do contexto em que estão inseridas, bem como marcam o projeto político e estético de seus autores.

Palavras-chave: Literatura, Cinema, Estudos Comparados, Jorge Amado, Cecília Amado. 


\begin{abstract}
HOGRAEFE, Renata Paltrinieri. Capitães da Areia, um estudo comparado entre os Amadosliteratura e cinema em diálogo [dissertação]. São Paulo: "Faculdade de Filosofia, Letras e Ciências Humanas", Universidade de São Paulo, 2015, p. 145.

Seeking to approximate the literary and filmic works of the Amados, this study, from the perspective of Comparative Studies, aims to comprehend the relationship between these two narrative fields, discussing how these works, through defined narrative elements, reflect the historical context to which they belong as well as underline the authors' political and aesthetic projects.
\end{abstract}

Key words: Literature, Cinema, Comparative Studies, Jorge Amado, Cecília Amado. 


\section{Sumário}

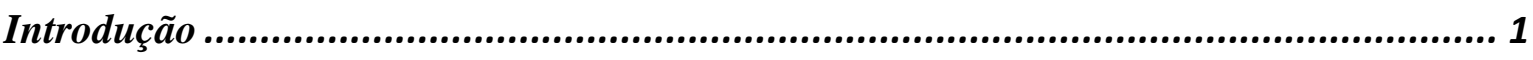

Capítulo 1- $O$ diálogo entre as artes: a literatura e o cinema ...................................... 8

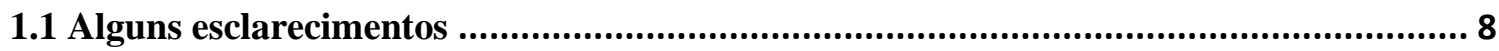

1.2 Breve percurso da Literatura Comparada e alguns princípios dos ECLLP................. 9

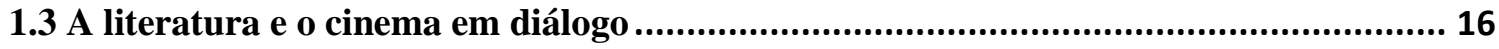

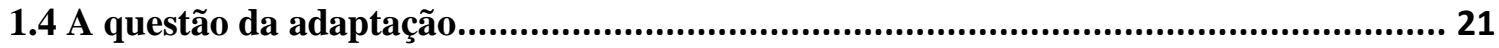

$1.5 \mathrm{O}$ fenômeno artístico dos anos 30 na literatura e no cinema ...................................... 30

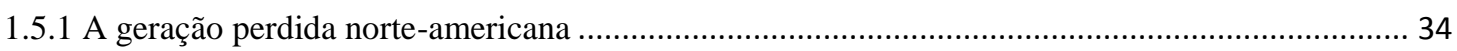

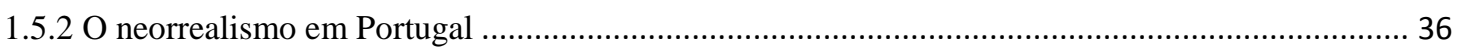

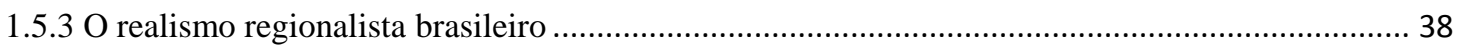

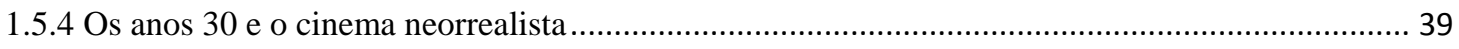

1.5.5 A recepção do neorrealismo pelo cinema brasileiro ........................................................... 41

1.6 As adaptações da obra literária Capitães da Areia ...................................................... 44

Capítulo 2 - As marcas da matéria histórica nos projetos político e estético dos Amados: a

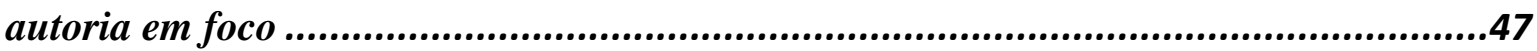

2.1 Contexto histórico de Jorge Amado no momento de produção do romance ................. 47

2.2 A internacionalização de Jorge Amado ...................................................................... 52

2.3 Contexto histórico de Cecília Amado no momento de produção do filme ......................58

2.4 Os projetos político e estético dos autores em Capitães da Areia: a autoria em foco... 61

Capítulo 3 - O diálogo entre os Capitães da Areia dos Amados ...................................66

3.1 Análise comparativa das obras - as escolhas dos autores ...........................................66

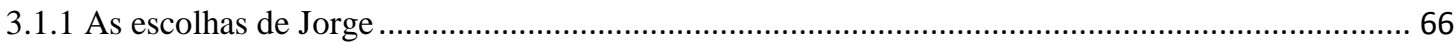

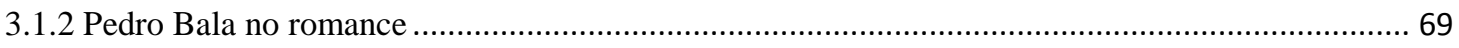

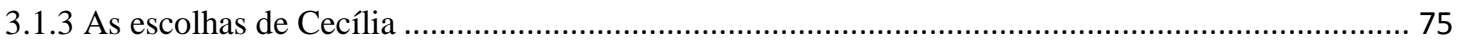

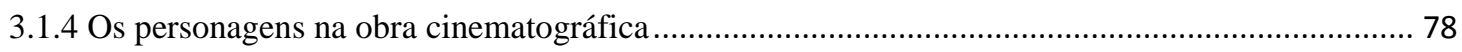

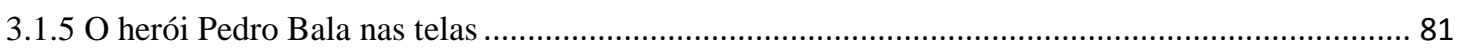

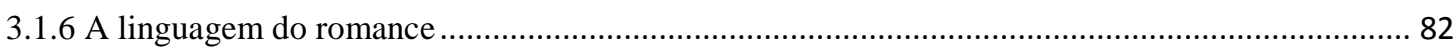

3.1.7 A linguagem dos atores na obra cinematográfica ............................................................. 86

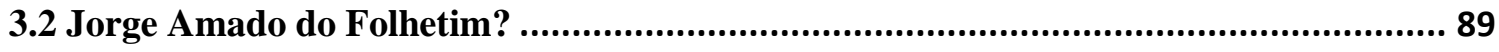

3.3 Cecília Amado e sua aproximação ao cinema clássico hollywoodiano.......................... 96

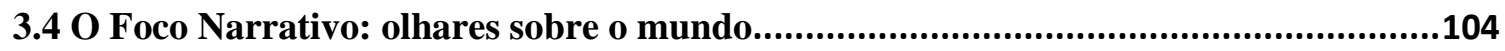

3.4.1 O olhar sobre o mundo nas folhas dos Capitães .................................................................. 106

3.4.2 O olhar sobre o mundo nas telas dos Capitães ................................................................ 112

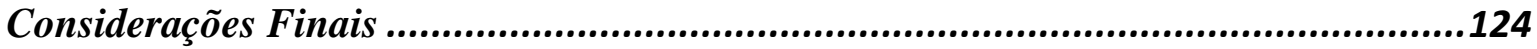

Referências Bibliográficas.................................................................................129 


\section{Introdução}

Na transição do século XX para o século XXI, ocorreram transformações políticas, econômicas, culturais e científico-tecnológicas que puseram em xeque a bipolaridade que dividiu o mundo após a Segunda Guerra Mundial, principalmente, depois da queda de barreiras políticas e econômicas como, por exemplo, a unificação da Alemanha em 1989 e da instituição de grandes blocos como o a União Europeia, Nafta e ALCA. Nesse cenário, houve uma diluição das fronteiras político-econômicas e culturais o que nos leva a um processo de globalização. No entanto, tal globalização ainda coloca algumas nações em posição de destaque em relação a outras.

Além disso, a ideia de globalização - aliada à revolução tecnológica - impulsiona o mundo para um movimento vertiginoso, cuja celeridade pode levar-nos a uma diminuição da reflexão e do diálogo. Por esta razão, o historiador Nicolau Sercenko chama-nos a atenção para o perigo de se tropeçar em um deslumbramento acrítico, quando nos encontramos frente a esse mundo tecnológico:

O surto vertiginoso das transformações tecnológicas não apenas abole a percepção do tempo: ele também escurece as referências do espaço. Foi esse o efeito que levou os técnicos a formular o conceito de globalização, implicando que, pela densa conectividade de toda a rede de comunicações e informações envolvendo o conjunto do planeta, tudo se tornou uma coisa só. Algo assim como um único e gigantesco palco onde os mesmos atores desempenham os mesmos papéis na única peça em que se resume todo o show (...) o fato é que as mudanças tecnológicas, embora causem vários desequilíbrios nas sociedades mais desenvolvidas que as encabeçam, também canalizam para elas os maiores benefícios As demais são arrastadas de roldão nessa torrente, ao custo da desestabilização de suas estruturas e instituições, da exploração predatória de seus recursos naturais e do aprofundamento drástico de suas já graves desigualdades sociais. (SERCENKO, 2001, p. 21)

Ademais, os novos tempos se mostram como tempos em que os indivíduos estão desencantados com as lutas políticas e ideológicas, pois estas se diluíram e seguem sem uma distinção clara entre suas fronteiras, o que leva muitas vezes a uma opção de não exposição de 
posicionamentos. Além disso, é comum que o capitalismo imponha aos indivíduos uma busca pela realização material e pela satisfação de seus desejos individuais, deixando-se de lado as ações coletivas. Essa nova configuração reflete em diversas esferas, inclusive, nas manifestações artísticas que se encontram em um momento complexo em que há uma permeabilidade entre cultura erudita e popular, bem como uma fusão de linguagens causada pela revolução tecnológica, resultando assim em uma hibridização. E, ao mesmo tempo, elementos externos relacionados ao mercado interferem na atividade criadora e no resultado final das manifestações artísticas.

É em meio a esse contexto que esta dissertação se propõe a comparar a obra literária Capitães da Areia e a obra fílmica homônima de 2011, para investigar e problematizar o diálogo que se estabelece entre o projeto político e estético dos Amados e seus tempos históricos, verificando como a matéria histórica do contexto de produção delineia os projetos dos referidos autores.

Sob a perspectiva dos Estudos Comparados, analisaremos as obras levando em consideração o fato de pertencerem a campos narrativos diversos e, portanto, de existirem especificidades na construção de cada narrativa. Para nosso estudo, selecionaremos apenas alguns elementos narrativos, cuja análise possa indiciar aspectos importantes do diálogo que pretendemos perscrutar. Esse estudo abarca questões que decorrem da adaptação, os contextos históricos de cada produção e a distância temporal entre as obras.

Desse modo, um viés dessa investigação enfocará a construção e a trajetória do herói Pedro Bala e a constituição do foco narrativo tanto na obra literária quanto na narrativa fílmica, pois, entendemos que tais elementos narrativos refletem o contexto histórico em que estão inseridas, bem como marcam o projeto político e estético de seus autores. 
No tocante ao filme, verificaremos qual leitura a diretora faz da obra de partida. As escolhas estéticas feitas por ela reverberam qual posicionamento político? Como a obra fílmica reflete o contexto histórico? Como se deu, no processo de recodificação do livro para o filme, a construção do personagem principal Pedro Bala? Como o foco narrativo é construído no filme e qual o desdobramento dele em relação ao espectador? De que forma esse foco narrativo reflete um olhar sobre o mundo? Que olhar é esse? Estas são as perguntas norteadoras deste trabalho, às quais pretendemos responder, buscando depreender como a leitura de uma obra pode contribuir para a interpretação da outra.

Ressaltamos que o estudo levará em conta as especificidades de cada suporte, livro e filme, sem criar uma hierarquia entre eles e nem se prender a critérios de fidelidade, mas estabelecendo, como foi dito, uma relação no âmbito dos Estudos Comparados.

Entendemos, portanto, que o processo de transposição fílmica de uma obra literária deve ser analisado cuidadosamente uma vez que ultrapassa questões referentes aos elementos da narrativa e acaba sofrendo interferências de questões históricas, sociais e até mesmo de ordem econômica que marcam a leitura e as escolhas feitas na elaboração da nova obra. Desta forma, a questão nevrálgica da pesquisa é ultrapassar uma análise formalista dos objetos de estudo e verificar como se fez a releitura de uma obra literária que foi deslocada de seu contexto histórico, bem como analisar como questões externas regem a autoria e conduzem a produção, interferindo no diálogo entre a nova obra e a de origem.

O estudo, aqui proposto, será realizado segundo os pressupostos teóricos dos Estudos Comparados de Literaturas de Língua Portuguesa, destacando os princípios de comparatismo da solidariedade e comunitarismo defendidos por Abdala Jr. Segundo esse crítico, o comparatismo da solidariedade propõe analisar as densas interações entre produções artísticas - sejam elas literárias, cinematográficas, plásticas, musicais etc. - de diferentes culturas e sociedades e em diferentes momentos históricos, contemplando as diferenças com base no 
comunitarismo, ou seja, na formação de um bloco cultural formado pelas chamadas margens não hegemônicas, de forma a propor reflexões críticas a respeitos dessas manifestações culturais. Trata-se, portanto, de comparar as diferenças para que se propiciem embates produtivos e abertos em razão da diversidade cultural e contrapondo-se a um processo de globalização que tende, ao apagar as diferenças, estandardizar as culturas. Sob essa perspectiva, o crítico explica que:

$\mathrm{Na}$ sessão de abertura do IV Congresso ABRALIC, realizado na Universidade de São Paulo, articulado em torno do tema Literatura e diferença, destacamos o fato de que a situação político-cultural que então vivíamos tornava cientificamente importante que nossas pesquisas em literatura enfatizassem suas vinculações supranacionais, como estratégia para fazer face ao vertiginoso processo de estandardização do mercado globalizador. Relevamos, em especial, perspectivas de estudos comparados que contemplassem diferenças com base nos comunitarismos. Explicitamos o fato de que, para nós brasileiros, eram particularmente interessantes estudos voltados para a ampla bacia cultural que nos envolve, contemplando assim os complexos horizontes culturais ibero-afro-americanos. A ênfase no comunitarismo cultural seria, assim, uma das estratégias de estabelecimento de contrafluxos à unilateralidade do processo de americanização do mundo, para nos valer dos modelos de leitura de uma sociedade que se organiza em rede e tende à supranacionalidade (ABDALA JR, 2012b, p. 11).

Assim, essa pesquisa será realizada com base nas perspectivas comparatistas que contemplem as diferenças e, a partir dai, organizem em rede outro tipo de globalização, voltado à solidariedade comunitária.

Sobre esse tema, ensina-nos Cunha que:

[...] O comparatismo da solidariedade, ao qual nos propomos, propicia trocas, circulação de repertórios culturais, em contrapartida a uma globalização unilateral, cuja tendência é apagar diferenças. Lidamos com intersemioses complexas e desafiadoras, com contextos interliterários, interdiscursivos e interdisciplinares. Ao fazê-lo, no confronto com o outro, indagamos sobre nós mesmos, sobre nossa cultura, nossos sonhos, nossas memórias, e as infindáveis maneiras de experenciarmos a trajetória dessa aventura tão humana - tecida de uma intrincada rede de signos - trama de linguagem em que a humanidade vai se construindo em densas e tensas relações, em diferentes momentos históricos, diversas culturas e sociedades ${ }^{1}$.

\footnotetext{
${ }^{1}$ Disponível em: < http://www.simelp2009.uevora.pt/pdf/slt58/05.pdf>. Acesso em: 12 jan 2014.
} 
Sob essa perspectiva, ao aproximarmos comparativamente as duas obras, buscaremos verificar, como já assinalado, as especificidades dos projetos político e estético de cada autor e o faremos sem sobrepor uma obra a outra, sem estabelecer hierarquias, nem entre os autores, nem entre as matérias artísticas de que são feitas as obras (literatura e cinema); na abordagem do diálogo entre os textos, o conceito de intertextualidade desenvolvido por autores como Bakthin e Kristeva será muito caro a esta investigação.

Nesse sentido, discutiremos os fios que tecem em trama dialógica essas duas obras. Para tanto, nos valeremos de obras como Da Narrativa literária e a narrativa fílmica: Amor de Perdição, um exemplo de transcodificação intersemiótica de Maria do Rosário Lupi Bello; Relações Intersemióticas entre o Cinema e a Literatura de Sérgio Paulo Guimarães de Sousa; Crítica à imagem eurocêntrica de Robert Stam; O Discurso Cinematográfico- a opacidade e a transparência de Ismail Xavier, O que é cinema?, de André Bazin; Narration in the fiction film de David Bordweel; Film Adaptation de James Naremore; A sociedade do espetáculo de Guy Debord; A significação do cinema de Christian Metz entre outros.

No primeiro capítulo, traçaremos breve panorama do percurso da Literatura Comparada e dos princípios norteadores da área de Estudos Comparados de Literaturas de Língua Portuguesa, discutiremos a questão das adaptações de obras literárias para obras cinematográficas, passando da discussão sobre a questão da fidelidade para uma focalização no estudo da intertextualidade entre obra fílmica e romance original. Além disso, abordaremos o processo de transposição intersemiótica, sinalizando alguns pontos que podem interferir na sua realização.

Em razão da intrínseca relação existente entre a obra literária em análise e o neorrealismo, contextualizaremos esse movimento estético na literatura norte-americana, brasileira e portuguesa procurando mostrar seus pressupostos político-ideológicos, a situação histórico-cultural específica de cada país e como esse movimento atingiu proporções 
internacionais. Tendo em vista o fato de tal movimento reverberar na obra fílmica que estudamos, uma visada ao desdobramento do neorrealismo no cinema italiano - onde essa corrente artística atingiu seu expoente máximo - e à sua recepção pelo cinema brasileiro foi necessária.

Ainda nesse capítulo, pontuaremos algumas das principais recodificações, para vários suportes, da obra literária Capitães da Areia com o objetivo de reafirmar sua importância cultural tanto o Brasil como em outros países.

Já no segundo capítulo, contextualizaremos historicamente as obras dos Amados a fim de mapear possíveis marcas da matéria histórica nas referidas produções.

Neste, será alvo de atenção: a recepção da obra neorrealista de Jorge Amado, no exterior, sob o ponto de vista de seu ativismo político, observando sua relação com a instauração do neorrealismo português; o diálogo da produção amadiana com a literatura e com movimentos de libertação de alguns países da África de Língua Portuguesa; a recepção da obra de Jorge Amado nos chamados países satélites da União Soviética. O breve estudo tem o intuito de traçar um retrato da importância cultural da criação amadiana para além das fronteiras brasileiras.

Os projetos político e estético dos Amados e seus tempos históricos serão abordados no sentido de verificarmos como a matéria histórica do contexto dinamiza e marca o processo de construção artística dos autores.

O terceiro capítulo desta dissertação reserva-se ao estudo comparativo entre as obras. A via narratológica e semiológica nos possibilitará aqui discutir aspectos da narrativa literária e fílmica, demonstrando nas relações de intertextualidade como a leitura de uma obra ilumina a significação da outra. 
$\mathrm{Na}$ análise da obra literária, procuraremos desvelar aspectos referentes ao projeto de Jorge Amado, de que ideias estava imbuído o autor ao escrever Capitães da Areia e de que forma elas se manifestam na tessitura de seu projeto artístico. Procura-se, então, vislumbrar como isso refletiu política e esteticamente na produção da obra do autor. O comprometimento do escritor com a ideologia do Partido Comunista reverbera na obra em um conjunto de perspectivas e concepções a respeito do futuro do Brasil?

Essas questões sinalizam o estudo da produção de Jorge Amado e nos levam a investigar na transposição fílmica de Capitães da Areia sob direção de sua neta - Cecília Amado - algumas das escolhas feitas pela diretora no momento de recodificação da obra.

Assim, o presente estudo se mostra relevante na medida em que, focalizando sob a perspectiva comparatista a relação entre literatura e cinema, mostra como esse diálogo entre as artes contribui para a concepção das obras como objeto de representação de seus contextos históricos e como os discursos e formas que apresentam são marcados por matizações de ordem política. 
Capítulo 1- O diálogo entre as artes: a literatura e o cinema

\subsection{Alguns esclarecimentos}

Antes de focalizarmos os objetos de estudo da pesquisa, faz-se necessário discutir algumas questões que irão nortear o percurso deste estudo.

Primeiramente, tendo em vista as peculiaridades dos projetos político, estético e ideológico dos Amados e, por este estudo estar inserido na área de Estudos Comparados de Literaturas de Língua Portuguesa, consideramos relevante traçar um breve percurso da Literatura Comparada para alcançar o conhecimento do aparato teórico, base desta pesquisa, e delimitar o posicionamento metodológico que iremos adotar no prosseguimento do trabalho.

Também entendemos ser importante discutir a relação dialógica que se estabeleceu entre literatura e cinema através do caráter narrativo dessas duas vertentes artísticas, bem como tecer algumas considerações a respeito do processo de adaptação fílmica, discorrendo sobre os diferentes posicionamentos da crítica e, também, sobre a complexidade e as questões que esse processo envolve para que tais pontos sejam levados em consideração durante a realização da pesquisa.

Outra questão que se apresentou crucial foi a análise dos movimentos artísticos dos anos 30 tanto na literatura brasileira quanto em outras literaturas, como é o caso da americana, que estabeleceram um rico diálogo com a brasileira. O objetivo de tal abordagem é traçar a dimensão dessas manifestações artísticas, bem como o diálogo que se estabeleceu entre diferentes culturas e, no caso de Portugal, como houve uma mudança da direção de contato uma vez que, através da literatura amadiana, o Brasil passa a ser referência para a literatura portuguesa e não o contrário. Além disso, esse fenômeno artístico, bem como as obras que dele resultaram, só pode ser compreendido pela carga política e ideológica que carrega em si. 
Assim, para se analisar a obra literária Capitães da Areia, é essencial que se entendam as nuances dos movimentos artísticos de 30.

Como a obra fílmica apresenta alguns aspectos do neorrealismo italiano, entendemos ser relevante descrever, em linhas gerais, como se deu o diálogo entre o cinema brasileiro e esse movimento. Ressalta-se que não pretendemos afirmar que o filme dirigido por Cecília Amado se insere nessa estética uma vez que o cinema neorrealista é uma manifestação cultural específica de um dado contexto histórico e somente as obras pertencentes a este momento podem ser classificadas como tal. No entanto, por ter um posicionamento político que sugere um engajamento social, a obra fílmica de 2011 dialoga com aquele movimento já que o filme tenta mostrar a realidade dos meninos de rua através de uma estética que carrega alguns traços do movimento estético do neorrealismo.

Ao final, discutiremos as possíveis leituras da obra Capitães da Areia e os inúmeros processos de recodificação aos quais a obra foi submetida com o intuito de se demonstrar o peso cultural que tal obra exerce tanto na cultura brasileira como em outras culturas e que essa importância cultural vem se consolidado com o passar dos anos, tornando a obra, ainda hoje, atual.

\subsection{Breve percurso da Literatura Comparada e alguns princípios dos ECLLP}

Esta pesquisa foi desenvolvida na perspectiva dos Estudos Comparados de Literaturas de Língua Portuguesa que podem ser considerados uma ramificação da Literatura Comparada.

Como sabemos, a atividade comparativa é inerente ao ser humano e, portanto, bastou o nascimento das literaturas grega e romana para que a Literatura Comparada surgisse.

Para Carvalhal (1999, p.6), “comparar é um procedimento que faz parte da estrutura 
do pensamento do homem e da organização da cultura. Por isso, valer-se da comparação é hábito generalizado em diferentes áreas do saber humano."

No entanto, apenas no século XVIII, a Literatura Comparada começou a apresentar seus primeiros contornos e, somente no século XIX, foi sistematizada como disciplina em um contexto europeu. Seus princípios norteadores eram fundados na ideia de fonte e influência, ou seja, elegia-se uma obra de uma literatura considerada maior como objeto de estudo e tentava-se demonstrar sua superioridade sobre outras consideradas menores. Dessa forma, através de um juízo valorativo, buscava-se comprovar uma forte dependência cultural de uma obra em relação à outra, como se houvesse uma literatura pura que funcionasse como verdadeiro modelo ou fonte para as chamadas literaturas menores as quais se limitariam a um papel secundário, de integração de influências advindas das "fontes".

Tal posicionamento fez com que a Literatura Comparada estabelecesse um forte elo com o nacionalismo, fazendo com que seus estudos perscrutassem relações de submissão cultural.

Cada vez mais, buscava-se estudar a literatura estrangeira e a recorrência desses estudos fez com que, no século XIX, vários intelectuais europeus se reunissem para discutir essa nova prática. Neste contexto, Abel Villemain, Jean-Jacques Ampère e Philarète Chasles criaram a Literatura Comparada como disciplina integrante do currículo das universidades francesas, ainda sob a concepção do binômio fonte e influência.

Em 1931, Paul Van Tieghem laçou o livro La littérature comparée em que, de acordo com Carvalhal (1999), sistematiza princípios e formas de atuação dos comparatistas. Ademais, esforça-se em distinguir a Literatura Comparada de literatura geral, conferindo a esta última um caráter mais global enquanto a Literatura Comparada manteria um caráter mais específico, embora ambas mantivessem o estatuto de disciplinas históricas. 
Tecendo crítica mais direta a respeito do conceito de influência e a crença na superioridade da literatura de países da Europa Ocidental, René Etimble (CARVALHAL, 1999) condena a postura nacionalista da Literatura Comparada estabelecida pela escola francesa e defende uma concepção "planetária" do literário. Ele adota uma visão mais descentralizadora uma vez que inclui literaturas não europeias no âmbito da Literatura Comparada, valorizando as especificidades de cada cultura. Além disso, critica a hegemonia de países europeus como França e Inglaterra, conferindo importância às chamadas "pequenas literaturas" uma vez que, para ele, qualquer literatura pode influenciar ou ser influenciada.

Em 1968, Claude Pichois e André M. Rousseau (apud CARVALHAL; COUTINHO, 1994) publicam um manual de Literatura Comparada, traçando a história da tal disciplina por meio de uma visão mais ampla, mas que ainda privilegia analogias e relação de parentesco e filiação.

A hegemonia francesa acerca dos estudos comparatistas começa a ruir com a realização do $2^{\circ}$ Congresso da Associação Internacional de Literatura Comparada, realizado em Chapel Hill, EUA. Nesse congresso, René Wellek afirma que os franceses falharam por não estabelecer um objeto de estudo e uma metodologia próprios da Literatura Comparada. Também questiona o esforço de Van Tieghem de diferenciar a Literatura Comparada da Literatura Geral.

Segundo Wellek,

[...] A tentativa de restringir a "literatura comparada" a um estudo de "comércio exterior" entre literaturas é certamente infeliz. A literatura comparada seria, em seu objeto de estudo, um conjunto incoerente de fragmentos não relacionados: uma rede de relações constantemente interrompidas e separadas dos conjuntos significativos. O comparatista qua comparatista, neste sentido limitado, só poderia estudar fontes e influências, causas e efeitos, e seria impedido, até mesmo, de investigar uma única obra de arte em sua totalidade, uma vez que nenhuma obra pode ser inteiramente reduzida a influências externas ou considerada um ponto irradiador de influência sobre países estrangeiros apenas." (apud CARVALHAL; COUTINHO, 1994, p. 109). 
Influenciado pelo Formalismo Russo, pela Fenomenologia e pelo New Cristicism, Wellek busca um equilíbrio entre a análise crítica do texto e seu elemento histórico, criticando o estudo de fonte e influência ao propor uma análise voltada ao texto, sem prescindir a relação entre texto e contexto.

Já Remak (apud CARVALHAL; COUTINHO, 1994) amplia a definição de Literatura Comparada, defendida pela escola francesa ao propor uma variedade de abordagem, deixando de lado métodos rigorosamente históricos e implantando o conceito de interdisciplinaridade ao considerar, além do estudo comparado entre obras literárias, o estudo das relações entre literatura e outras artes. Além disso, passou-se a considerar a admissão de estudos comparativos entre autores de uma mesma literatura nacional.

Outro estudioso importante para a Literatura Comparada foi Claudio Guillen. De origem espanhola, mas radicado nos Estados Unidos por muitos anos, Guillen propôs uma ampliação nos estudos comparatistas ao analisar obras de diferentes procedências. No mais, afirmava que a concepção de influência devia ser entendida em uma perspectiva estética, "entendendo-a como um fator esclarecedor do processo criativo" (CARVALHAL, 1999, p.17).

Também criticando métodos comparatistas baseados nas influências literárias que não levavam em conta fatores importantes como processo criativo do autor, o contexto social da obra entre outros, estudiosos do Leste Europeu ganham a cena. Victor M. Zhirmunsky, por exemplo, passou a considerar fatos literários independentemente de sua gênese e de seu contexto histórico, encarando a literatura a partir de um sistema de analogias tipológicas.

No contexto da América Latina, também temos importantes contribuições de estudiosos para a Literatura Comparada. O uruguaio Ángel Rama (apud NITRINI, 1998, p. 71), defendia uma visão única e global de literatura através de um aparato crítico que 
unificasse todas as literaturas latino-americanas a fim de substituir o método historiográfico europeu. Já Ana Pizarro acreditava em um trabalho fundado na estrutura literária inserida em um contexto histórico e dinâmico.

Antonio Candido (apud Nitrini, 1998), por sua vez, desponta como o principal formulador de um modelo comparatista dialético adequado à leitura da literatura brasileira cuja contribuição não se limita à delimitação do campo teórico no Brasil uma vez que formula um conjunto de orientações importantes para o comparatismo mundial.

No meio dessa trança de conceitos, a Literatura Comparada atual se adequou às transformações e abriu espaço para as mais diferentes culturas que foram caladas por muito tempo em razão à hegemonia dos países europeus ocidentais.

No que se refere aos Estudos Comparados de Literaturas de Língua Portuguesa, eles se originam da Literatura Comparada, mas não se restringem a ela. Eles ampliam-se na medida em que buscam estudar interdisciplinar e comparativamente as literaturas produzidas em Língua Portuguesa nos mais diversos contextos sociopolíticos e culturais dos países que têm a Língua Portuguesa como idioma oficial e que, por vezes, comungam do mesmo legado histórico fundado no colonialismo.

Ademais, os Estudos Comparados desenvolvem pesquisas de produções culturais de Língua Portuguesa, não só observando as intrínsecas relações que estas estabelecem entre si, mas também preservando e respeitando suas especificidades. Abrangem, portanto, não somente os diálogos e as articulações mais profundas entre tais produções, mas também o diálogo e correlações entre elas e outras áreas do conhecimento ou outras artes.

De acordo com Abdala Jr. (2007, p. 29 e 30),

[...] Em relação aos estudos comparados, nos limites da língua portuguesa, tratava-se de verificar, por exemplo, o que existia da cultura portuguesa ou dos países africanos na literatura do Brasil; da cultura do Brasil e de Portugal 
nas literaturas africanas de língua portuguesa. Há um diálogo embutido nas formas literárias que circulam entre os países de língua portuguesa [...].

E a literatura comparada, nesta perspectiva, mais do que o estudos de dois ou mais escritores de diferentes literaturas, dois ou mais textos dispostos lado a lado, se mostra campo fértil para a discussão de uma questão mais crítica, mais abrangente que envolve duas culturas. Com o procedimento, partindo da literatura, poderíamos ainda imbricar suas formulações discursivas e do imaginário, discursos de outras áreas do conhecimento e de outros campos artísticos. A busca da especificidade conflui assim para a concepção da heterogeneidade constitutiva, malhas discursivas, também elas tendentes ao rompimento de fronteiras estáticas. (ABDALA JR, 2007, p. 29 e 30).

É importante salientar que os estudos comparados de produções culturais de diferentes povos constituem um instrumento essencial para a compreensão do "outro" e do "eu" nacional. E o processo de conhecimento do "eu" e do "outro", nesse intercâmbio cultural, implica em conhecer o "outro" mas, sobretudo, na comparação do "eu" com aquilo que se nota no "outro".

De acordo com Santilli (2003), a finalidade do estudioso da área, em nível individual é buscar na literatura o autorreconhecimento e, no plano social, abraçar a alteridade. Desta forma, o diálogo entre as produções culturais levará cada povo que comunga da Língua Portuguesa a conhecer suas peculiaridades e as dos outros.

Como vimos, já não é imprescindível que os Estudos Comparados fiquem restritos a uma comparação de texto a texto. Eles podem e devem ultrapassar os limites da literalidade e se aprofundar nas relações que as produções estabelecem com outros textos, outras linguagens, outras áreas do conhecimento, o que é extremamente importante para despertar a reflexão crítica dos sujeitos de um dado momento histórico.

Desta forma, a intenção desta pesquisa de comparar a narrativa literária Capitães da Areia, do autor Jorge Amado, e a narrativa fílmica homônima de 2011, dirigida por Cecília Amado, insere-se na perspectiva e nos princípios dos Estudos Comparados de Literaturas de Língua Portuguesa. 
Sobre esse aspecto, posiciona-se Nitrini (1998, p. 259):

[...] Nos dias atuais, o estudo de relações entre literatura e outras artes já tem seu lugar garantido no domínio da literatura comparada. Se folhearmos os mais recentes manuais e livros teóricos de literatura comparada, inclusive os de tradição francesa, sempre encontraremos um capítulo ou pelo menos um item dedicado a essa questão. Vale lembrar que sua inclusão o como a objeto da literatura comparada decorreu do questionamento de que foi alvo a escola francesa nos anos 50 .

Nesse sentido, além de haver estudos que reiterem o valor do diálogo das literaturas na construção do conhecimento, eles são importantes por possibilitar análises mais ricas e amplas das diferentes expressões artísticas ao estender o estudo da literatura a outras áreas da expressão humana. Assim, os Estudos Comparados propõem uma ampliação dos campos da atividade crítica e das Ciências Humanas por meio da chamada interdisciplinaridade.

E é em meio a esse espírito interdisciplinar que nos valeremos do arcabouço teórico e metodológico da Literatura Comparada para realizar a análise da obra literária juvenil Capitães da Areia de Jorge Amado e da obra fílmica homônima de Cecília Amado, sob uma perspectiva ampla, interdisciplinar, intertextual e solidária que nos permita verificar como uma obra ilumina a outra, pautando-nos principalmente nos princípios norteadores dos Estudos Comparados.

Assim, este estudo será conduzido pelo princípio da interdisciplinaridade cuja amplitude abarcará não apenas análises literárias de Língua Portuguesa, como também a relação entre literatura e cinema, conferindo a estas áreas a mesma equivalência.

Em razão de os Estudos Comparados considerarem a literatura uma área de conhecimento em estrita correspondência com outras do campo das humanidades, este trabalho também buscará se configurar como uma resposta político-cultural que parte do princípio de que a literatura é uma área do conhecimento válida e em intrínseco diálogo com outras de áreas. 
Assim, as produções artísticas que formam o corpus desse trabalho serão analisadas sob o prisma da intertextualidade, configurando-se como uma trama de linguagens, resultado de outros textos. De acordo com Abdala Jr. (2007, p. 109), os estudos comparados entendem intertextualidade como um processo de "incorporação cultural, quase sempre não consciente, de outros textos (ou formas) da tradição artística".

Vale lembrar que, além dos princípios destacados acima, essa pesquisa considerará as perspectivas comparatistas que revelem não apenas as similaridades e diferenças entre as obras literária e fílmica, como também a forma que uma ilumina a outra, possibilitando ao leitor penetrar nos textos e encontrar ressonâncias entre elas.

\subsection{A literatura e o cinema em diálogo}

Segundo Roland Barthes (1972, p.19-20),

[...] Inumeráveis são as narrativas do mundo. Há em primeiro lugar uma variedade prodigiosa de gêneros, distribuídos entre substâncias diferentes, como se toda matéria fosse boa para que o homem lhe confiasse suas narrativas: a narrativa pode ser sustentada pela linguagem articulada, oral ou escrita, pela imagem, fixa ou móvel, pelo gesto ou pela mistura ordenada de todas essas substâncias; está presente no mito, na lenda (...) na pintura, no vitral, no cinema, nas histórias em quadrinhos, no fait divers, na conversação. Além disso, sob essas formas quase infinitas, a narrativa está presente em todos os tempos, em todos os lugares, em todas as sociedades $[\ldots]$.

A narrativa nasce da necessidade de o homem se comunicar, de narrar suas experiências, de contar algo sobre uma situação inusitada, de compartilhar o que é fruto de sua imaginação. Portanto, pode-se dizer que o ato de narrar se origina com a humanidade, é algo inerente à vivência humana e, apesar de ter sofrido inúmeras transformações, continua relacionado diretamente com as estratégias imaginativas, com as manifestações existenciais, com as produções culturais, com as relações sociais e políticas do homem, sendo, assim, uma prática fundamental do viver humano. 
Inicialmente, a noção de narrativa se relacionava a um território essencialmente literário. Entretanto, tal concepção foi sendo ampliada, chegando a abarcar diferentes searas do universo humano. Conforme Bello (2008, p.41 e 42):

[...] à medida que os traços fundamentais da narrativa foram se tornando mais claros e precisos, foi sendo possível detectá-los em quase todas as áreas da vida humana, desde a arte à vida do dia-a-dia, ao trabalho dos historiadores, psicólogos, educadores, jornalistas, advogados etc. Tornou-se claro que a narrativa não era nada a menos do que um dos modos fundamentais usados pelos seres humanos para pensar acerca do mundo e não podia ser confinada ao meramente ficcional. O objetivo dos estudos narratológicos evoluiu de uma preocupação essencialmente descritiva e objetiva para a análise das condições da sua produção e da sua recepção, numa perspectiva que, a partir dos anos setenta, passou a valorizar a narrativa como processo de comunicação.

Dessa forma, sob a perspectiva dos estudos narratológicos, a narrativa é um texto que apresenta uma história constituída por uma sequência de eventos que se desenrolam em um tempo e espaço, através de um ou mais pontos de vista. Delimitada por um começo e um fim, pressupõe a existência de um autor. É um discurso, possível de ser veiculado por diversos meios.

Retomando Barthes (1972, p.19-20),

[...] pode ser sustentada pela linguagem articulada, oral ou escrita, pela imagem, fixa ou móvel, pelo gesto ou pela mistura ordenada de todas essas substâncias; está presente no mito, na lenda [...] na pintura, no vitral, no cinema, nas histórias em quadrinhos, no fait divers, na conversação. (BARTHES, 1972, p.19-20)

Bello (2008, p. 75), ao abordar questões que relacionam narrativa literária à narrativa fílmica, faz referência a vários críticos, entre os quais, Cristian Metz, Northrop Frye e Aguiar e Silva, e afirma que.

[...] o cinema, pela sua capacidade de traduzir a realidade do universo físico, captando todos os seus elementos através da sua particular aptidão para a iconicidade, estabelece frequentemente com o real uma relação profunda do tipo narrativo. 
Para Xavier (1997), a narrativa pode ser considerada como uma prática discursiva comum tanto à literatura quanto ao cinema, uma vez que muitas noções já consolidadas pela tradição da teoria literária foram incorporadas pelos estudos cinematográficos. Por este viés, pode-se considerar o fato de que o Cinema e a Literatura apresentarem pontos de contatos por serem artes narrativas, então, é natural que se estabeleça um diálogo entre as duas artes para, através de trocas, impulsionarem seus respectivos desenvolvimentos.

Sobre isso, Epstein. no ensaio O cinema e as letras modernas de 1921, já apontava a estreita relação que a literatura e o cinema estabelecem ao afirmar que "a literatura está saturada de cinema. Reciprocamente, esta arte misteriosa muito assimilou da literatura" (EPSTEIN, 1991, p.269). De acordo com o crítico, não é somente o cinema que busca elementos na literatura como esta também vem se espelhando nas estruturas do cinema. Dessa forma, a relação entre essas duas artes é, na verdade, uma via de mão-dupla. São muitos pontos de convergência entre eles, mesmo que a base da literatura seja a expressão verbal enquanto que a imagem visual e o movimento constituam a matéria básica do cinema.

Em perspectiva semelhante, Sousa (2001, p.15-16) afirma que:

[...] Interessa-nos, com esse estudo, focar o relacionamento intersemiótico operado entre duas artes (literatura e cinema) que mantém entre si um elevado grau de afinidade transestética, por partilharem uma matéria de expressão comum (o signo verbal); por consistirem ambas na representação de uma sucessividade de acontecimentos distribuídos num tempo-espaço e por disporem de estruturas enunciativas (dimensão narrativa). Trata-se do texto fílmico e do texto literário, domínios estético-expressivos de natureza e perfil semiológico distintos, mas têm manifestado, desde os primórdios da sétima arte, uma fértil ligação, interseccionado criativamente formas e conteúdos.

No tocante à literatura, não se pode negar que ela, desde os primórdios do cinema, tem sido o ponto de partida para muitos filmes. Na obra A Theory of Adaptation, Hutcheon (2006) apresenta uma série de estatísticas (do ano de 1992) quanto à adaptação de obras 
literárias para obras fílmicas. De acordo com a autora, $85 \%$ de todos os vencedores do Oscar de melhor filme, $95 \%$ das minisséries e $70 \%$ dos filmes premiados no Emmy são adaptações.

Assim, ao se dar conta da sua capacidade narrativa, o cinema viu na literatura uma fonte inesgotável de contar histórias. E, a partir do momento que o cinema passa a contar histórias, ele estreita seu diálogo com a literatura e ambos passam a comungar de muitos elementos, conforme destaca Xavier (2005, p.33):

[...] Na sua organização geral, o espaço-tempo constituído pelas imagens e sons estará obedecendo a leis que regulam modalidades narrativas que podem ser encontradas no cinema ou na literatura. A seleção e disposição dos fatos, o conjunto de procedimentos usados para unir uma situação à outra, as elipses, a manipulação das fontes de informação, todas essas são tarefas comuns ao escritor e ao cineasta.

Apesar de apresentar pontos e procedimentos em comuns, é importante destacar que cada uma das artes possui uma linguagem com elementos próprios e são esses que estabelecem as importantes diferenças entre elas:

O fato de um ser realizado através da mobilização de material linguístico e de outro ser concretizado em um tipo específico de imagem introduz todas as diferenças que separam a literatura do cinema. (XAVIER, 2005, p. 33).

Em razão das proximidades, e também das especificidades dessas expressões artísticas, o diálogo entre elas se torna complexo e mais rico, envolvendo questões que vão além da problemática da adaptação. Ao estudar literatura e cinema, deve-se atentar, portanto, para as especificidades discursivas de cada arte, para a contextualização sociocultural e histórica das obras, para a liberdade criativa de seus realizadores, para a intertextualidade que permeia as produções, para a troca que se estabelece entre essas duas manifestações artísticas em termos conceituais, estéticos, temáticos e procedimentais e para os projetos estético e político de seus autores. 
Dessa maneira, será possível compreender e admitir os reflexos, ressonâncias e intersecções que permeiam o diálogo entre literatura e cinema. As fronteiras dessas artes abrangem, assim, uma extensão bem mais ampla que os limites estreitos impostos pela questão da adaptação.

Nessa ordem de ideias, vale ressaltar que se a intenção inicial deste estudo era comparar as obras literária e fílmica dos Amados pela semelhança entre seus componentes estruturais, conforme o exposto acima, percebe-se que um estudo estritamente formalista se revela limitado, em especial, se atentarmos para o fato de se tratar de obras pertencentes a contextos históricos diferentes e que, portanto, trazem vozes e discursos diversos.

A questão da adaptação fílmica de uma obra literária envolve elementos, além dos estruturais, que se relacionam diretamente com questões culturais, históricas e sociais. Desse modo, importa ressaltar que a presente pesquisa parte do estudo de elementos da narrativa para ir além, isto é, visa a verificar como elementos do contexto social, externos à narrativa ficcional, engendram a obra literária e dinamizam o diálogo da literatura com outra forma de expressão artística, constituindo um estudo interdisciplinar rico em contrastes e nuances.

Para tanto, buscamos aproximar as obras pelo princípio da intertextualidade desenvolvido por Kristeva (1974). Segundo esse conceito, a intertextualidade engloba as relações do texto com o sujeito, o inconsciente e a ideologia numa perspectiva dialógica. A partir de tal conceito, passou-se a pensar na especificidade do literário através de um diálogo interdiscursivo, por meio de estratégias de aproximação e de confronto de textos e discursos.

É interessante apontar que 'intertextualidade' é um termo cunhado por Kristeva a partir das reflexões bakhtinianas de dialogismo e polifonia. Todo texto se constrói como uma multiplicidade de vozes sociais. Ainda segundo a autora, a palavra literária não apresenta um 
sentido fixo, mas representa uma trama de superfícies textuais, um diálogo de diversas escrituras: do escritor, do leitor e do contexto cultural.

Em suas palavras, "todo texto é absorção e transformação de outro texto" (Kristeva, 1974, p. 64). Portanto, o texto literário não se esgota em si mesmo, e sim se multiplica e projeta-se em outros textos.

De acordo com Carvalhal (2006, p.127), para Kristeva,

[...] "em lugar da noção de intersubjetividade se instala a de intertextualidade e a linguagem poética se lê, ao menos, como dupla". A teoria do texto se fundamenta logo em três grandes premissas: a primeira, "que a linguagem poética é a única infinitude do código", depois, que o texto literário é duplo: "escrita/leitura" e, finalmente, que o texto literário é "um feixe de conexões". Isto posto, temos o texto como "diálogo de várias escrituras", e o que era antes entendido numa relação individual (intersubjetiva) passa a ser coletivizado, ou seja, as relações são estabelecidas no conjunto dos textos. Desse modo, o texto ressalta sua natureza heterotextual, sendo penetrado de alteridade, constituído de outras palavras além das próprias.

A análise comparativa proposta em nosso estudo sobre as obras dos Amados fundamenta-se nas noções previamente citadas e comentadas a respeito da Literatura Comparada, bem como no conceito de intertextualidade, tão caro aos pressupostos dos estudos comparados de literatura, como uma importante ferramenta teórica que preconiza que as obras literária e fílmica se complementam e se interrelacionam.

\subsection{A questão da adaptação}

A prática da adaptação de filme a partir de um texto literário é quase tão antiga quanto a máquina do próprio cinema. Desde seu início, a fonte escrita mais popular as adaptações foi o romance. Ao mesmo tempo em que as adaptações ocupam um lugar especial na história do cinema, a crítica, interessada no modo como as duas linguagens dialogam, 
também tem se dedicado cada vez mais à sistematização dos estudos desse processo de recodificação.

Os estudos sobre adaptação fílmica de obra literária fizeram um longo percurso até alcançar o posicionamento atual. Nos primeiros estudos sistematizados sobre essa questão, era comum o romance ocupar um lugar de destaque e a crítica assumir uma opinião conservadora ao afirmar que, de alguma forma, o filme havia violado a obra literária.

A linguagem convencional da crítica sobre as adaptações tem sido, com frequência, profundamente moralista, rica em termos que sugerem que o cinema, de alguma forma, fez um desserviço à literatura [...]

Com demasiada frequência, o discurso sobre adaptação sutilmente reinscreve a superioridade axiomática da literatura sobre o cinema (STAM, 2006, p.19)

Bazin, na década de 40, foi um dos pioneiros ao apresentar uma visão que se diferenciava dessa corrente. Ele inova ao considerar a adaptação como forma de leitura de uma obra literária ou, em suas palavras, como digest. Para ele, a contribuição da adaptação é tornar as grandes obras da literatura conhecidas pelas grandes massas, muitas vezes, pouco letradas. Assim, a adaptação seria uma forma de democratização da cultura. (BAZIN, in NAREMORE, 2000).

Em 1957, George Bluestone publica o livro Novels into Film: the metamorphosis of fiction into cinema, considerada uma das primeiras obras teóricas sobre o tema em questão. Nela, o autor discute sistematicamente a adaptação, partindo de algumas obras canônicas, tais como: Orgulho e Preconceito, Madame Bovary, Morro dos Ventos Uivantes e Vinhas da Ira e de suas adaptações para o cinema. Ele ainda alega que alguns casos de adaptação não desvirtuam as obras literárias de partida já que partem delas para produzirem um novo trabalho artístico que, necessariamente, será diferente em razão das próprias características do cinema. 
Embora Bluestone ainda confira um peso maior aos textos de partida, ele procura demonstrar a irrelevância de se analisar a adaptação a partir da noção de fidelidade. Para ele, não se deve categorizar os filmes em fiéis ou infiéis mas, sim, em filmes bem-sucedidos ou malsucedidos. No mais, ele é um dos primeiros teóricos do cinema a afirmar que, quando se estuda adaptação, deve-se levar em conta aspectos como bilheteria, produção, público-alvo e popularização de obras literárias canônicas.

Neste livro, Bluestone argumenta que alguns filmes (seus exemplos são todos de Hollywood, incluindo O Delator, Morro dos Ventos Uivantes e As Vinhas da Ira) não diminuem sua fonte literária; ao invés, eles metamorfoseiam romances em outro meio que possui suas possibilidades formais e narratológicas próprias [...].

Ao mesmo tempo, seu assunto de interesse e sua completa abordagem tendem a confirmar a prioridade intelectual e a superioridade formal dos romances canônicos, que provêm os filmes que ele discute com suas fontes, e com um valor padrão com o qual seu sucesso ou fracasso é mesurado. (apud NAREMORE, 2000, p. 06, tradução nossa).

Nas décadas de 60 e 70, os estudos estruturalistas e pós-estruturalistas começam a questionar esse posicionamento da crítica ao considerar "todas as práticas de significação como sistemas compartilhados de sinais que produzem textos dignos do mesmo escrutínio cuidadoso dos literários, abolindo, desta forma, a hierarquia entre o romance e o filme." (STAM, 2006, p.21).

Percebe-se, pelas correntes pós-estruturalistas, que é necessário ir além dos limites do texto e de sua forma com o que se passa a considerar, de um modo interdisciplinar, outros aspectos, tais como: contexto de produção e a recepção.

A partir desse novo posicionamento, várias outras correntes - a teoria da recepção, os estudos culturais, o multiculturalismo, pós-colonialismo entre outras - contribuíram para a refutação de vários preconceitos em relação à adaptação, rejeitando conceitos que preconizavam a fidelidade e criavam uma hierarquia entre o chamado texto original e sua “cópia”. A adaptação começa a ser vista como uma nova produção cultural. 
Deste modo, as mais recentes teorias da adaptação, voltadas para a superação do discurso da fidelidade, apresentam uma perspectiva mais ampla que envolve tanto os elementos internos das obras quanto os externos, verificando o diálogo que elas estabelecem. Por essa nova abordagem, faz-se uma leitura interpretativa das produções culturais no movimento dos vários agentes produtores, realizadores e exibidores, englobando também as relações estéticas através das quais as obras artísticas representam em cada meio (literário ou fílmico) uma dada realidade sociocultural.

Seguindo essa perspectiva, Metz (1972), ao estudar o sistema semiótico do cinema, afirma que tanto o cinema quanto a literatura contam histórias, entretanto, eles são diferentes, pois, cada um tem suas peculiaridades: sua própria sintaxe, seus símbolos, sua linguagem, suas possibilidades criativas. E, apesar de as imagens terem o poder de dizer assim como as palavras, elas o fazem de modo diferente. Desta forma, não é possível se equiparar imagem e texto verbal o que implica tanto possibilidade quanto na necessidade das adaptações.

Já para o estudioso Dudlley Andrew, “[...] a adaptação é, em grande medida, a apropriação do significado de um texto prévio" (apud BELLO, 2011, p. 174) e aponta como característica distintiva da adaptação, a equiparação do sistema semiótico do cinema a uma realização anterior de outra natureza. Isto é, no caso da adaptação de livros para filmes, os sistemas de significação presentes na linguagem literária são levados a produções de características próprias do cinema.

Afirma a importância de situá-la sempre dentro de outro sistema de signos, já que opera com combinações de diferentes sistemas que vão ao encontro de nossas associações. O teórico postula que “[...] cada trabalho de arte é um construto de elementos construídos a partir de um uso tradicional de um sistema" e acrescenta que "[...] signos verbais e 
cinematográficos compartilham um destino comum: serem condenados à conotação ${ }^{3 \%}$; por isso, na ficção," [...] cada significante identifica um significado, mas também explicita uma cadeia de reações para outras relações que permite a elaboração do mundo ficcional ${ }^{4}$ " (ANDREW apud NAREMORE, 200, p. 29-30, tradução nossa).

Andrew valida, de certa forma, a adaptação e a considera como uma arte independente da obra original. No mais, ele sistematizou três formas de adaptação: empréstimos, interseção e fidelidade e transposição.

Empréstimo é um dos modos mais utilizado de adaptação já que o adaptador utiliza como obra de partida um livro clássico. De acordo com Andrew, nesta situação, o adaptador espera ganhar credibilidade por seu trabalho com o prestígio de uma obra canônica. Mas, ao mesmo tempo, essa prática funciona como uma forma de levar o público a ver o seu trabalho. Ao estudar este modo de adaptação, deve-se procurar a fonte do poder no original, bem como observar como o adaptador fez uso desse poder para produzir sua adaptação.

Já na intersecção, a relação entre filme e livro adaptado se estabelece na tentativa de transmitir o original pela linguagem do cinema através de um processo de refração, não de adaptação.

Como descreve Andrew (apud NAREMORE, 200, p. 31, tradução nossa):

[...] todos esses trabalhos temem ou se negam a adaptar. Ao invés, eles apresentam a alteridade e a distinção do texto original, iniciando um intertexto dialético entre as formas estéticas de um período e as formas cinematográficas do nosso próprio período"

E, por fim, o crítico estabelece a forma de adaptação "fidelidade e transposição" pela qual a recodificação buscaria constantemente reproduzir através do cinema uma característica

3 "[...] verbal and cinematic signs share a common fate: that of being condemned to connotation."

4 “[...] every signifier identifies a signified, but also elicits a chain of reaction of others relations that permits the elaboration of the fictional world."

5 "All such works fear or refuse to adapt. Instead they present the otherness and distinctiveness of the original text, initiating a dialectical interplay between the aesthetic form period and the cinematic forms of our own period [...]". 
ou peculiaridade essencial da obra de partida. Nessa forma de adaptação, o adaptador pode recriar em sua linguagem as categorias narratológicas ou tentar manter ao "espírito" do original, utilizando equivalentes da linguagem cinematográfica. Para ele, essas formas de adaptação e as estratégias estilísticas usadas para atingir essas equivalências são reflexos de seu contexto de enunciação e podem ser uma fonte de estudo de sua época.

Outro crítico que se destacou por pensar a questão da adaptação foi Brian McFarlane. Em sua teoria, McFarlane (apud BELLO, 2011, p. 145) define a adaptação fílmica como um processo de tradução intersemiótica entre dois sistemas (a literatura e o cinema, por exemplo) os quais comungam necessariamente de uma característica narratológica. Sua proposta é partir da análise da estrutura narrativa que sustenta a história contada no livro e verificar quais elementos foram ou não transferidos ao filme. É importante ressaltar que, por essa, a questão da fidelidade de uma obra a outra não deve ser o cerne do estudo. Para o autor, o critério fidelidade é sempre passível de crítica e nunca deve ser o elemento fundamental da análise, já que nem sempre as adaptações mais fiéis alcançam maior êxito.

Apesar de dar origem a um novo objeto artístico, de acordo com Mcfarlane (apud BELLO, 2011, p. 145), o objetivo da adaptação é oferecer uma experiência perceptual que corresponda àquela que se obteve conceitualmente, afirmando que entre a experiência conceitual da leitura literária e a experiência perceptual da recepção cinematográfica não existe identificação, mas pode existir uma correspondência, uma resposta afetiva, emotiva e significativa semelhante.

McFarlane equipara o processo de adaptação fílmica a uma tradução intersemiótica e toda a sua base teórica concentra-se na descrição de elementos narrativos da literatura que são traduzidos do texto verbal para o cinematográfico. Já as questões referentes à autoria ou ao contexto de produção ficam para segundo plano, apesar de o crítico chamar atenção para fatores intertextuais que intervêm no processo. 
Os estudos do crítico Robert Stam também se destacam por se debruçar sobre a questão da adaptação. Com base na teoria da intertextualidade de Julia Kristeva e de Bakhtin, ele afirma (STAM, 2008) que, nas adaptações de obra literária para obra fílmica, há a transformação e a comunhão de referências intertextuais e, por isso, há a criação de outra obra. Assim, o crítico que sugere um texto pode gerar diversas adaptações em razão da possibilidade de diferentes leituras. Para ele, o dialogismo intertextual pode auxiliar a vencer as discussões sobre fidelidade.

A adaptação torna-se, inexoravelmente, diferente e ao mesmo tempo original da obra a qual se baseia, devido à alteração do meio de comunicação. A passagem de um meio unicamente verbal como o romance para um meio multifacetado como o filme, que pode jogar não somente com palavras (escritas e faladas), mas ainda com música, efeitos sonoros e imagens fotográficas animadas, explica a pouca probabilidade de uma fidelidade literal, que eu sugeriria qualificar até mesmo de indesejável. (STAM, 2008, p.20)

Nessa mesma perspectiva se posiciona a crítica portuguesa Maria do Rosário Lupi Bello (2011) ao reiterar que a adaptação depende de um processo de leitura, mas ultrapassa-o, dando origem a um novo objeto artístico com existência e significados próprios. Os motivos que levam a literatura ser traduzida para a linguagem cinematográfica são vários e a autora coloca como ponto central a consideração de McFarlane, em que a adaptação se dá pela "urgência de dar corpo aos conceitos verbais através da concretude da percepção" (apud BELLO, 2011, p. 144). Nesse sentido, a adaptação cinematográfica poderia ser vista como uma desejável e natural continuação do trabalho da leitura literária.

Por fim, mencionamos o posicionamento favorável às adaptações da crítica canadense Linda Hutcheon (2006). Em seu livro A Theory of Adaptation, ela busca sistematizar e analisar questões teóricas relacionadas à adaptação, levando em consideração também aspectos práticos, como: as razões de se adaptar, por que adaptar e até mesmo fatores econômicos. Para a autora, as adaptações são positivas porque geram uma acumulação de 
leituras com as várias versões de uma mesma história através de uma espécie de sedimentação de sentidos.

Hutcheon (2006) ressalta que, em razão do caráter duplo da adaptação, a qual pode indicar um processo e um produto, é importante que o estudioso se posicione frente a essa duplicidade de instâncias que são distintas, mas intrínsecas ao mesmo tempo. De acordo com a crítica, na instância processual, a adaptação seria uma extensão de obra anterior. Já como produção, seria um processo específico de leitura e interpretação, sendo assim uma releitura do texto de origem. Ademais, chama atenção para o fato de que o campo de estudo da adaptação fílmica não deve se ater somente no binômio "literatura-cinema", mas se abrir para outras obras culturais, como o videogame, por exemplo. Dessa forma, sua proposta é a de que se superem os métodos convencionais para se alcançar um método que reflita sobre as variantes culturais, sociais, econômicas e políticas do processo de adaptação.

As mais recentes teorias da adaptação, voltadas para a superação do discurso da fidelidade, apresentam uma perspectiva mais ampla que envolve tanto os elementos internos das obras quanto os externos, verificando o diálogo que elas estabelecem entre si. Por esta nova abordagem, faz-se uma leitura interpretativa das produções culturais no movimento dos vários agentes produtores, realizadores e exibidores, englobando-se também as relações estéticas através das quais as obras artísticas representam em cada meio (literário ou fílmico) uma dada realidade sociocultural.

Assim, quando se discute a adaptação deve-se levar em conta que estamos diante de um novo tipo de texto, híbrido, que pede uma abordagem inter e transdisciplinar e que envolve toda uma complexidade; trata-se, pois, de textos em que se encontram simultaneamente signos de diferentes sistemas ou códigos. 
E, no que diz respeito à qualidade das obras literárias e cinematográficas, os críticos acreditam que essa seja devida, sobretudo, à criatividade de seus realizadores do que às características próprias do livro. É certo que sem uma boa história não há um bom filme, mas a narrativa de qualidade não é garantia. É preciso repensar a história na linguagem do cinema. Assim, o fascinante nas adaptações cinematográficas é o desafio de se propor uma releitura do livro e esse um jogo intertextual que gera desdobramentos de sentido para ambas as obras.

Portanto, ao considerar que a adaptação se define pelo diálogo intertextual o qual carrega em si categorias interdisciplinares e culturais, deve-se analisar os pontos de contato e de não-contato entre as obras, observando-se de que forma os elementos narratológicos (narrador, ponto de vista, tempo, espaço, personagens, etc.) refletem traços históricos, sociais e ideológicos cuja leitura varia constantemente no espaço e no tempo. No mais, o processo de adaptação também abarca uma atitude política que pode reforçar ou problematizar preconceitos e estereótipos, bem como apresentar outros enfoques para fatos históricos.

Desse modo, as análises desenvolvidas nessa pesquisa apresentarão uma abordagem interdisciplinar em que o filme adaptado será considerado uma nova obra de arte de pleno direito, como também abarcará sua relação com a obra de partida, por estabelecer com ela um diálogo inevitável e proveitoso, e com o seu contexto de produção, enfatizando ora as suas escolhas narrativas e estéticas das obras, ora seus posicionamentos políticos.

\subsection{O fenômeno artístico dos anos 30 na literatura e no cinema}

No início dos anos 30, eclodiu, em diversos países, uma gama de movimentos artísticos que propunham, de maneira geral, uma arte de intervenção social e política como resposta ao panorama de crise econômica (gerada pela quebra da bolsa de Nova Iorque em 1929), do pós-guerra e do surgimento de regimes totalitários no mundo ocidental. Para tanto, 
a concepção de artista defendida por tais movimentos era, em suma, a do indivíduo atuante e interventivo, voltado para a realidade que o cercava.

Nesse sentido, esses movimentos buscavam refletir e desvelar a realidade nas suas contradições mais urgentes, partindo, muitas vezes, de um postulado ideológico com o objetivo de promover a conscientização crítica dos sujeitos e, desta forma, transformar a sociedade. Assim, pode-se dizer que a arte, nesse fenômeno artístico, teria também um papel político.

Os movimentos de 30 receberam diversas designações. No Brasil, fala-se em realismo regionalista, na geração de 30, e também em regionalismo. Em Portugal e na França, temos o neorrealismo e, nos Estados Unidos, surge a chamada Lost Generation. Sem entrarmos na discussão das nomenclaturas, podemos dizer que há uma relação de parentesco entre tais movimentos no que se refere à temática e ao ideário marxista, típico da época. No entanto, cada movimento apresentava suas concepções estéticas e suas próprias motivações históricas e socioculturais.

Seria equivocado estabelecer uma relação direta entre tais movimentos e o chamado realismo socialista que se instaurou na década de 20 na antiga União Soviética, pelo qual a arte deveria, ao divulgar a ideologia do Partido Comunista, estar comprometida com a educação e a formação das massas para a construção do socialismo no país. Apesar de haver alguns pontos de convergência entre eles, como traços ideológicos e algumas das especificidades estéticas, tais movimentos são distintos.

O primeiro distanciamento que encontramos entre realismo socialista e os outros movimentos é o fato de o primeiro ter sido aprovado por decreto pelo regime socialista da antiga URSS por ocasião do $1^{\circ}$ Congresso de Escritores Soviéticos, realizado em 1934. Andrei Zhdanov, designado comissário por Stalin para cuidar da área cultural, determinou que 
a arte oficial deveria seguir a linha ideológica do Partido Comunista, tendo em primeiro plano um compromisso com a educação das massas para o socialismo, através da abordagem de temas nacionais de questões do povo russo. Toda a produção artística que não seguisse tais preceitos era censurada e seus autores duramente criticados e, até mesmo, perseguidos e mortos. Essas imposições políticas afetaram a arte soviética, pois, em meio a tanto cerceamento, havia pouco espaço para se produzir com criatividade artística.

Para Moraes (1994, p. 220),

[...] foi por não perceber a intensa complexidade do fenômeno da invenção que o realismo socialista prolatou a renúncia à dialética transformadora. Espremida entre os ideais socialistas e a disciplina partidária, a intelectualidade comunista estagnou-se no restrito elenco de alternativas da "cultura proletária". A literatura e as artes tiveram que se harmonizar, em primeiro lugar, com o viés doutrinário, interrompendo bruscamente a fluência criativa e comprometendo a autonomia estética. Com o agravante de que as interdições do imaginário, fundadas no dogmatismo, distorceram as relações entre o marxismo e a produção de conhecimento.

Já os demais movimentos da década de 30 não nasceram por decretos. Eles foram resultado de situações sociopolíticas e culturais e, como foi dito, embora houvesse uma tendência marxista e uma maior proximidade entre a arte e as massas, havia a separação entre arte, partido e Estado, algo que não se pode afirmar em relação ao realismo socialista. No entanto, cabe ressaltar que os aparelhos de informação controlados pelos partidos comunistas - que buscavam articular-se com os segmentos sociais para tentar executar o projeto revolucionário por eles engendrado - empregaram diversas estratégias políticas e ideológicas para gerar a adesão do campo artístico às teses de Andrei Zhdanov em vários lugares do mundo.

Moraes (1994, p.16) contribui para elucidar essa questão ao afirmar que [...] "a imprensa partidária se afigurou como pólo gerador de estratégias políticas e ideológicas que engendraram formas específicas de submissão da esfera artístico-literária ao chamado jdanovismo." 
No Brasil, por exemplo, grande parte dos artistas, apesar de adeptos à ideologia marxista, não submeteu sua obra às orientações e restrições formais do partido comunista, ainda que fossem muitas vezes criticados ou ameaçados por esse posicionamento. $\mathrm{Na}$ literatura brasileira, por exemplo, Graciliano Ramos recusou as fórmulas do realismo socialista e, apesar do seu engajamento, manteve um distanciamento que preservou sua independência artística.

Mais atrevido, Graciliano, mesmo pressionado pelos dirigentes, costumava encerrar de modo abrupto as discussões a respeito do dirigismo partidário. Mal ouvia falar de Zdanov e logo disparava: "um cavalo!". E a conversa acabava aí [...] (DUARTE, 1995, p. 417).

Sobre essa questão, aponta Moraes (1994, p. 206) que Graciliano Ramos “não cedeu um milímetro na sua integridade estética. Teve que caminhar no fio da navalha, tentando equilibrar-se entre a fidelidade filosófica ao partido e a firme recusa do patrulhamento".

Outros artistas, no entanto, partidarizaram mais intensamente suas obras ao se aproximarem das orientações do partido comunista. É o caso de Jorge Amado, que durante um período estreitou seus laços partidários e se deixou conduzir pelo dogmatismo. No entanto, após a morte de Stálin e as denúncias de Krushev, rompeu com o partido comunista e passou a criticar a literatura submetida a ditames partidários.

Sobre a adesão dos artistas aos dogmas do PC, Moraes (1994, p. 221) afirma que “[...] em vez de uma leitura crítica dos postulados, escritores e artistas limitaram-se a reproduzir, na imprensa partidária, o ideário do PCUS".

Podemos dizer que essa dualidade de posturas retratava uma dissonância de posições que se dava dentro dos próprios partidos comunistas. Por essa razão, vários artistas enfrentavam o dilema entre a afinidade no plano ideológico e o desconforto de submeter suas produções às orientações políticas. 
Assim, houve uma ressonância do realismo socialista nos movimentos artísticos de 30, principalmente em razão a efervescência das ideias socialistas que se dá entre os artistas e intelectuais. Entretanto, seria equivocado estabelecer um elo direto entre eles.

Grande parte das produções dos movimentos de 30 pode ser considerada engajada já que muitos artistas conferiam um caráter militante às suas produções ao se posicionar ideologicamente ao mesmo tempo em que combatiam a arte que consideravam alienante, pura ou idealista.

No tocante à literatura, de uma forma geral há nos romances de 30 uma simpatia às ideologias marxistas e à temática político-social. Além disso, tais obras literárias buscam a concretização do homem como um todo, como absoluto, e refutam o drama individual. Portanto, interessa para esta literatura o homem agindo em consonância com um coletivo em um determinado tempo e espaço e não seu universo íntimo, a não ser que este tenha relação intrínseca com o todo.

Sobre este tema, Carlos Reis (1983, p. 29) afirma que:

[...] Para isto, bastava atentar na dinâmica, essencialmente colectivista assumida pelo momento histórico em que se vivia (e que era, não o esqueçamos, o que presidia à génese do Neo-Realismo): um momento histórico em que os grandes problemas dos homens deixaram de ser individuais, para serem colectivos, em que o desemprego, a fome, as guerras são males colectivos.

Preservadas as idiossincrasias desses movimentos artísticos em cada país, a literatura dos anos 30, em linhas gerais, preocupa-se principalmente em refletir e representar a realidade e em como o discurso literário dará conta, esteticamente, dessa tarefa por meio da abordagem de um conteúdo que englobe sobretudo as questões do povo e assim, crie caminhos para a transformação da sociedade. Cabe ressaltar que, quando se fala em representação da realidade, deve-se ter em mente que não se trata de uma representação mimética e sim de uma representação que é resultado de uma interpretação racional e com bases ideológicas. 
Portanto, para tais movimentos, a literatura desse período passa a ser uma forma de conscientização do indivíduo e um modo de intervenção social. O escritor desse movimento estava ciente de que sua escrita atrelava-se a uma função de denúncia das contradições sociais geradas naquele contexto histórico. No mais, o indivíduo visto em uma coletividade passou a ser o fator determinante de possíveis mudanças.

\subsubsection{A geração perdida norte-americana}

Após o fim da Primeira Guerra Mundial, os Estados Unidos viveram um período de grandes mudanças e de rápida ascensão econômica.

Com o avanço da tecnologia, o campo se modernizou, mas, apesar da alta produtividade, o preço da safra caiu por estar vinculado aos interesses do mercado, ocasionando uma alta taxa de desemprego nas áreas rurais, o empobrecimento de muitos fazendeiros e, consequentemente, um êxodo rural.

Por outro lado, a indústria e os negócios floresceram e alavancaram a classe média. Como resultado, houve uma mudança no padrão de vida norte-americano: a renda média aumentou, mais pessoas passaram a frequentar faculdades, houve um incentivo ao uso do transporte individual (automóveis), iniciou-se a construção das chamadas highways, mudando o eixo do transporte de ferroviário para rodoviário, e consumia-se toda forma de tecnologia, tais como rádio, telefone, máquina de costura, etc.

Essas mudanças refletiram também no comportamento da mulher americana, que conquistou mais espaço na sociedade. Prova desta conquista foi a $19^{\mathrm{a}}$ Emenda à Constituição, de 1920, que garantia à mulher o direito ao voto.

Por força desta transformação, a sociedade mudou seu curso tradicional e aderiu a um movimento mais científico, rápido e tecnológico. Apesar de seus efeitos positivos, tal 
modernidade levou o homem a um estado de questionamento de sua identidade e camuflou as consequências desastrosas da Primeira Grande Guerra.

Em meio a esse contexto, um grupo de escritores norte-americanos, que vivia em Paris, passa a questionar, por meio de suas obras, essa mudança de padrão e os horrores da guerra que pareciam estar esquecidos.

A escritora estadunidense Gertrude Stein, radicada em Paris e famosa por manter um círculo de amigos formado de artistas, apelidou esse grupo de Lost Generation; traduzindo, Geração Perdida. Dele faziam parte Ernest Hemingway, F. Scott Fitzgerald, Ezra Pound, John dos Passos, T.S. Eliot, William Faulkner, entre outros.

Influenciados pela psicologia freudiana e pelas correntes marxistas, e com o advento da Grande Depressão de 30, esses escritores passaram a denunciar, por meio de suas obras, as contradições sociais dos Estados Unidos, entre outras o desemprego, a falência de agricultores, o aumento da pobreza; isto sem contar a temática sobre a guerra, que também era recorrente.

Além de retratar a realidade, eles também alteraram a estética do romance de forma que o ponto de vista e a pluralidade de vozes tornaram-se aspectos recorrentes nas narrativas.

A Geração Perdida também impulsionou o florescimento do jazz e dialoga com o realismo regionalista brasileiro e o neorrealismo português, assim como afirma Abdala Jr. (1981, p. 1):

[...] A literatura ocidental evolui pelos caminhos de um novo realismo, como resposta às tensões sociais originadas pela grande crise econômica em processo desde 1929. Destacam-se, ao logo da década de 30, as produções dos escritores norte-americanos Ernest Hemingway, John dos Passos, William Faulkner, John Steibeck, Erskine Caldwell, etc., que vieram a influenciar as literaturas americanas e europeias, invertendo o vetor da transmissão cultural da América para a Europa. 
Portanto, podemos dizer que a produção artística da Geração Perdida relaciona-se, no que diz respeito ao seu um caráter de intervenção social e suas novidades estéticas, com o movimento do realismo regionalista brasileiro e com o neorrealismo instaurado em Portugal.

\subsubsection{O neorrealismo em Portugal}

As publicações das revistas $O$ Diabo e Sol Nascente, em 1938, e do romance Gaibéus, em 1939, de Alves Redol, marcaram o início do neorrealismo em Portugal. A princípio, os artistas e intelectuais que aderiram a esse movimento entendiam que a arte deveria cumprir um papel político-ideológico e se posicionavam contra o chamado Presencismo (grupo que liderava a revista Presença), que se caracterizava por uma literatura intimista e psicológica e rejeitava a submissão da arte a qualquer princípio que não fosse artístico.

No tocante a este tema, afirma Abdala Jr. (1981, p. 3):

[...] O Neo Realismo literário português colocou-se de imediato contra o individualismo da Presença e o idealismo bergsoniano dos feudos intelectuais identificados como formalistas. Em oposição, as primeiras produções do movimento mostraram-se mais documentais, evoluindo paulatinamente no grau de elaboração estética, sem perder sua força atuante em relação à situação político-social.

Em razão dessa oposição, travou-se um embate entre José Régio, representante do

presencismo, e Álvaro Cunhal, defensor dos princípios do neorrealismo. José Régio era avesso à vinculação da literatura a qualquer causa que não fosse artística e, além disso, criticava o diálogo que se estabelece entre as literaturas brasileira e portuguesa. Já Álvaro Cunhal entendia que a literatura deveria estar comprometida política e socialmente.

Assim, pode-se dizer que o neorrealismo português foi uma resposta ao governo totalitário de Salazar (1933 a 1974), cujas bases eram de orientações nacionalista, fascista, conservadora, ruralista, antiliberal, anticomunista e colonialista. Para manter-se, o salazarismo 
se apoiava na censura, na propaganda e contava com a PIDE - Polícia Interacional e de Defesa do Estado.

Em razão das várias reformas econômico-financeiras efetuadas nos primeiros anos do salazarismo, a economia portuguesa se manteve em equilíbrio até mesmo depois da Segunda Guerra Mundial. Entretanto, continuava ela muito aquém da economia dos outros países da Europa.

Apesar de a economia portuguesa ser predominantemente rural, havia um atraso no desenvolvimento do campo, o que gerou êxodo rural.

Em meio a um contexto de insatisfação política, injustiças e atraso, os artistas e intelectuais, influenciados pelas correntes marxistas, conferiram a suas produções uma causa ideológico-política, e também social. Por isso, pode-se afirmar que esta causa comum congregou diferentes artistas e estéticas.

Da mesma forma que a produção da Geração Perdida dialogou com o florescimento do realismo regionalista brasileiro, também encontramos forte influência de autores desta geração no neorrealismo português. As obras de John dos Passos, Hemingway e Steinbeck circulavam pelo país e ganhavam adeptos, assim como seus ideais libertários.

Ademais, os romances brasileiros de 30 também contribuem na formação do neorrealismo português. Além de nomes como José Lins do Rego, Graciliano Ramos e Rachel de Queirós, temos Jorge Amado, que foi de suma importância na concretização desse movimento por meio de seu romance social. Pela primeira vez, inverteu-se o vetor de transmissão cultural uma vez que a obra amadiana passou a dialogar fortemente com as obras dos escritores da antiga metrópole.

De acordo com Ambires (2013, p. 98),

[...] o Neorrealismo português leu com paixão a obra de Amado. Alguns textos do movimento dialogaram abertamente com escritos do autor brasileiro. $\mathrm{O}$ fato, contudo, não se encerra nas circunstâncias: os temas e o 
estilo de Jorge Amado estruturam os procedimentos de escrita da primeira geração neorrealista de Portugal.

Assim, o diálogo com produções literárias neorrealistas de outros países, a proliferação de correntes marxistas, a oposição a uma literatura beletrista e, sobretudo, a dissidência ao governo de Salazar fazem com que se instaure em Portugal o neorrealismo que, em meio a uma enorme gama de estilos e autores, tem um traço comum a todos: a literatura como meio de contestação e em prol da alteração da ordem social.

\subsubsection{O realismo regionalista brasileiro}

Na década de 30, no Brasil, começa a se delinear o que alguns críticos chamam de realismo regionalista brasileiro e outros, de regionalismo. Independentemente da denominação, trata-se de um movimento artístico que, além de manter alguns dos pressupostos iniciais Modernismo, relaciona-se com os demais movimentos artísticos da década de 30. Mas, mais do que isto, dialoga diretamente com os acontecimentos históricos do período.

O romance da década de 30 também tratou do confronto entre o Brasil rural (arcaico) e o Brasil urbano (em fase de modernização), mostrando o descompasso entre as mentalidades patriarcal-latifundiária e a urbana modernizada, bem como do coronelismo e das desigualdades sociais, trazendo à cena vagabundos, prostitutas e excluídos de toda espécie. Temos como representantes desse movimento José Lins do Rego, Graciliano Ramos, Jorge Amado, Rachel de Queiroz, Érico Veríssimo, entre outros.

Grande parte da produção intelectual e artística brasileira desse movimento descartou qualquer possibilidade de transformação por via de um modelo conservador. Para ela, só seria possível pensar em qualquer mudança depois de se mergulhar profundamente nas misérias e descalabros sociais e propor uma mudança por meio de uma revolução. 


\subsubsection{Os anos 30 e o cinema neorrealista}

A efervescência artística dos anos 30 foi um amplo movimento cultural com características marcadamente políticas e elementos estéticos e temáticos inovadores que abarcou diversas expressões artísticas, inclusive o cinema.

Esse movimento cultural dos anos 30 somado às consequências do pós-guerra propiciaram o surgimento, na década de 40, do chamado cinema neorrealista italiano cujos projetos político e estético dialogaram com o cinema de vanguarda de outros países, inclusive do Brasil.

Para se entender a configuração do cinema neorrealista italiano e sua contribuição para outras culturas, é necessário compreender o momento histórico em que surgiu.

Após a Segunda Guerra Mundial, a Itália passa por um intenso processo de reconstrução da nação. Nele, os intelectuais de esquerda, principalmente os comunistas, ocupam lugar de destaque frente às manifestações culturais preocupadas em denunciar o estado crítico em que se encontrava a população italiana no segundo pós-guerra e em contribuir com a formação de uma nova consciência democrática. Inicialmente, tais manifestações perpassam a literatura, as artes plásticas e a música para, enfim, alcançarem o cinema.

$\mathrm{Na}$ contramão do movimento neorrealista estava um movimento católico que, de acordo com Mariarosaria Fabris (2006), desde 1930 exercia grande influência sob os meios de comunicação, principalmente sob a indústria cinematográfica italiana. Por manter membros eclesiásticos nas comissões de censura e controlar a distribuição de filmes e os cinemas dos bairros periféricos, esse movimento preteria as produções neorrealistas em favor das produções hollywoodianas voltadas para a cultura de massa. Assim, somente os filmes que o Centro Católico Cinematográfico considerava apropriados eram exibidos em salas de cinema. 
Em 1948, a Democracia Cristã vence as eleições e inicia-se um período em que há um tolhimento à democracia. Durante esse período, o boicote ao cinema neorrealista se intensifica ao mesmo tempo em que se aumenta a repressão e a cesura. Além disso, abriu-se mais espaço para as produções norte-americanas. Diante deste panorama, em que havia pouco ou quase nenhum espaço para as produções nacionais, e não havia incentivo governamental para a industrial cinematográfica italiana, houve mobilização em favor do cinema nacional engajado que contou com o apoio da população.

Sobre este assunto, Fabris (2006, p. 198) afirma:

[...] As forças conservadoras, uma vez no poder, não quiseram mais ser questionadas e, para afastar das telas aqueles filmes em que o povo era o protagonista da história, valeram-se da ação repressora da censura, favoreceram a importação de filmes americanos, não fizeram respeitar a lei de programação obrigatória para filmes nacionais, como já vimos; além do mais, não concederam verbas às produções italianas e entregaram o circuito nacional nas mãos de estrangeiros. Em todo caso, a derrota histórica do povo já vinha sendo pressentida pelos principais diretores neorrealistas: tanto Rossellini como Visconti de Sica encerravam suas obras mais fecundas sobre a falta de perspectiva de um futuro melhor para os personagens populares ou sobre sua renúncia à etapa da mudança social.

E neste contexto que se inicia e se dilui o cinema neorrealista italiano, cinema este que, de acordo com André Bazin (1972), se origina de uma síntese entre o desenvolvimento técnico e estético alcançados durante o fascismo e as condições sócio-políticas e econômicas da Itália.

Apesar de o neorrealismo abranger diferentes projetos estéticos, de diversos diretores, é possível perceber alguns temas e orientações estéticas comuns aos filmes pertencentes a este movimento.

Quanto à temática, é importante ressaltar que, como o neorrealismo tinha em vista aspirações revolucionárias, pois buscava a transformação das estruturas sociais e políticas, seus filmes apresentavam uma abordagem de temas sociais como as grandes guerras e suas consequências, a resistência antifascista, a questão agrária, a miséria, o desemprego, a condição da mulher italiana, a questão religiosa, entre outros. 
Já quanto à estética e à técnica, o neorrealismo procurava retratar a realidade em sua plenitude, transcrevendo experiências comuns aos sujeitos por meio de uma de estética que privilegiasse o documental. Por esta razão, esses filmes se utilizam de cenários reais e ambientes naturais, de planos médios e de conjunto de modo que a câmera registre de forma pretensamente objetiva a realidade, da utilização de imagem acinzentada, da atuação de atores não profissionais, mas sem dispensar o elenco de atores famosos, do uso de linguagem simples, privilegiando o dialeto, e de maior liberdade de atuação, o que conferia menos rigidez aos roteiros.

Assim, afirma Bazin (1992, p. 20) que "os filmes italianos têm uma excepcional qualidade de documentário a qual não poderia ser removida do roteiro sem eliminar todo o contexto social".

Portanto, as produções fílmicas neorrealistas italianas se valem de um domínio técnico e de uma estética do documental que vão ao encontro de um projeto político que objetiva, por meio da abordagem de problemas sociais, levar seus espectadores a refletir criticamente sobre a realidade e promover uma verdadeira transformação de suas estruturas sociais e políticas.

\subsubsection{A recepção do neorrealismo italiano pelo cinema brasileiro}

Para analisarmos a recepção do cinema neorrealista italiano pelo cinema brasileiro, é necessário voltar à década de 30 e traçar um panorama do cinema nacional daquela época.

O Estado getulista exercia controle sob a produção cinematográfica. Assim, o cinema era utilizado como instrumento de condução das massas e como forma de propaganda política. A maior parte das produções desse período estava alinhada a uma política 
nacionalista que passava uma imagem de país unificado e harmonioso, exaltando o nacional de forma estereotipada.

O cinema brasileiro nos governos de Vargas era feito, em sua maioria, para entreter e não para propiciar uma reflexão crítica da realidade. Além das poucas produções nacionais e de seu caráter nacionalista e "didático" - ou seja, destinadas a popularizar e difundir a ideologia do Estado Novo -, tínhamos grande parte de nossas salas de cinema exibindo filmes hollywoodianos que também procuravam, por meio de uma fórmula clichê, somente divertir seu público.

A utilização do cinema pelo Estado, que se valia de mecanismos para impedir que a crueza da realidade brasileira chegasse às telas, e a invasão maciça de filmes norteamericanos fizeram com que a produção do cinema nacional se voltasse predominantemente à produção de filmes estereotipados, apesar de nesse período se ter obras que se sobressaíram por não seguir esses modelos e se consolidaram como verdadeiras obras de arte.

Para combater este cenário, alguns veículos de informação - o jornal "O Estado de São Paulo" e a revista "Anhembi”, por exemplo - publicaram matérias questionando o papel e o espaço dados aos filmes nacionais.

Poucos meses após a veiculação destas matérias, nasceu em São Paulo, pelos mesmos fundadores do TBC e do MAM, o Complexo Cinematográfico Vera Cruz com o propósito de revitalizar o cinema nacional com excelência e produzir películas com qualidade. Para tanto, contrataram-se técnicos estrangeiros.

Afirma Fabris (1994, p. 42) que:

[...] Para levar adiante essa aventura cinematográfica, foram chamados da Europa o cineasta brasileiro Alberto Cavalcanti (que, tendo participado da Avant-garde francesa e do documentarismo inglês, havia conquistado renome internacional) e técnicos estrangeiros - Chick Fowle, Ray Sturges, Michael Stoll, Rex Endsleigh, Erik Rassmussen, Oswald Haffenrichter, Jacques Deheizelin, Bob Huke, John Waterhouse, entre outros - com os quais se esperava formar toda uma geração de técnicos brasileiros. 
Se por um lado a Vera Cruz contava com mão de obra especializada, por outro trabalhava com um grande número de amadores, o que gerou embates durante a produção dos filmes.

Além disso, a Vera Cruz confiou a distribuição dos filmes às companhias norteamericanas, mas estas viam no nosso cinema um concorrente e, por isso, colocaram barreiras na circulação e distribuição dos filmes, criando entraves no desenvolvimento da indústria cinematográfica brasileira.

No mais, um grupo de cineastas brasileiros formado por Nelson Pereira dos Santos, Rodolfo Nanni, Flávio Tambellini e Alez Viany havia desenvolvido um projeto para levar às telas filmes que retratassem a realidade brasileira por meio da exploração dos costumes e do dia-a-dia do brasileiro. Buscavam, assim, recuperar o cinema e a identidade nacional. Esse projeto, levado a debate em congressos e seminários sobre cinema, deu início a uma mobilização em defesa do cinema nacional.

Enfrentando diversos percalços e a crítica ferrenha de revistas especializadas, a Vera Cruz encerrou suas atividades.

As barreiras impostas pelos estúdios para produzir filmes engajados e a falta de recursos fizeram com que os realizadores desse tipo de filme buscassem outras soluções para a revitalização do cinema brasileiro.

Neste sentido, eles vão se valer das propostas do neorrealismo italiano para alcançar seus objetivos. "Não era nos soviéticos, mas nos neo-realistas italianos que os jovens aspirantes a cineastas paulistas iam buscar sua principal fonte de inspirações para projetos futuros." (SALEM, 1996, p. 88).

Nesta perspectiva, os projetos estético e político do movimento neorrealista estavam em consonância com o projeto destes realizadores. O caráter documental, o baixo custo das produções, a temática social, o projeto de transformação social, a recusa da utilização de 
efeitos especiais e as outras orientações do neorrealismo se adequam à realidade brasileira e aos ideais destes realizadores.

Como os estúdios recusavam filmes que abordassem a temática social, passou-se a produzir filmes de forma independente e com uma proposta estética e política nova.

Assim, os novos cineastas, buscando renovação do cinema brasileiro, começam a dialogar com o cinema europeu do pós-guerra e, nessa primeira fase, principalmente com o neorrealismo italiano. Pretendia-se construir uma imagem nacional, através de um posicionamento crítico, abalando as estruturas conservadoras pela subversão da narrativa, passando a rechaçar os filmes de chanchada e o formato disseminado por Hollywood.

O precursor do Cinema Novo, o filme "Rio, 40 graus" criou polêmica, foi censurado, mas abriu espaço para realizações de outros cineastas e, mais do que isto, inspirou um movimento que buscava a realização de filmes mais críticos e engajados que revelassem a realidade brasileira por meio de um questionamento crítico da realidade.

\subsection{As adaptações da obra literária Capitães da Areia}

O fato de a obra amadiana ter sido adaptada para vários veículos, como televisão, cinema, teatro e até mesmo rádio, impulsionou sua popularização e sua internacionalização, sem mencionar na sua contribuição para a formação de uma identidade nacional que ainda percorre o mundo.

No tocante ao romance Capitães da Areia, é importante ressaltar que a obra foi adaptada para teatro, cinema, televisão, espetáculo de dança e quadrinhos.

Quanto às adaptações para o teatro, subiu aos palcos de Salvador, em 1958, o espetáculo dirigido e adaptado pelo padre Valter Souza. Houve também as adaptações de Carlos Wilson, encenada por diversos grupos teatrais no Brasil e no exterior, e de Roberto Bomtempo, pela Companhia Baiana de Patifaria, em 2002. Em 2012, a obra volta a ser 
encenada pelo grupo Trapiche, de São Paulo, pelo grupo Arte em Cena, do Rio de Janeiro, e pelo grupo formado pelo elenco do filme homônimo de Cecília Amado, na Bahia.

A obra também foi adaptada para a dança. Friederich Gerlach, em 1971, na Alemanha, foi um dos pioneiros ao dirigir um espetáculo de dança sobre a obra Capitães da Areia. Anos depois, mais precisamente em 1987, Nanci Gomes Alonso dirige outro espetáculo de dança adaptado da obra, na Argentina. Em 1988, o Grupo Êxtase, de Minas Gerais, estreou um espetáculo baseado no romance e, neste mesmo ano, Raymond Foucalt e Plinio Mosca dirigiram outro espetáculo na França.

Em relação à televisão, Capitães da Areia foi adaptado para uma série televisiva de 10 capítulos da Rede Bandeirantes, em 1989, sob a direção de Walter Lima Jr. e roteiro de José Loureiro e Antônio Carlos Fontoura. O elenco era formado por Leandro de Souza, Bruno Sobral, André Gonçalves, Pablo Sobral, Rodrigo Pereira da Silva, Tâmara Taxman, Jacyra Silva, Geraldo Del Rey, Marcus Vinicius, Miriam Pires, Isolda Cresta, Jackson de Souza, entre outros.

O romance também foi adaptado para quadrinhos pelo publicitário Ruy Trindade e, um trecho do romance, pelo cartunista Rodrigo Rosa, contratado pela Editora Globo para realizar esse trabalho.

Já em 2011, a empresa Porreta Games, apoiada pela Secretaria da Cultura da Bahia e por meio do Programa Vivo Lab, da empresa Vivo, adaptou a obra Capitães da Areia para jogos eletrônicos online. O projeto consistiu na criação de sete jogos inspirados no livro, que se dividem em um jogo de realidade alternativa, um jogo social e cinco jogos casuais.

Em 1971, o romance tem a sua primeira adaptação para o cinema realizada pelo diretor americano Hall Bartlett. Inicialmente, o título da narrativa fílmica era The Sandpit Generals, mas foi apresentado ao público por outros dois títulos The Defiant e The Wild Pack. 
Essa produção não fez sucesso nos Estados Unidos, talvez porque o centro do capitalismo não abraçasse uma obra com tendências socialistas. Entretanto, foi de grande repercussão na Rússia, onde se tornou referência, concorrendo ao Festival Internacional de Cinema de Moscou em 1971.

A produção americana foi inteiramente filmada em Salvador e arredores em 1969 e estrelada por atores americanos e brasileiros.

Em 1973, ano em que estreou nos cinemas soviéticos, o filme foi assistido por cerca de 43 milhões de pessoas, segundo a pesquisadora Elena Beliakova, sendo considerado um dos filmes americanos de maior sucesso exibido na ex-URSS nos anos 70.

Em 2011, Capitães da Areia volta para as telas do cinema pela direção de Cecília Amado, neta de Jorge Amado. 
Capítulo 2 - As marcas da matéria histórica nos projetos político e estético dos Amados: a autoria em foco

\subsection{Contexto histórico de Jorge Amado no momento de produção do romance}

Como vimos, na década de 30, no Brasil, começa a se delinear um movimento artístico que dialoga diretamente com os acontecimentos históricos do período.

Segundo Antonio Candido (1989, p.158), o que caracteriza a literatura brasileira, que se consolida como sistema na década de 30, é:

[...] a superação do otimismo patriótico e a adoção de um tipo de pessimismo diferente do que ocorria na ficção naturalista. Enquanto este focalizava o homem pobre como elemento refratário ao progresso, eles desvendam a situação na sua complexidade, voltando-se contra as classes dominantes e vendo na degradação do homem uma consequência da espoliação econômica, não do seu destino individual.

O primeiro acontecimento que conversa com esse movimento artístico da década de 30 é a Revolução Russa de 1917, pela qual Lênin assumiu o governo da Rússia e implantou o socialismo, prometendo uma sociedade livre e igualitária. Formou-se, então, a União das Repúblicas Socialistas Soviéticas, em que vigorava um partido único, o Partido Comunista, e houve a nacionalização dos bancos e indústrias. Apesar do grande crescimento econômico e da URSS ter se tornado uma potência econômica e militar, não se podia ter um estado democrático, pois havia repressão a qualquer manifestação contra o sistema.

Um dos desdobramentos da revolução soviética foi a formação do chamado compagnons de route, que era a designação dada ao grupo de artistas e intelectuais simpatizantes do socialismo e que articulava sua produção aos ideais deste sistema, procurando conscientizar as massas e mostrar o caminho de superação das desigualdades. 
Assim, "a prosa e a poesia reencontram a motivações épicas, encarnadas agora no combatente operário ou camponês, no agitador e o dirigente partidário.” (DUARTE, 1996, p. 21).

Como reflexo desta efervescência, tivemos, no Brasil, um período de greves e manifestações anarquistas durante os anos de 1917 a 1920. Alguns artistas, como Lima Barreto, expressavam seu apoio a estes movimentos e defendiam um processo revolucionário que colocasse o Brasil nos mesmos trilhos que a URSS.

Já em 1922, três acontecimentos iriam influenciar diretamente no contorno da produção artística brasileira dos anos 30. Foram eles: a Semana de Arte Moderna, a fundação do Partido Comunista e o chamado Levante de Copacabana contra a República Velha, de base oligárquica. Estes movimentos semearam parte dos pressupostos que delinearam a produção neorrealista do Brasil nos anos 30.

Sobre este assunto, afirma Duarte (1996, p. 23):

[...] Modernismo, tenentismo e comunismo superam a condição de meros acontecimentos circunscritos ao ano de 1922 e constituem-se balizas muito claras para a literatura que irá surgir a partir de 1930. O chamado romance de 30, a par de seus vínculos com a tradição regionalista do século XIX, muito deve à revolução estética iniciada em 22. Basta lembrar a preocupação com a identidade nacional (e com as diferenças regionais), com a renovação da linguagem literária e a pesquisa de formas populares de expressão. 30 vai herdar, como é sabido, boa parte deste sentido de modernidade bafejado na literatura brasileira a partir de 22. Mas vai sofrer, da mesma forma, o impacto da derrubada da República Velha e da nova configuração política instalada com a vitória dos liberais. Além, é claro, da radicalização ideológica operada em toda literatura mundial pelo confronto do comunismo com o fascismo.

Assim, a intensificação do movimento operário, as vanguardas artísticas, a deflagração do movimento tenentista que culminou com a formação da Coluna Prestes em 1925 e, por fim, a Revolução de 30 seriam reações a um panorama de crise econômica, política, cultural e ideológica que colocava em cheque a estrutura da República Velha e iria refletir na produção de uma nova arte preocupada com as desigualdades sociais e a superação de nosso atraso. 
Estes movimentos que desembocaram na Revolução de 30 se deparam com um resultado frustrante, pois o regime Vargas não atingiu a expectativa de transformação já que grande parte dos aspectos arcaicos da sociedade brasileira se manteve.

Este panorama é agravado com a crise econômica de 1929, o que faz com que o Partido Comunista ganhe espaço e adeptos. Textos de Marx, Lênin, Trotski e romances russos são traduzidos, publicados e lidos por uma massa cada vez maior. Mas é importante ressaltar que esta tendência não é restrita ao Brasil: a vertente político-ideológica domina a atividade cultural em todo mundo.

Nessa perspectiva, ensina-nos Duarte (1996, p. 23):

[...] De 1930 a 1933, a presença da classe trabalhadora na literatura brasileira se afirma de modo palpável, numa relação homóloga à intensificação, no plano social, das lutas pela conquista dos direitos trabalhistas. Em 1931, publicam-se os Poemas Proletários, de Paulo Torres e o romance $O$ Gororoba de Lauro Palhano, que se juntam à novela Bruhaha de Pedro Mota Lima na constituição de uma literatura social de nuances esquerdistas. $O s$ Corumbas, de Amando Fontes, publicado em 1933, denuncia a degradação de uma família interiorana a partir de sua inserção no contexto urbano e fabril do Nordeste.

Portanto, grande parte da produção intelectual e artística brasileira desse movimento descartou qualquer possibilidade de transformação por via de um modelo conservador. Para ela, só seria possível pensar em qualquer mudança depois de se mergulhar profundamente nas misérias e descalabros sociais e propor, por meio da revolução socialista, a superação desse panorama. No entanto, outra parte da produção intelectual não se submetia às regras ditadas pelo Partido Comunista. Houve uma cisão entre os próprios intelectuais que defendiam as causas socialistas.

Sobre tal cisão, conta-nos Jorge Amado (2006, p.24-25):

O Primeiro Congresso de Escritores Brasileiros, convocado pela recémformada Associação Brasileira de Escritores (ABDE), reunido no Teatro Municipal de São Paulo ultrapassou de muito os limites de festivo convescote literário para ganhar foros de acontecimento histórico, marco na luta contra a ditadura do Estado Novo ainda no poder mas já abalada nos seus fundamentos pelas derrotas militares de Hitler. Fui despachado da Bahia para São Paulo pelo pecê com a tarefa de colaborar na 
organização do conclave, tentar impor-lhe a linha política dos comunistas. A chamada unha justa daqueles que estavam de acordo com a direção partidária saída da Conferência da Mantiqueira*, pois muitos dela discordavam e só vieram acolher-se ao redil quando receberam ordens expressas de Prestes, ainda preso mas já mandando e desmandando

É com essas convicções que Jorge Amado elabora parte de sua produção literária e,

Capitães da Areia é um dos livros em que a temática política condensa os projetos do autor.

Assim, em 1937, Jorge Amado lança o livro que seria um dos seus maiores sucessos, Capitães da Areia. Sua primeira edição, lançada logo após a implantação do Estado Novo, foi apreendida, incinerada e proibida por ser considerada simpatizante da ideologia comunista, conforme ata de incineração abaixo transcrita.

\section{ATA DE INCINERAÇÃO}

Aos dezenove dias do mês de novembro de 1937, em frente à Escola de Aprendizes Marinheiros, nesta cidade do Salvador e em presença dos senhores membros da comissão de buscas e apreensões de livros, nomeada por ofício número seis, da então Comissão Executora do Estado de Guerra, composta dos senhores capitão do Exército Luís Liguori Teixeira, segundotenente intendente naval Hélcio Auler e Carlos Leal de Sá Pereira, da Polícia do Estado, foram incinerados, por determinação verbal do sr. coronel Antônio Fernandes Dantas, comandante da Sexta Região Militar, os livros apreendidos e julgados como simpatizantes do credo comunista, a saber: 808 exemplares de Capitães da areia, 223 exemplares de Mar morto, 89 exemplares de Cacau, 93 exemplares de Suor, 267 exemplares de Jubiabá, 214 exemplares de País do carnaval, 15 exemplares de Doidinho, 26 exemplares de Pureza, 13 exemplares de Bangüê, 4 exemplares de Moleque Ricardo, 14 exemplares de Menino de Engenho, 23 exemplares de Educação para a democracia, 6 exemplares de Ídolos tombados, 2 exemplares de Idéias, homens e fatos, 25 exemplares de Dr. Geraldo, 4 exemplares de Nacional socialismo germano, 1 exemplar de Miséria através da polícia.

Tendo a referida ordem verbal sido transmitida a esta Comissão pelo sr. Capitão de Corveta Garcia D'Ávila Pires de Carvalho e Albuquerque e a incineração sido assistida pelo referido oficial, assim se declara para os devidos fins.

Os livros incinerados foram apreendidos nas livrarias Editora Baiana, Catilina e Souza e se achavam em perfeito estado.

Por nada mais haver, lavra-se o presente termo, que vai por todos os membros da Comissão assinado, e, por mim segundo tenente intendente naval Hélcio Auler, que, servindo de escrivão, datilografei. (assinados)

Luís Liguori Teixeira, Cap. Presidente

Hélcio Auler, Segundo-Tenente Int. N.

Carlos Leal de Souza Pereira ${ }^{6}$

6 Transcrito de $O$ Estado da Bahia, de 17 de dezembro de 1937. Disponível em: http://www.unicamp.br/iel/memoria/ projetos/ensaios/ ensaio19.html. Acesso em 10 de janeiro de 2015. 
Somente em 1944 a obra foi reeditada e passou a circular o mundo. O romance conta as peripécias de um grupo de meninos de rua que encontra inúmeras formas de sobrevivência sob o comando do personagem Pedro Bala. Temas como exclusão social, engajamento político, greves, opressão dos sistemas coercitivos do governo, tensão, diferenças de classes sociais, delitos, violência, sincretismo religioso, entre outros, são abordados pela obra de cunho socialista, sob uma perspectiva humanizada e lírica que não deixa de denunciar os efeitos da marginalidade nos jovens e sua intrínseca relação com um sistema social perverso.

Sob esta perspectiva, temos, em Capitães da Areia, um autor comprometido ideológica e politicamente e que busca uma aliança com o leitor provindo das classes populares. Segundo José Paulo Paes (2000), a obra amadiana é uma narrativa "o quanto mais possível ao aderente popular". Isto porque o projeto político de Amado via na revolução o meio de combate das injustiças e exclusão social. Assim, o autor acreditava que a literatura deveria conscientizar criticamente seus leitores e levá-los à revolução que os colocaria no centro da cena política e histórica do país.

Ao abordar a problemática dos menores de rua, Capitães da Areia também revela a seu leitor outros problemas que já estavam enraizados na realidade brasileira antes mesmo da implantação do Estado Novo e que se perpetuaram com o caminhar da História. Portanto, a narrativa denuncia a acirrada desigualdade social brasileira, a opressão e a violência praticadas pelos sistemas coercitivos e seus agentes, o precário sistema de saúde, o poder e a influência do catolicismo, a imposição de valores das classes dominantes, etc.

Esta ficção voltada para a representação, denúncia e conscientização social se veste de uma forma romanesca e uma das explicações para esta escolha do autor seria a solução encontrada por ele para contemplar e amalgamar seus projetos ficcional, político e ideológico. O que não quer dizer que tal escolha não tenha gerado contradições no romance, que serão abordadas posteriormente. 


\subsection{A internacionalização de Jorge Amado}

Quando nos referimos à literatura amadiana, não podemos esquecer que se trata de uma literatura que tem larga aceitação mundial. Seus livros foram traduzidos para centenas de idiomas e serviram de referência para a literatura de característica social de diversos países.

Um destes países foi Portugal. A literatura de Jorge Amado estabeleceu um franco diálogo com o movimento neorrealista português, conforme afirma Maria da Luz Rosinha (2012, p. 5):

[...] vem reforçar a ideia de que o escritor baiano não foi só uma das vozes internacionais mais ativas na afirmação de uma literatura de inspiração social e política, como assumiu uma influência à escala mundial que teve, desde cedo, repercussões na literatura portuguesa de meados do século passado. Aliás, na correspondência trocada entre Jorge Amado e Alves Redol, dá-se conta do relacionamento estabelecido ao longo dos anos com vários neorrealistas portugueses, percebendo-se desde logo a teia de laços e influências que se gerou entre esse grupo de intelectuais que, sabendo "ler" e interpretar os sinais de sua época, tomaram como ofício o de uma escrita de oposição política e de despertar consciências.

Ainda sobre a recepção da obra amadiana pelo movimento neorrealista português, lembramos que Jorge Amado trocou correspondência durante anos com vários autores portugueses, entre eles Orlando Costa, Alves Redol e Mário Dionísio.

Além disso, nos arquivos do escritor Joaquim Namorado foram encontrados os originais de um texto refletindo sobre a obra de Jorge Amado e o diálogo que a mesma estabeleceu com o neorrealismo português.

No mais, nos espólios de Aleixo Ribeiro e Alves Redol, escritores portugueses, constavam as primeiras edições de alguns romances amadianos. Em algumas delas, é possível ver dedicatórias assinadas por Jorge Amado.

E não podemos esquecer que foram publicados três textos - do autor Mário Dionísio - sobre Jorge Amado na revista $O$ Diabo, famosa por seu conteúdo neorrealista. 
Ainda sobre este assunto, declara Abdala Jr. (1981, p. 2):

[...] Nessa situação histórico-cultural formaram-se, com análogas preocupações sociais, as literaturas brasileira e portuguesa da época: primeiro, a brasileira e, depois, próximo da Segunda Guerra Mundial, portuguesa. Entre os brasileiros figuram Graciliano Ramos, José Lins do Rego, Jorge Amado, Érico Veríssimo e Amado Fontes que, como os ficcionistas norte-americanos, influenciaram profundamente a prosa de ficção portuguesa da década de 40, como as produções de Alves Redol, Carlos de Oliveira, Manuel da Fonseca, José Cardos Pires, Fernando Namora e outros.

Portanto, podemos verificar que a leitura de obras de Amado, assim como de outros autores da geração de 30, contribuiu para o surgimento de um movimento que apresentava uma nova proposta estética em Portugal e foi chamado de Neorrealismo.

Quanto a países africanos de Língua Portuguesa, não seria exagero afirmar que as relações entre o Brasil e a África se dão em diversos campos, estabelecendo uma conexão vigorosa e de múltiplas trocas.

No tocante à literatura, percebemos que, por meio desta, a cultura brasileira contribuiu na formação do pensamento nacionalista, principalmente dos países africanos de Língua Portuguesa, conforme ensina a professora Rita Chaves (2005, p. 276):

[...] Trata-se da projeção do Brasil, em imagens diferenciadas, na formação do pensamento nacionalista de países como Angola, Cabo Verde e Moçambique. Principalmente através da literatura, mas não só, a cultura brasileira desempenhou um forte papel no processo de conscientização de muitos setores da intelectualidade africana, fornecendo parâmetros que se contrapunham ao modelo lusitano.

Nesta perspectiva, o Brasil funcionava como uma espécie de referência para esses países, já que havia conquistado a independência da Coroa Portuguesa em 1822. Muitos africanos viam no Brasil um modelo de emancipação, já que comungavam da mesma experiência de país colonizado. 
Ensinam-nos Martin e Moraes (2011, p. 71-72):

[...] No terreno da literatura, as marcas da presença brasileira na formação das literaturas produzidas nos países africanos colonizados por Portugal são muito significativas e apontam para a criação de um patrimônio cultural forjado a partir do diálogo estabelecido entre brasileiros e africanos. De fato, especialmente em meados do século XX, a nossa produção literária foi uma espécie de modelo inspirador para a produção dos escritores africanos das então colônias portuguesas, funcionando como referência cultural alternativa às imposições metropolitanas.

Por esta razão, muitos autores bebiam da fonte da literatura brasileira e há diversas produções literárias que dialogam com nosso escritor baiano. É o caso de Poema para Jorge Amado, de Noêmia de Sousa (apud ABDALA JR., 2007, p 220), transcrito abaixo:

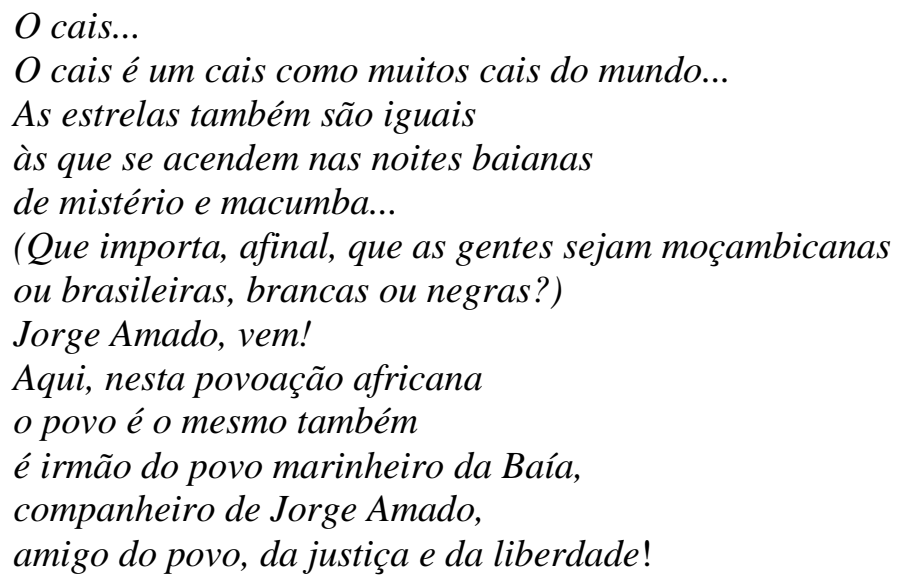

Vemos, portanto, que a recepção da literatura amadiana foi grande nos países africanos de Língua Portuguesa. Ela funcionou como fonte imagética de uma identidade nacional que conferiu a essas nações um modelo de mobilização para a realização de um projeto de independência.

Além de sua ampla recepção em países de África, Amado também teve grande aceitação nos países da antiga União Soviética e outros países europeus, como França, Polônia e Alemanha Oriental.

No final dos anos 30, os livros de Jorge Amado chegam à França e passam a circular, grande parte por causa da amizade do autor baiano com intelectuais estrangeiros de esquerda 
e, também, em razão de seu ativismo político e da divulgação de sua obra em jornais e revistas partidários.

Afirma Duarte (2002) que

Ao chegar, Jorge Amado não era de todo desconhecido do público francês. Antes da Segunda Guerra, Jubiabá já surgira na França sob a tradução Bahia de tous les saints (1938), tendo, inclusive, leitores ilustres. André Gide anota em seu Journal (1981) críticas severas ao texto escrito por Amado aos 23 anos e afirma: "não posso me interessar por essa narrativa linear, isto é, sem espessura, unicamente discursiva, embora admita a presença de certas qualidades, aliás, vulgares." Já Albert Camus, mais atento ao fato de que esta "vulgaridade" provinha do projeto amadiano de "escrever para as massas", vê a "utilização comovente de temas folhetinescos, num abandono à vida no que ela tem de excessivo e desmedido". E acrescenta: "Aqui não se discute sobre o amor. Basta amar e com toda força. Aqui não se encontra a palavra fraternidade, mas mãos de negros e de brancos (não muitas) que se apertam. E o livro inteiro é escrito como uma sequência de gritos ou de melopeias, de avanços e de retornos. Nada é indiferente, tudo é comovente." 7

Como vemos, a crítica francesa também se dividia em relação à obra amadiana. No entanto, apesar dessa contradição, os romances de Amado tiveram uma grande receptividade neste país, pois, além de estarem em sintonia com o contexto histórico da época, colocavam as camadas mais baixas da sociedade no centro da narrativa e adotavam um estilo folhetinesco que agradava às massas.

No tocante à receptividade da obra amadiana na Alemanha, em 1950 surgem as primeiras traduções para a língua alemã dos romances Jubiabá e Mar Morto. É importante destacar que, em razão divisão da Alemanha, a obra do nosso escritor baiano tem uma recepção diferente na Alemanha Ocidental e na Alemanha Oriental. No lado socialista, os romances de Jorge Amado eram vistos como obras políticas. Por esta razão, ele se torna um dos escritores estrangeiros mais influentes e com quase todas as obras traduzidas para a língua alemã.

\footnotetext{
${ }^{7}$ Disponível em: <www.letras.ufmg.br/poslit>. Acesso em: 3 mar. 2014.
} 
Já do lado capitalista, a obra amadiana começa a ter uma maior circulação depois da publicação de Gabriela, Cravo e Canela, no final da década de 50. Na Alemanha Ocidental, Jorge Amado não era visto como um escritor político e, sim, como um autor de best-sellers e um contador de histórias que pendiam entre exotismo e erotismo.

Novamente, temos a obra amadiana ocupando dois polos. Do lado oriental alemão, Amado era o escritor comunista engajado na denúncia das injustiças sociais. E, do lado ocidental, era o escritor que explorava o lado exótico e sensual da cultura brasileira.

Em relação à Polônia, como havia carência de obras literárias polonesas, esta inicia a importação de obras da União Soviética com o fim de promover e consolidar os valores da ideologia comunista. Foi por meio dessas obras que se chegou aos romances amadianos, publicados ali na década de 40 .

De acordo com o estudo elaborado por Jezdzikowski (2010, p. 154-155),

[...] As biografias do romancista brasileiro e as notícias a seu respeito veiculadas na imprensa polonesa, reforçam o ideal do escritor comunista comprometido com as diretrizes do PC. Os metatextos veiculados nos periódicos especializados enquadram a obra de Jorge Amado dentro das exigências do realismo socialista. As convicções políticas do próprio escritor, defendidas nos seus textos e comprovadas pela realização das tarefas outorgadas pelo partido, identificam Jorge Amado com o megasistema sociocultural soviético. As viagens do autor pela União Soviética e pelas Democracias Populares, assim como uma rede de relações de amizade com os dirigentes da vida política e cultural desses países, colaboram para seu sucesso como escritor nos sistemas literários de todo o bloco comunista na época do stalinismo. Com o boom da literatura ibero-americana no sistema mundial de literatura, Jorge Amado recomeça a ser traduzido e editado na Polônia. Embora se abra para o exotismo e o sensualismo dos escritos do autor baiano, a imprensa polonesa, nessa época, continua a associar Jorge Amado à militância comunista.

Assim, a grande receptividade de Jorge Amado na Polônia é, mais que um reflexo do contexto histórico e político daquele país, um desdobramento da aceitação em grande escala que tem o autor nos países da antiga e extinta União Soviética. 
A relação de Amado com a União Soviética se intensifica em 1949, ano em que o autor é obrigado a deixar seu exílio na França por sua atuação política. Nesse momento, o escritor baiano e sua família se exilam na Tchecoslováquia, onde viveriam por três anos até voltar ao Brasil.

Durante este período, Jorge Amado viaja pelos países do bloco comunista e entra em contato com vários artistas, intelectuais e políticos, além de participar de eventos literários e reuniões do Partido Comunista.

Por sua atuação, pela sua rede de contatos e, principalmente, por sua obra estar em consonância com o stalinismo, no final da década de 40 todos os seus romances publicados até então são traduzidos para as línguas dos países integrantes da URSS.

Em 1951, Jorge Amado recebe o prêmio Stalin Internacional da Paz, que consagra e canoniza sua obra. Por esta razão, ela passa a ser irrestritamente recebida pelo bloco soviético.

Um dos livros que teve grande circulação entre os soviéticos, principalmente entre os que viviam no campo, foi Seara Vermelha. Uma possível explicação é que havia uma identificação entre as experiências vividas pelos soviéticos com as narradas pelo livro, mas, mais do que isto, a obra exprimia uma mensagem de esperança, tão desejosa pelos russos.

Como podemos perceber, a literatura amadiana sofre um processo de internacionalização que se apoia tanto nas relações que estabelece com os ditames comunistas quanto no estilo adotado pelo autor que envolve os leitores. Ao se projetar internacionalmente, independentemente dos motivos, os romances de Amado carregam com eles uma imagem da identidade nacional. O Brasil está expresso nas páginas de cada um dos livros do autor baiano e é esta imagem que ganhou o mundo. Por isto, é tão importante que aprofundemos os estudos de sua obra. 


\subsection{Contexto histórico de Cecília Amado no momento de produção do filme}

Em outro contexto histórico, a obra Capitães da Areia é levada às telas do cinema pela neta do autor, em comemoração ao centenário de nascimento do Jorge Amado.

Para tratar de tal produção cinematográfica em um contexto contemporâneo, é necessário entender, em linhas gerais, o caminho percorrido pelo cinema brasileiro desde o chamado Cinema Novo até o início do Cinema de Retomada.

Nos anos 50, inaugura-se o chamado Cinema Novo Brasileiro cujo diálogo com o cinema neorrealista italiano e com os desdobramentos da Guerra Fria impulsiona a adoção de uma nova estética e de novos temas que buscam denunciar os problemas da sociedade brasileira.

Entretanto, com o golpe militar de 64, essa produção é cerceada. Em 1969, cria-se a Embrafilme, empresa estatal responsável pelo fomento do cinema brasileiro mas que, por meio dos órgãos de censura instituídos pelo AI-5, passa a controlar, por mais de duas décadas, toda a produção cinematográfica brasileira, assim como seu conteúdo.

No começo dos anos 90, em razão do término do regime ditatorial e a implantação do programa de desestatização, a Embrafilme encerra suas atividades e inicia-se um período de ínfima produção cinematográfica.

Após a implantação do Plano Real e a adoção de um sistema neoliberal de governo, institui-se uma política de incentivo às novas produções culturais, visando à formação de uma indústria cinematográfica nacional. E, para alavancar tal indústria, promulgam-se normas de fomento como, por exemplo, a Lei Rouanet.

Começa, então, a retomada das produções cinematográficas que promoveu uma mudança na formatação dos filmes já que contava com uma maior liberdade temática e com a utilização de um novo aparato tecnológico. 
Em 1995, o filme Carlota Joaquina, princesa do Brasil marca o início do chamado Cinema de Retomada que, seguindo os ditames de uma política neoliberal, deve atender às "exigências do mercado".

Desta forma, a indústria cinematográfica, voltada para as produções de massa e aos interesses comerciais, começa a se delinear no Brasil. Um exemplo disto é a criação, em 1997, da Globo Filmes, empresa das Organizações Roberto Marinho especializada na produção de filmes convencionais e sem nenhum lastro crítico que trazem à tela do cinema séries televisivas, adaptações de peças populares de teatro ou ainda de comédias. Todos contam, em seu elenco, com atores que são famosos por atuarem em telenovelas.

Na contramão desta produção, que segue a "lógica do mercado", encontramos filmes regionais, documentários e outros tipos de filme que, mesmo com orçamento baixo, primam pela estética e por questionarem a realidade brasileira. No entanto, são filmes que apresentam dificuldade de entrar no circuito comercial e que, na maioria das vezes, são preteridos em favor de produções hollywoodianas.

Em meio a este contexto, temos a produção do filme Capitães da Areia, que contou com orçamento alto, cerca de 9,2 milhões de reais, já que, em média, o valor gira em torno dos cinco milhões de reais. No Brasil, em geral, as despesas geradas acabam sendo custeadas pelas verbas advindas das leis de fomento à Cultura, o que provavelmente ocorreu com o filme Capitães da Areia, uma vez que ele foi realizado com recursos do programa de chamadas públicas de audiovisual da Secretaria de Estado de Cultura/Rio Filme/Governo do Rio de Janeiro e Prefeitura do Rio de Janeiro, além de ter sido selecionado pelo Programa Petrobrás Cultural e receber apoio federal do Ministério da Cultura e de várias outras instituições públicas e privadas; dois minutos do filme são destinados ao agradecimento a esses apoiadores. 
Outro dado relevante sobre o filme Capitães da Areia diz respeito a sua produção e distribuição. Como produtores, temos Lagoa Cultural e Esportiva, Maga Filmes e, como coprodutores, Laborie Digital e Araçá Azul, uma parceria entre Brasil e Portugal. Em relação aos distribuidores, temos Imagem Filmes e Telecine. Esta última distribuidora faz parte da empresa Globosat, empresa brasileira considerada a maior programadora de TV fechada da América Latina e pertencente às Organizações Roberto Marinho.

Tais fatos nos levam a levantar a hipótese de que a produção do filme possa ter sofrido influências de elementos externos relacionados a espaço de exibição, distribuição entre outros que interferiram na livre autoria da diretora e roteirista da obra, fazendo que os aspectos social e crítico fossem tratados sem maior profundidade.

Vale lembrar, também, que o livro Capitães da Areia compunha a lista de livros de leitura obrigatória para a realização de provas de vestibulares em universidades públicas de peso como, por exemplo, a USP. Tal fato também é garantidor de boa bilheteria.

Ressalta-se, ainda, que o filme foi lançado em outubro de 2011 e já fazia parte dos eventos de comemoração do centenário de nascimento de Jorge Amado (celebrado em 2012). Esse fato também garante a ida do público ao cinema.

Ademais, a diretora e roteirista do filme, Cecília Amado, além de ser neta do autor, também tinha experiência com o roteiro de obras televisivas exibidas pela Rede Globo. Esta experiência reflete no filme ao apresentar a estética das novelas e seriados globais.

Nessa ordem de ideias, podemos dizer que se a adaptação fílmica de Capitães da Areia apresenta certa crítica social, em razão de elementos externos, ela não avança, mostrando-se de forma pouco profunda. Tal fato indicia aspectos relacionados ao mercado interferindo na produção cultural e na sua autoria. 
Segundo Guy Dubord (2009, p. 15),

[...] O espetáculo, compreendido na sua totalidade, é ao mesmo tempo o resultado e o projeto do modo de produção existente. Ele é um suplemento ao mundo real, a sua decoração readicionada. É o coração da irrealidade da sociedade real. Sob todas as suas formas particulares, informação ou propaganda, publicidade ou consumo direto de divertimentos, o espetáculo constitui o modelo presente da vida socialmente dominante. Ele é a afirmação onipresente da escolha já feita na produção, e o seu corolário o consumo. Forma e conteúdo do espetáculo são identicamente a justificação total das condições e dos fins do sistema existente. $O$ espetáculo é também a presença permanente desta justificação, enquanto ocupação da parte principal do tempo vivido fora da produção moderna.

No filme, o combate à desigualdade social pelo engajamento político dos excluídos, veia central do romance, é deixado para segundo plano e focaliza-se mais a temática romântica da obra de partida. Por essa razão, enquanto na obra literária, a constituição do sujeito Pedro Bala se dá pela vivência de experiências coletivas voltadas para a inserção dos excluídos, no filme, através das escolhas estéticas, do roteiro e dos recortes, se potencializa a experiência individual e amorosa de Pedro Bala.

\section{4- O projeto político e estético dos autores em Capitães da Areia e seus diálogos com o tempo histórico}

De forma ampla, pode-se dizer que o projeto político de um autor, ao produzir uma obra, se relaciona a uma tomada de posição perante o mundo e marca o pensamento de um determinado tempo, o que delineia como tal obra se insere no contexto de sua época. Já o projeto estético de uma produção artística se liga às escolhas realizadas no campo da linguagem e, consequentemente, aos efeitos que tais escolhas provocam nos meios tradicionais de expressão. Mas esses projetos não são estanques: eles dialogam intensamente e, por vezes, tornam-se imbricados de tal maneira que não se consegue delimitar suas fronteiras. 
Ao se estudar as obras literária e fílmica Capitães da Areia, é interessante abordar a relação entre estética e política nelas presente, evidenciando como a militância partidária de Jorge Amado e as escolhas estéticas de Cecília Amado marcaram de maneira decisiva a concepção e o formato de suas respectivas produções artísticas.

Jorge Amado, assim como a geração de autores e intelectuais dos anos 30, se engajou no desafio de traçar um retrato da realidade brasileira, buscando compreender sua sociedade, suas instituições, seu Estado, a formação étnica de seu povo, sua cultura; enfim, a identidade nacional do Brasil. Ele faz parte de um quadro de artistas cujas obras refletem o ambiente de cisões ideológicas e as discussões sobre os problemas nacionais. Era tempo de traçar um retrato da realidade brasileira, criticando seus problemas e, ao mesmo tempo, propor uma nova ordem social. A literatura de Amado inova, ao trazer para a cena central do romance, personagens, cenários e temas até então pouco explorados por nossos escritores.

A obra amadiana, além de divulgar a cultura brasileira, também apresenta características ideológicas do socialismo, denunciando as mazelas da sociedade. Assim, o social aparece como um dos elementos centrais das narrativas. Essa vertente da obra amadiana poderia ser explicada pelo fato de Jorge Amado ter entrado para o Partido Comunista do Brasil (PCB) ainda muito jovem e por ter tentado conciliar sua atividade de escritor às demandas políticas dessa organização. O desdobramento dessa aproximação foi a elaboração de um projeto literário que congregou o político e o estético, valendo-se ao máximo do marxismo como base de análise social e de formas e repertórios literários que procuravam inovar e, ao mesmo tempo, criar uma estética que combatesse o conservadorismo literário. Há um comprometimento político e social de Amado, enquanto autor, por meio do discurso presente em sua obra.

Assim, Amado buscou unir, em sua escrita, seus projetos político e estético ao escrever romances com um estilo narrativo que seguia o modelo inflamado dos manifestos 
comunistas, pois tinha intenções doutrinárias, ao mesmo tempo em que colocava no centro da narrativa os excluídos de toda espécie, os grupos mais baixos da hierarquia social. Amado revestiu seus romances para serem os instrumentos de revolução dos excluídos, pois era preciso, primeiramente, implantar um imaginário socialista e angariar o máximo de indivíduos para o partido e se atingisse a tão sonhada utopia da fundação de um Brasil comunista.

Quanto ao seu projeto político, podemos dizer que Jorge Amado visa a retratar a realidade brasileira, denunciando seus desconcertos que, para ele, eram gerados pelo capitalismo. No mais, busca conscientizar o homem de sua função histórica de subverter a ordem social que o oprime.

Ao se posicionar desta maneira, Amado antecipa o entendimento formal da Organização das Nações Unidas de que as questões sociais e coletivas, bem como a expressão individual, são direitos inerentes ao ser humano. Sevcenko (2001, p. 56) lembra que, em 1990, a ONU editava seu primeiro Relatório de Desenvolvimento Humano.

O documento refletia o resultado das pressões da sociedade organizada e de órgãos internacionais ao estabelecer pela primeira vez, de forma categórica, que os direitos humanos incluem não somente os direitos civis e políticos (como estabelecia a tradição liberal), mas também os econômicos, sociais e culturais. Podemos incluir, entre essas pressões, a grande contribuição Arte e da Literatura de várias nações e, no que tange ao Brasil, a grande colaboração de Jorge Amado.

Ao transpor a obra literária Capitães da Areia para o cinema, Cecília Amado procura atualizá-la e, nesse momento de globalização, em que não há mais cisão de um mundo polarizado, a questão ideológica do socialismo é renunciada. No entanto, há uma intenção de se manter a questão social tão bravamente defendida por Jorge Amado. 
Sob essa perspectiva, nota-se a preocupação da cineasta em retratar algumas questões relacionadas à cultura e sociedade brasileira, assim como fez Jorge Amado. A título de ilustração, citam-se as sequências inicial e final da narrativa fílmica que mostram uma celebração à Iemanjá, bem como cenas que, de uma forma muito poética, apresentam rituais do candomblé. A opção por incluir tal questão religiosa na adaptação que, assim como todas as adaptações, precisa fundir, condensar e até preterir episódios inteiros das obras literárias, demonstra uma consonância entre o projeto político dos Amados ao se valorizar a herança cultural e o sincretismo religioso

Também se vê preocupação em abrir espaço e promover o respeito à pluralidade cultural quando se observa as músicas que compõem a trilha musical do filme, uma vez que diversos ritmos - como kuduro, MPB, capoeira, afro-reggae e base de batidas do candomblé coexistem harmoniosamente entre si e com as imagens.

A preocupação social de Jorge também aparece em escolhas da cineasta no processo de produção do filme. Optou-se primeiramente pela atuação de atores não profissionais, todos desconhecidos do público e selecionados por meio de oficinas realizadas em ONGs da periferia de Salvador.

A construção da personagem Dora como uma menina forte capaz de desempenhar, com competência, diversos papéis também mostra a intenção de se valorizar o feminino e de se defender a igualdade de gêneros, intenção essa que permeia muitos dos romances amadianos.

A escolha de se adaptar uma das obras mais publicadas no mundo e que elege menores de rua como protagonistas também revela o desejo da cineasta em levar para as telas do cinema o caráter crítico da obra de partida. 
Essas escolhas podem ser entendidas como desdobramento de uma experiência profissional e, também, pessoal. Profissional porque, ao se analisar o currículo de Cecília Amado, percebe-se que ela colaborou na produção de diversos filmes e séries que apresentam certa crítica social.

Ela iniciou seu trabalho o cinema em 1995, como assistente de continuidade no longa-metragem Tieta do Agreste, de Carlos Diegues. Em 1999, teve sua primeira experiência na direção como segundo assistente em Mauá - O Imperador e o Rei, de Sérgio Rezende. Também trabalhou na televisão como continuísta em minisséries como Dona Flor (1997) e Labirinto (1998), e como assistente de direção na série Cidade dos homens (2004 e 2005). Foi assistente de direção em filmes como Batismo de Sangue, Jogo Subterrâneo e Perigosa Obsessão.

A questão pessoal refere-se à tentativa da cineasta em ser fiel ao avô, com quem conviveu muitos anos depois da publicação da obra Capitães da Areia. É importante ressaltar que há uma confusão entre a figura do avô e a figura do autor.

No entanto, apesar de se perceber a intenção da realizadora da obra cinematográfica em preservar, de alguma forma, a questão social da obra literária amadiana, a obra fílmica, em razão da utilização de recursos estéticos, é retratada com cenas de pouca tensão e eufemiza a complexidade e densidade com que o romance Capitães da Areia desvela a condição dos menores de rua. A estética da beleza e da fantasia muitas vezes toma o lugar da estética da crueza e da feiura, naturalizando e suavizando a questão da exclusão social. 


\section{Capítulo 3 - O diálogo entre os Capitães da Areia dos Amados}

\subsection{Análise comparativa das obras - as escolhas dos autores}

Este capítulo buscará verificar como se processa o diálogo entre as obras artísticas dos Amados, na recodificação criativa do romance para a tela. Visa-se perscrutar em que medida a arte, tanto literária quanto fílmica, engendra reflexos e expressões de uma sociedade e se propõe a descortinar, de alguma forma, seus problemas. Entendemos que, na articulação entre a forma estética e o conteúdo das manifestações artísticas, podemos encontrar uma das chaves de leitura de aspectos importantes da sociedade.

Tanto a literatura quanto o cinema trabalham com códigos e linguagens, no entanto, ambos podem se manifestar como fenômenos reveladores de fatos sociais e se mostram como repositórios de experiências da práxis social.

\subsubsection{As escolhas de Jorge}

Na obra literária Capitães da Areia, Jorge Amado soube amalgamar o estético e o ideológico e compôs uma obra que não pretendia a criação de um imaginário a respeito do passado da nação brasileira como, por exemplo, faziam os escritores do Romantismo, mas sim a elaboração de um ideário comunista para tornar possível a materialização da utopia com a instauração de uma nova ordem harmônica em um futuro vindouro.

Assim, Jorge Amado buscava desvendar a realidade e promover a conscientização crítica do homem a fim de subverter a ordem social opressora. Foi na ânsia pelo Brasil real que o romance Capitães da Areia teria encontrado na produção sociológica um repertório temático e expressivo, já que trata de temas voltados para a elaboração de retratos e 
diagnósticos da realidade brasileira capazes de explicar as razões de parte de nossas mazelas e propor soluções para a inserção do Brasil em um novo tempo.

Ao se filiar ao Partido Comunista, Jorge Amado ajustou seu projeto de escritor às orientações dessa organização e escreveu romances que buscavam retratar o universo dos grupos marginalizados pela sociedade por meio de uma estética que ia ao encontro do modelo defendido pelos manifestos e panfletos comunistas.

Dessa forma, os romances amadianos absorveram o ambiente de cisões ideológicas e os debates sobre os problemas nacionais e colocaram em cena personagens e lugares até então pouco contemplados por nossa literatura.

Sobre a escolha de seus personagens, Jorge Amado afirma na obra $O$ menino Grapiúna que "amigo dos vagabundos, dos mestres de saveiros, dos feirantes, dos capoeiristas, do povo dos mercados e do candomblé. Mais do que isso, fui um deles”. (2010, p. 35).

A obra Capitães da Areia inova ao colocar crianças abandonadas no cerne da narrativa, expediente que não era comum em nossa literatura. É a primeira vez, na literatura brasileira, que meninos de rua são o centro da história. Trata-se de um livro politicamente revolucionário para o momento histórico em que é publicado. Além disso, Amado elege uma dessas crianças para se configurar como um novo herói, deixando de lado aquele herói romântico comprometido com a nossa origem étnica e apresentando um representante dos excluídos.

Dando voz aos marginalizados, Amado propicia que seus personagens tomem consciência política, se construam como indivíduos através de experiências coletivas e se formem como agentes sociais transformadores da realidade. 
No início de sua obra, nós nos deparamos com personagens excluídos e delinquentes, mas que, ao enfrentarem as adversidades provindas de uma sociedade desigual e ainda com o pé no passado colonial, vão se construindo como sujeitos. Suas ações se voltam ao enfrentamento do contexto histórico por eles vivido e incentivam a luta do povo para a tomada de seu lugar no tempo e no espaço.

Entretanto, quando focalizados de perto e individualmente, percebe-se que os personagens de Capitães da Areia não apresentam uma alta densidade psicológica; ao contrário, são caracterizados apenas por um traço marcante, assim como as caricaturas. Essa forma de construir os personagens também se revela como característica importante dos projetos estético e político do autor uma vez que se buscava enfatizar a força da coletividade em oposição ao individualismo. Portanto, tais personagens ganham expressão quando vistos dentro de uma coletividade. Suas ações são, de uma forma geral, resultado de conflitos originários de suas condições de exclusão, estando atreladas ao meio em que vivem. Até mesmo Pedro Bala só adquire status de herói quando seus atos coincidem com as reivindicações do coletivo, do grupo ao qual pertence.

Ao escolher excluídos para serem protagonistas em seus romances, Jorge Amado conquista leitores do povo que passam a se sentir representados por tais personagens, além de se identificar com eles.

Para Antonio Candido (1992, p. 46), Jorge Amado pode ser incluído no movimento chamado "dos escritores do norte" que

[...] surgiu e se colocou, pela primeira vez na literatura nacional, como um movimento de integração, ao patrimônio de nossa cultura, da sensibilidade e da existência do povo, não mais como objeto de contemplação estética, mas de realidade rica e viva, criadora de poesia e ação, a reclamar seu lugar na nacionalidade e na arte. 
Podemos afirmar, portanto, que Jorge Amado deixa de lado os paradigmas da literatura canônica considerada de qualidade para realizar uma obra que mais aproxima da oralidade, do imaginário e dos costumes populares. Para tanto, elegeu entre as figuras do povo seus personagens. São prostitutas, malandros, pescadores, meninos de rua, oprimidos de toda forma que ganham a cena e se apresentam como modelos para uma coletividade.

\subsubsection{Pedro Bala no romance}

Para tratar de herói romanesco, recorremos ao crítico Lukács. Em sua obra A teoria do romance, afirma que o romance corresponde "à epopéia de um tempo em que a totalidade extensiva da vida não é já dada de maneira imediata, de um tempo para o qual a imanência do sentido à vida se tornou problema, mas que, apesar de tudo, não cessou de aspirar à totalidade" (LUKÁCS, 2000, p.61). Para o autor, "a epopeia afeiçoa uma totalidade de vida acabada por ela mesma" (IBIDEM, p. 66). Neste sentido, o mundo impresso pelas epopeias clássicas era homogêneo e pleno de significação. Não havia uma separação entre interioridade e exterioridade o que conferia àqueles homens um sentimento de totalidade. Por essa razão, o herói da epopeia incorpora um destino coletivo e jamais corresponde a um indivíduo isolado em seus dramas pessoais. Portanto, o destino do herói funde-se com o da comunidade épica. Ao passo que, no romance, a representação de mundo passa pela ótica da subjetividade do homem o qual enfrenta diversos problemas dentro da realidade que o cerca.

$\mathrm{Na}$ epopeia, o herói apresenta um caráter primordialmente objetivo como representação de um coletivo enquanto que o herói romanesco é subjetivo e está em constante busca da totalidade, reconciliando-se, dessa forma, com o mundo e consigo mesmo. Sob essa perspectiva, Lukács afirma que a "forma interior do romance é a marcha para si do indivíduo problemático, o movimento progressivo que — a partir de uma obscura sujeição à realidade 
heterogênea puramente existente e privada de significação para o indivíduo - o leva a um claro conhecimento de si" (IBIDEM, p.90).

Em uma realidade fragmentada, o herói romanesco cumpre o destino que lhe foi dado, passando por uma série de provas para, ao final, reencontrar-se. E por meio desse processo de busca que o herói romanesco aprende com as experiências vividas. É a superação da realidade em que vive e a descoberta de um sentido a partir de suas vivências que o reconciliam com o mundo.

Assim, enquanto o mundo do herói está em conformidade e equilíbrio, o mundo do herói romanesco se apresenta de forma fragmentada e em desarmonia com o coletivo.

No tocante a Pedro Bala, temos a construção de um herói romanesco uma vez que se trata de um líder de um grupo de meninos de rua que cometem delitos. Ele se mostra envolvido em um esquema de venda de objetos roubados, gosta de apostar em jogos de cartas e até comete estupros.

O herói construído por Jorge Amado, de acordo com a teoria proposta por Lukács, é problemático, pois tem dificuldade em lidar com a realidade de exclusão que o cerca, ele e o coletivo, a princípio, são dissonantes. A sociedade retratada no romance é bipartida: de um lado está uma elite com seus indivíduos de caráter deformado e interessados apenas em seu bem-estar e, do outro lado, estão os excluídos a mercê de sua própria sorte e lutando de todas as formas para sua sobrevivência.

A problemática do herói, que vai dar origem a sua busca, vincula-se à situação de exclusão dos capitães da areia. Pedro Bala seguirá a jornada do herói romanesco em todas as suas fases e agirá motivado pela ascensão do bem comum, mesmo que para isto tenha que cometer transgressões sociais e macular seu caráter. No romance, Pedro se torna sujeito a 
partir da tomada de consciência da exploração e da opressão a que os menos favorecidos estão submetidos dentro do sistema capitalista e se lança à luta social.

A princípio, Pedro era apenas um do grupo, mas ao se envolver em uma briga com o líder dos meninos, ele alcança o posto de chefe dos capitães.

Não durou muito na chefia o caboclo Raimundo. Pedro Bala era muito mais ativo, sabia planejar os trabalhos, sabia tratar com os outros, trazia nos olhos e na voz a autoridade de chefe [...] Uma noite, quando Raimundo quis surrar Barandão, (Pedro tomou as dores do negrinho e rolaram na luta mais sensacional a que as areias do cais jamais assistiram). Raimundo era mais alto e mais velho. Porém Pedro Bala, o cabelo loiro voando, a cicatriz vermelha no rosto, era de uma agilidade espantosa e desde esse dia Raimundo deixou não só a chefia dos Capitães da Areia, como o próprio areal. Engajou tempos depois em um navio. Todos reconheceram os direitos de Pedro Bala à chefia, e foi desta época em diante que a cidade começou a ouvir falar nos Capitães da Areia, crianças abandonadas que viviam do furto. (AMADO, 2009, p. 27).

Nesse momento, o herói Pedro Bala é chamado à aventura e se entrega a ela. Ele e os capitães se voltam contra os burgueses da Cidade Alta, arquitetam planos e cometem crimes em uma jornada "robinwoodesca". Os delitos praticados são descritos como justos e decorrentes de uma ordem social desigual. Assim, os capitães da areia são vistos como vítimas de uma sociedade opressora e não como criminosos. Seus gestos são descritos como grandiosos. No entanto, esta mesma sociedade opressora, em resposta, coloca a seu favor a atuação dos mecanismos coercitivos do Estado. Os meninos são perseguidos pela polícia, pelo diretor do reformatório e, até mesmo, por uma ala mais conservadora da Igreja Católica.

Expressando uma imensa coragem, Pedro Bala se envolve em várias ações que vão, pouco a pouco, desvelando seu caráter elevado, seu senso de justiça, sua liderança e extrema coragem.

Pedro Bala acordou com um ruído perto de si. Dormia de bruços e olhou por debaixo dos braços. Viu que um menino se levantava e se aproximava cautelosamente do canto de Pirulito. Pedro Bala, no meio do sono em que estava, pensou, a princípio, que se tratasse de um caso de pederastia. E ficou atento para expulsar o passivo do grupo, pois uma das leis do grupo era que 
não admitiriam pederastas passivos. Mas acordou completamente e logo recordou que era impossível, pois Pirulito não era dessas coisas. Devia se tratar de furto. Realmente o garoto já abria o baú de Pirulito. Pedro Bala se atirou em cima dele. A luta foi rápida. Pirulito acordou, mas os demais dormiam,

- Tu tá roubando um companheiro?

O outro ficou calado, coçando o queixo ferido. Pedro Bala continuou:

- Amanhã tu vai embora... Não quero mais tu com a gente. Vai ficar com a gente do Ezequiel, que vive roubando uns dos outros. (AMADO, 2009, p. 45).

-Não vai- repetiu Pedro Bala.

-Porque, meu filho? Perguntou o padre José Pedro.

-Tu sabe, padre, que ninguém volta vivo do lazareto. Ninguém volta, E ele é um da gente, um do grupo. A gente não pode fazer isso...

-Mas é a lei, filho...

-Morrer?

O padre mirou Pedro Bala com os olhos abertos. Aqueles meninos viviam a lhe dar surpresas, sempre mais adiantados em inteligência do que ele pensava. E, no fundo, o padre sabia que eles tinham razão. (AMADO, 2009, p. 145).

Há duas pessoas que não pertencem ao grupo e em quem Pedro Bala confia: o Padre José Pedro, representante da Igreja Católica, e a mãe-de-santo Don'Aninha, representante do Candomblé. Estes personagens atuam como espécies de mentores do nosso herói. São eles que ajudam Pedro Bala a sair de situações conflituosas.

Pedro Bala vai tendo êxitos em suas provações e lutas contra os inimigos. Suas experiências sempre envolvem os capitães e, portanto, são coletivas. E é a partir delas que a consciência crítica de Pedro vai se formando.

Como todo herói romanesco problemático, no entanto, Pedro Bala tem de enfrentar duas situações catárticas para se constituir, finalmente, como sujeito autônomo e agente social.

A primeira situação é sua prisão no reformatório após uma tentativa de roubo a uma residência. Durante o período em que esteve preso, Bala sofreu as maiores torturas: apanhou, 
ficou confinado em um quarto escuro e minúsculo onde quase não podia se mexer, era alimentado com uma comida extremamente salgada e quase nunca bebia água. Mesmo assim, nunca entregou o esconderijo dos capitães e não deu nenhuma informação que pudessem localizá-los, provando a nobreza de seu caráter e seu heroísmo.

A segunda situação se dá com a morte de Dora. A sua dor e perda são tamanhas que ele se joga ao mar para seguir o corpo de sua amada no saveiro do "Querido de Deus" e nada até não mais ter forças, não se importando em morrer. No entanto, a lembrança da valentia de Dora salva-o, fazendo-o voltar para cumprir sua missão. O jovem Pedro renasce naquele momento, como todo herói romanesco.

Outro aspecto relacionado à construção do herói relaciona-se à origem de Pedro Bala. Em meio a uma conversa despretensiosa com João de Adão, Boa-Vida e comadre Luísa, ele descobre que seu pai era Raimundo, o líder dos doqueiros, que morreu liderando uma greve.

- Porque o pai dele era Raimundo e morreu foi aqui mesmo lutando pela gente, pelo direito da gente. Era um homem e tanto. Valia dez destes que a gente encontra por ai (AMADO, 2009, p. 83).

O enaltecimento do pai de Pedro Bala e, portanto, da origem de nosso herói faz com que ele seja equiparado a uma espécie de "semideus". Pedro carrega o gene da transformação, da causa pela qual seu pai morreu e irá honrar esta herança.

A idealização romanesca compõe o retrato modelar do oprimido, o "romance proletário" empresta-lhe uma consciência para impulsioná-lo em sua afirmação como indivíduo. O voo da morte de Sem Pernas, que pula das alturas da cidade rica rumo à cidade baixa, marca o momento agônico do pathos na trajetória do grupo, romanesca descida aos infernos, preparatória à elevação e reconhecimento definitivos dos personagens. Algo semelhante ocorre com Pedro Bala em sua fuga da prisão e no mergulho no oceano acompanhando o cadáver da amada. Com isto, transforma-se também a ação do romance. A recorrência ao substrato mítico - morte e renascimento do herói - emoldura a leitura amadiana da utopia socialista. Mais tarde, a delinquência infantil cede lugar ao engajamento proletário. Os garotos crescem. Mais que isto, são impulsionados do mundo da sobrevivência individual para a rebeldia de uma classe que se levanta. Não será ainda a 
revolução, mas o salto sonhado por Jorge Amado naqueles idos de 37. (DUARTE, 2012). ${ }^{8}$

Pedro Bala, desta forma, é apresentado como um dos meninos - chega à liderança, organiza a atuação dos capitães de forma justa e regrada, ganha fama, descobre sua genealogia de líder, é preso no reformatório onde conhece o inferno, consegue escapar, volta ao inferno com a morte de Dora e ressurge como líder não mais dos meninos, mas do movimento sindical e se constitui como sujeito através da sua tomada de consciência política e de suas experiências coletivas, funcionando como uma espécie de agente da transformação daquele cenário.

Portanto, através de um processo gradual de crescimento fundado nas suas experiências, Pedro Bala consegue deixar sua situação de exclusão e lança o imaginário do jovem politicamente atuante e engajado que irá transformar a situação histórica de desigualdade social e ajudar a construir uma nova imagem de nação brasileira.

Pedro Bala une o individual e o coletivo na sua figura de excluído que se transforma em agente da revolução, buscando não só se reencontrar como também colocar o mundo nos eixos.

Esse modo de interpretação da realidade que enfatiza as hierarquias e as injustiças da sociedade brasileira chama atenção para a vocação doutrinária do romance amadiano, que pregava que as desigualdades só chegariam ao fim quando os indivíduos tomassem consciência de sua identidade proletária e se embrenhassem em lutas pelo coletivo. Por esta razão, Capitães da Areia apresenta, em seu desfecho, um herói que adquiriu sua consciência e solidariedade de classe e volta suas ações para o engajamento em movimentos de greve.

\footnotetext{
${ }^{8}$ Disponível em: <http://www.unicamp.br/iel/memoria/projetos/ensaios/ensaio19>. Acesso em: 15 jan. 2015.
} 


\subsubsection{As escolhas de Cecília}

O projeto de Cecília Amado, de transpor para a tela o livro Capitães da Areia escrito por seu avô, ocorre depois de mais de 70 anos da publicação da obra literária, o que garante à diretora maior liberdade de interpretação do romance, aproximando-o dos discursos em voga na atualidade.

Quanto a esse assunto, Robert Stam (2006, p. 42) afirma:

Em alguns casos, a publicação do romance e a produção do filme ocorrem em momentos muito próximos e diretos. No caso dos mais vendidos, os produtores se apressam para tirar vantagem do sucesso comercial do romance [...] Em outros casos, séculos ou mesmo milênios podem passar entre a publicação do romance original e a produção da adaptação [...] consequentemente, o adaptador desfruta de mais liberdade para atualizar e reinterpretar o romance [...] às vezes, o adaptador inova para fazer com que a adaptação fique mais sincronizada com os discursos contemporâneos.

Em uma entrevista para a revista Caros Amigos, quando questionada sobre sua adaptação fílmica, na qual opta pela década de 50 e não a de 30, como no romance, a diretora respondeu:

O livro foi escrito em 1937, por um Jorge Amado de 24 anos no auge do seu engajamento político. Eu preferi ser fiel ao Jorge que eu conheci, 50 anos depois. Seu olhar era muito mais social do que político. Escolhi a vertente humana do livro, um drama que continua atual. Por isso optei pelos anos 50, de forma a fugir do contexto político e fazer uma fabula quase atemporal ${ }^{9}$.

A opção da cineasta pela década de 50 e não a de 30 torna-se significativa se analisada dentro do contexto histórico da época que pode ser considerado um divisor de águas para a nação brasileira. Nos anos 50, o Brasil se posicionou perante a bipolaridade "socialismo versus capitalismo" e rompeu relações com a antiga União Soviética ao apoiar os Estados Unidos e seu regime capitalista. Por essa razão, o Partido Comunista Brasileiro foi

9 Disponível em: <http://carosamigos.terra.com.br/index/index.php/cultura/noticias/1887-entrevista-cecilia-amado-falasobre-a-producao-do-filme-capitaes-de-areia >. Acesso em: 10 ago. 2012 
fechado e passou a atuar na ilegalidade. Além disso, os governos de Getúlio Vargas e, principalmente, de Juscelino Kubitschek buscaram acelerar o desenvolvimento econômico nacional e fomentaram o processo de industrialização e de construção de uma infraestrutura nacional com o objetivo de inserir o país em um processo de modernização. Com essas mudanças, houve um êxodo rural para os grandes centros urbanos, gerando inchaço das cidades, que cresceram sem planejamento. Esse processo de urbanização pode ser considerado um dos vetores de graves problemas sociais, tais como falta de moradia, precariedade da Saúde e da Educação, saneamento básico deficitário, transporte coletivo incapaz de atender as demandas da população, entre outros.

No mais, essa busca por uma modernização do país gerou a adoção de um padrão de vida próximo ao modelo consumista do capitalismo estadunidense, pois se passou a consumir toda a sorte de utensílios e aparelhos eletrodomésticos.

Para se disseminar essa ideologia modernista e nacionalista, utilizou-se os meios de comunicação como o cinema, a televisão e o rádio, que ganharam espaço e adesão da população.

Neste sentido, a escolha por ambientar o filme em um contexto em que o socialismo perde força e o Brasil abraça o capitalismo mostra claramente a intenção de deixar de lado a discussão política tão manifesta na obra de partida. Essa opção da diretora pode ser interpretada não apenas como uma tentativa de se manter "fiel ao Jorge Amado que conheceu 50 anos depois do lançamento do livro", mas também como um ajuste às exigências da indústria cultural contemporânea que busca fruição da obra artística como entretenimento. Desta forma, para uma obra ser garantidora de bilheteria, ela deve entreter o público e, para tanto, tende a tratar de dramas individuais e preterir assuntos mais críticos e coletivos. No caso de produção artística não se adaptar a essas exigências de "mercado", é comum que haja dificuldade de se conseguir apoio e incentivo a sua produção, distribuição e exibição. Assim, 
elementos externos acabam interferindo na autoria de obras fílmicas que ficam, muitas vezes, a mercê da indústria cultural.

Segundo Ismail Xavier (2005, p.168),

[...] É preciso ultrapassar o nível de um discurso comparativo das várias modalidades de discurso do cinema, para que se possa abordar em profundidade o problema da significação ideológica dos filmes num determinado contexto específico. [...] Se uma determinada modalidade de cinema carrega em sua proposição uma determinada atitude frente ao sistema de distribuição dominante - um pôr-se à margem, um buscar novas formas de produção/difusão, ou um projeto de conquista de uma fatia maior ou menor dentro do sistema- toda uma série de problemas aparecem no momento em que se procura equacionar a natureza das relações entre a modalidade de cinema proposta, as condições de comunicação e a luta econômica. [...]

No filme, foram suprimidas as passagens mais socialistas, bem como trechos

chocantes como, por exemplo, a do estupro de uma menina cometido por Pedro Bala no areal.

Ainda de acordo com Robert Stam (2006, p. 44),

[...] Muitas das mudanças entre a fonte do romance e a adaptação cinematográfica têm a ver com ideologia e discursos sociais. Nesse sentido, a questão é se uma adaptação empurra o romance para a "direita", ao naturalizar e justificar hierarquias sociais baseadas em classe, raça, sexualidade, gênero, religião e nacionalidade, ou para a "esquerda" ao questionar ou nivelar as hierarquias. Há também "desenvolvimentos desiguais" a esse respeito, por exemplo, em adaptações que empurram o romance para a esquerda em algumas questões (como classe), mas para a direita em outras (como gênero e raça). Adaptações cinematográficas frequentemente "corrigem" ou "melhoram" o texto original, de formas muito diferentes e até contraditórias. Os filmes contemporâneos de Hollywood tendem a ser fóbicos em relação a qualquer ideologia vista como "extrema", seja ela proveniente da esquerda ou da direita. As adaptações hollywoodianas frequentemente "corrigem" suas fontes ao extrair delas o que é controverso - como o lesbianismo em A Cor Púrpura - ou revolucionário - como o socialismo em Vinhas da Ira - ou difícil - como a técnica reflexiva em Lolita - ou anticinematográfico - as passagens filosóficas em Moby Dick.

Portanto, a busca por adequar a adaptação cinematográfica aos discursos sociais contemporâneos, a necessidade de enquadramentos para obter patrocínio e garantir a distribuição e a exibição da obra no circuito comercial e, também, a busca pessoal da diretora em representar o pensamento do avô e autor do obra de partida - que, anos depois da 
publicação desta, se desencantou com a ideologia socialista - são os três vértices que podem justificar as mudanças realizadas na transposição fílmica no que se refere à supressão da ideologia socialista presente o romance, bem como quanto à escolha por ambientar a obra em um tempo diferente daquele da narrativa fílmica.

\subsubsection{Os personagens na obra cinematográfica}

No tocante à forma de construção dos personagens no filme, pode-se observar que o combate à desigualdade social pelo engajamento político dos excluídos, veia central do romance, é tratada com outro enfoque - já que os holofotes se voltam para a história de amor de Pedro Bala e Dora.

Além disso, pode-se dizer que a narrativa fílmica não explora de maneira tão contundente como a narrativa literária o traço caricatural de cada um dos capitães. No filme, ocorre uma espécie de planificação dos meninos já que, em sua maioria, são retratados como pequenos malandros que cometem delitos por diversão enquanto que, no romance, eles são tipos como o líder, o intelectual, o rebelde, o sedutor, o religioso, o preguiçoso, entre outros, que vivem entre a ordem e a desordem, sendo que seus atos ilícitos são justificados pela situação de exclusão em que vivenciam.

Ensinam-nos Cunha e Baseio (2012, p. 4), em Capitães da Areia, que:

[...] As personagens são apresentadas como um leque de diversidades e contradições: Pedro Bala exerce sua liderança, protege seus companheiros, mas o faz dentro de uma suposta ética da marginalidade; o Professor diverte o grupo contando histórias, tem sua imagem associada àquele que professa uma verdade, mas sua verdade se faz do roubo de outros; Pirulito é o mais religioso do grupo, entretanto assalta a igreja. Habitantes das fronteiras entre a ordem e a desordem, essas personagens têm seus nomes motivados por alguma característica física, psicológica ou social. 
Na obra de partida, a história, apesar de seguir uma linearidade, é contada em função da trajetória dos capitães que, por obra do destino ou em razão das experiências vividas, deixam de viver à margem da sociedade. Já a adaptação concentra-se em contar a história de amor de Pedro e Dora, tratando pouco das ações dos outros personagens. As mudanças pelas quais eles passam acontecem, geralmente, por acaso, como que por ação de um deus ex machina e as mais consistentes e importantes são apenas profetizadas pela voz off em uma das cenas finais do filme. Portanto, apesar de os capitães estarem em movimento, vivenciando experiências, há uma progressão tímida, diferente do ritmo e do movimento de superação estabelecidos no romance.

Ademais, há diversas cenas em que as ações dos personagens são mostradas através de um fluxo acelerado, quase imitando a estética do videoclipe. No entanto, apesar de os personagens estarem em movimento, suas ações não se convertem em saber narrável, pois, parece que eles se movem incessantemente, mas progridem muito pouco.

Ao assistir ao filme, portanto, nota-se que há um movimento excessivo dos personagens, mas que, se analisado profundamente, não se converte em conhecimento, como ocorre no romance. Esta peculiaridade do filme o remete à tradição baudelairiana do flâneur, citada por Walter Benjamim (1989). Para ele, a figura do flâneur seria espécie de alegoria da crise na transmissibilidade da experiência.

Os personagens na obra cinematográfica se distanciam dos personagens romanescos da obra literária e se constituem de forma que suas ações se deparam com o vazio experimentado pelo homem momento histórico atual. Logo, assim como o flanador de Walter Benjamin, os personagens de Cecília Amado, apesar de estarem deslocados da sociedade, em um lugar à margem, não apresentam uma visão crítica da realidade de que fazem parte nem mostram consciência política e compreensão do fenômeno histórico em que estão inseridos. 
Desta maneira, eles agem como ébrios que nada enxergam com clareza e andam pelas ruas desorientados, fazendo malandragens.

Como estão deslocados, eles, mesmo sendo crianças e adolescentes, rememoram em algumas cenas seu passado, acreditando que este era um tempo em que havia esperança. A cena do carrossel, por exemplo, mostra a fuga dos personagens para o tempo mágico da infância, mesmo que esse tempo exista apenas na imaginação de muitos deles, mas que lhes devolve a possibilidade da infância e do sonho. Essa cena consegue retratar a busca dos personagens pela infância não só pela utilização da iluminação colorida e onírica do carrossel, mas pela utilização da câmera lenta, pela ausência de diálogos apenas e, também, pela canção

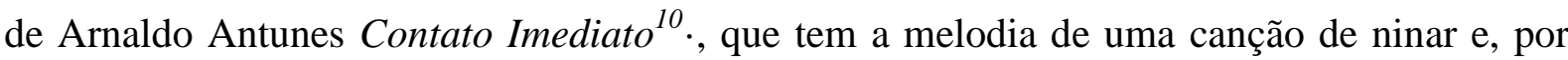
fim, pela voz off e doce de uma mãe que conta histórias para seu filho antes de ele adormecer.

A rua conduz o flanador a um tempo desaparecido. Para ele, todas são íngremes. Conduzem para baixo, se não para as mães, para um passado que pode ser tanto mais enfeitiçante na medida em que não é o seu próprio, o particular. Contudo, este permanece sempre o tempo de uma infância. (BENJAMIN, 1989, p. 185).

A escolha da diretora Cecília Amado por enquadrar os personagens como pequenos malandros e, também, por construí-los dentro de um movimento incessante, mas que não os leva a lugar algum, pode ser analisada como parte de um projeto estético e ideológico pautado na crítica de uma realidade injusta que é fruto de um processo histórico, baseado na alienação, que impôs uma modernidade excludente a qual não esboça qualquer possibilidade de superação destes esquemas hegemônicos de exclusão.

10 Trecho da música Contato Imediato, de Arnaldo Antunes: Peço por favor/Se alguém de longe me escutar/Que venha aqui pra me buscar/Me leve para passear/No seu disco voador/Como um enorme carrossel/Atravessando o azul do céu/Até pousar no meu quintal. 
Desta maneira, pode-se dizer que Cecília Amado, através da construção dos personagens realiza uma obra de resistência, mas sem transmitir explicitamente um posicionamento político.

Nessa perspectiva, ensina-nos Bosi (1998, p. 129) que é importante:

[...] aprofundar o campo de visão. E detectar em certas obras, escritas independentemente de qualquer cultura política militante, uma tensão interna que as faz resistentes, enquanto escrita, e não só, ou não principalmente, enquanto tema.

\subsubsection{O herói Pedro Bala nas telas}

A marginalidade social que permeia o romance Capitães da Areia centraliza-se em um grupo de crianças excluídas que tenta resistir a uma lógica perversa, resistência que se personifica em Pedro Bala. É ele quem, com sua bravura e coragem, torna-se peça chave para o desenvolvimento da trama.

Sem apresentar características psicológicas densas, tanto o romance quanto o filme constroem a figura de um herói romanesco que lidera os capitães da areia, mantendo a harmonia entre os meninos. Em relação à obra cinematográfica, nota-se que Pedro vivencia experiências mais pessoais e não chega a se constituir como sujeito coletivo já que o filme se debruça mais sobre as aventuras e desventuras do amor do herói por Dora e sobre as relações de amizade e de liderança que o herói estabelece com os outros capitães, deixando de lado as tensões sociais e políticas exploradas pela obra de partida.

Desta forma, o narrador retrata o herói como o líder que apazigua os conflitos, que garante negociatas para a garantia de recursos para os capitães e que é o mantedor das regras de convivência entre eles. Não há um aprofundamento, pela narrativa fílmica, capaz de delinear significações não imediatas decorrentes de sua caracterização física ou psicológica. 
Diferentemente do romance, em que a complexidade das relações sociais, culturais e políticas assume maior destaque por meio das ações Pedro Bala, dando destaque à coletividade, na obra cinematográfica se prioriza o indivíduo e seus dramas já que se optou pela não atenuação do caráter político da obra literária. Há uma tentativa de se questionar alguns aspectos da realidade, entretanto, essa crítica não avança.

O engajamento político de Pedro Bala não se concretiza no filme e em apenas algumas cenas há a menção sobre certo comprometimento social do herói, como é o caso de uma das cenas da sequência final em que Professor profetiza sobre o destino dos capitães da areia. Ao falar de Pedro Bala, diz que seguirá o destino dele, irá ajudar os meninos na sua luta mais importante, a luta pela liberdade: "Não vai ter gente que ele não ajude, vai ser como o pai e organizar todos os meninos da Bahia. Todo mundo vai parar para ouvir ele. Vai lutar pelo que tem mais importante na vida: a liberdade".

Enquanto Professor fala em off, a câmera centra-se em Pedro Bala carregando uma imagem de Iemanjá junto com outras pessoas na praia. O fato de ser uma cena externa e com iluminação branca nos transmite uma sensação de liberdade, mas a ideia do que seria essa luta pela liberdade fica vaga.

Portanto, enquanto no romance a constituição do sujeito Pedro Bala se dá pela vivência de experiências coletivas voltadas para a inserção dos marginalizados, no filme, através das escolhas estéticas, do roteiro e dos recortes, potencializa-se a experiência individual e amorosa de Pedro Bala.

\subsubsection{A linguagem do romance}

Um aspecto estrutural muito importante da obra literária Capitães da Areia, e que é, ao mesmo tempo, um traço característico da literatura de Jorge Amado, é o modo como o 
escritor recorre ao trabalho com a linguagem. Ao utilizar-se de um hibridismo linguístico em que combina a linguagem coloquial e muito próxima da oralidade, repleta de gírias e expressões utilizadas pelo povo, com a linguagem de registro culto, com construções refinadas, ele faz refletir na obra o embate social entre pobres e ricos de forma contundente. Deste modo, não há como negar a confluência entre forma e conteúdo: a linguagem usada na narrativa é parte integrante da crítica tecida pelo autor.

A narrativa inicia com uma reportagem cuja manchete é "Crianças ladronas", que narra um crime dos capitães da areia - "o grupo de meninos assaltantes e ladrões que infestam a nossa urbe" - contra um rico negociante. Na sequência, são apresentadas cinco cartas enviadas à redação do Jornal da Tarde, de Salvador, em que se debate o problema dos “meninos de rua”. A primeira Carta é do Secretário do Chefe de Polícia; a segunda, do Juiz de Menores; a terceira, de uma mãe, costureira, que ataca o Reformatório; a quarta é de um personagem da trama que defende os meninos - o Padre José Pedro; a última é a do Diretor do Reformatório.

Esse painel jornalístico nos apresenta um conjunto de vozes e forças que se chocam, pois caminham em direções diversas e, na maioria das vezes, opostas. Jorge Amado inova ao abrir espaço para que todos se manifestem, criando uma polifonia. Desta forma, vozes dissonantes se apresentam e são ouvidas dentro de um quadro social. Há aquelas que trazem a norma culta, como a do Juiz de Menores, por exemplo, e as que trazem um tom coloquial e popular, como a da costureira. Na fala do narrador, ora aparecem construções da variante padrão e de prestígio - revelando um narrador onisciente, que de tudo sabe e narra aparentando estar indiferente aos fatos -, ora surgem coloquialismos, desvios sintáticos e o discurso indireto livre, evidenciando, numa voz híbrida, ser solidário aos meninos do Trapiche. 
A introdução confere lastro de realismo e objetividade à narração e aos fatos a serem revelados, por se tratar de um veículo comprometido em documentar a realidade. Tal estratégia, importante para mostrar a contradição social que nos enovela, insere o leitor em um ambiente em que ficção e realidade se confundem.

O uso recorrente da linguagem popular poderia nos fazer pensar que a literatura amadiana era elaborada de forma fácil e descuidada. No entanto, Jorge Amado fez da linguagem das ruas uma forma de revolucionar a arte já que contrariava os padrões de redação literária da época, os quais ditavam que a escrita deveria observar a gramática e não poderia apresentar traços de oralidade.

- Tá pensando que tem treita? Pode espiar. Eu faço jogo limpo.

Mas veio um sete e depois um dez e então veio um valete. O Gato arrastou a mesa, enquanto Pedro fazia uma cara de grande aborrecimento e dizia:

- Amanhã, quando o peso te pegar, tu vai ver que te arraso,

O baixo confessou que estava limpo. O de bigodinho meteu as mãos no bolso:

- Tou só com os níqueis pra pagar a cerveja . O garoto é um braço. (AMADO, 2009, p.51).

Antigamente aqui era o mar. Nas grandes e negras pedras dos alicerces do trapiche as ondas se rebentavam fragorosas, ora vinham se bater mansamente. A água passava por baixo da ponte sob a qual muitas crianças repousavam agora, iluminadas por uma réstia amarela de lua [...] (AMADO, 2009, p.25).

Assim, é por meio de uma linguagem simples e entremeada por construções refinadas que o autor de Capitães da Areia cria uma sintaxe própria que vai representar, de forma documental e poética, os meninos de rua dos grandes centros urbanos e suas mazelas.

Essa subversão aos padrões convencionais mostra-se como uma adesão ao modo de pensar e falar das personagens da história e manifesta-se como mais uma estratégia de combate às facetas opressoras da sociedade.

Segundo Carelli (1997, p. 186),

[...] Para Jorge Amado, que assumia o rótulo de escritor comunista, a simplificação da forma era uma meta a atingir, não importando o quanto de "suor", muito ou pouco, fosse vertido na composição das obras. O objetivo 
dos escritores do partido era "escrever sobre o povo, para o povo". A linguagem complexa e hermética das vanguardas não servia para eles, pois, se a adotassem, só seriam compreendidos pela elite cultural e econômica que queria justamente combater.

Na obra em questão, vemos que os períodos compostos por coordenação e os períodos simples, bem como as enumerações, conferem ritmo cinematográfico ao conto, com direitos a cortes de tomadas.

Saiu, cerrando a porta. O Sem-Pernas ficou parado, sem um gesto, sem responder sequer o boa-noite, a mão no rosto, no lugar em que dona Ester o beijara. Não pensava, não via nada. Só a suave carícia do beijo, uma carícia como nunca tivera, uma carícia de mãe. Só a suave carícia no seu rosto. Era como se o mundo houvesse parado naquele momento do beijo e tudo houvesse mudado. Só havia no universo inteiro a sensação suave daquele beijo materno na face do Sem-Pernas.

Depois foi o horror dos sonhos da cadeia, o homem de colete que ria brutalmente, os soldados surravam o Sem-Pernas, que corria com a perna aleijada em volta da saleta [...] (AMADO, 2009, p. 123).

Portanto, alguns desvios da norma culta em relação à regência, colocação pronominal, bem como repetição de conjunções, são traços próprios da linguagem oral e revelam não uma falta de capacidade intelectual, mas um respeito à voz da camada social da população que não era nem ouvida nem respeitada. No mais, conferem à obra um dinamismo muito próximo ao do cinema.

De acordo com a visão do crítico Eduardo Assis Duarte, grande parte da crítica adotou um posicionamento redutor ao considerar a ficção amadiana maniqueísta e superficial, contrapondo-se a outra corrente que exaltava a nova forma de Amado escrever sobre e para o povo, adotando uma linguagem marcada pela oralidade, recuperando "modalidades dos falares populares que o romance brasileiro até então fora incapaz de incorporar ou o fizera de modo excessivamente estilizado”. (DUARTE, 1996, p. 12).

Desta forma, a linguagem de Capitães da Areia aparece mais livre de regras, mais espontânea, despojada e, portanto, com expressividade na construção dos personagens. Jorge 
Amado aproxima, na obra, a linguagem literária à fala brasileira, incorporando gírias, palavrões e erros gramaticais. Além disso, tal tipo de linguagem aproxima a ficção do gosto do público e, ainda, apresenta um caráter documental já que retrata o povo e a sua linguagem.

Portanto, a linguagem com que se narra Capitães de Areia estabelece uma apropriação - de caráter político - da linguagem falada pelos excluídos com suas transgressões gramaticais e oralidade. O uso dessa variante linguística dá voz à classe marginalizada, garantindo a ela um grau de autonomia essencial à conquista da identidade cultural do Brasil. A opção de retratar a fala popular é uma tentativa de recriar uma linguagem que rompesse padrões e favorecesse a desalienação social.

\subsubsection{A linguagem dos atores na obra cinematográfica}

Quanto à linguagem utilizada pelos atores no filme, nota-se que houve empenho da diretora em manter uma linguagem informal e natural, o que preservou o traço característico da obra original. Em entrevista ao jornal $O$ Globo, Cecília Amado relata como tentou conseguir esse efeito ao afirmar que os atores "nunca receberam roteiro. Fizemos uma leitura coletiva porque eu queria um pouco de improvisação nas cenas, que eles dissessem frases naturais, orgânicas" 11 .

Como resultado, temos falas típicas da linguagem oral cuja construção retrata o português falado na Bahia (como podemos perceber pelo modo de construção frasal em que há a colocação do advérbio de negação "não" depois do verbo ou a inversão dos termos das orações, por exemplo) entremeado de gírias, palavrões e palavras de baixo calão e de conotação sexual.

11 Disponível em: <http://oglobo.globo.com/cultura/cecilia-amado-lanca-em-utubro-longa-metragem-inspirado-no-bestseller-capitaes-de-areia-publicado-por-seu-avo-em-1937-2705628\#ixzz3Ae4BLzXD>. Acesso em: 8 set. 2014. 
Essas marcas estão presentes em cenas iniciais, como podemos observar abaixo nas transcrições das falas de algumas cenas do filme. ${ }^{12}$

Cena em que Pedro Bala distrai um homem bem vestido para que Professor furte a carteira dele:

Professor- E aquele homê ali, Bala?

Bala- Bora.

Vendedor- Aqui tem a cura pra todos os males. Sarna, catarro, agonia de mulher, queixume de velho, espinhela caída, bebedeira, unheiro, intestino solto, intestino grosso...

Pedro Bala- E pra coragem tem? Aquelas coragens assim de homem pra a hora do vamo vê.

Vendedor-e cê tem idade pra isso, rapaz?

Pedro Bala - Claro!

Vendedor- Então, tenho aqui pra você um preparado especial. Vai jurubeba, catuaba, casca de...

Homem bem vestido- E boldo? Tem?

Vendedor - Boldo não é bom pra isso, não.

Pedro Bala- Fiquei até com medo, e se dé um revertério.

Vendedor- ah, ai já não é comigo. Vô logo avisando, viu? Na minha barraca, aqui é tudo natural, não tem contraindicação. Se não fizer bem, mal também não faz.

\section{Cena em que Boa Vida conversa com vendedora de laranja.}

Saveirista- Oh, Boa Vida, vai fica de fuzuê? Venha me ajudar, venha.

Boa Vida- O Bala mandô fica aqui. Daqui não saio, Vô fica aqui com Dona Luísa.

Boa Vida- Ow, Dona Luísa, me arranja uma laranja ai, vai? Tô cuma fome danada.

D. Luísa- E você já viu laranja enche barriga de ninguém, menino?

Boa Vida - Enche...Uma só... Me dá ai...

D. Luísa- Vô escolhe aqui uma boazinha pra você.

Boa Vida- Ow, Dona Luísa, até que a senhora tá cuma peitama bem boa, viu? Durinha.

D. Luísa- Menino, você é muito do safado, viu? Você não tá vendo que tenho idade pra sê sua, não.

Boa Vida- Ah, meu Deus, eu cuma vó dessas! Mas é com todo respeito, viu, Dona Luísa?

D. Luísa- Duvido...você só podia ter nascido na Bahia. Viu, Boa Vida?

Boa Vida- Em outro lugar não caberia.

Dona Luísa- Não caberia mesmo. Toma ai sua laranja.

Boa Vida- Obrigada, Dona Luísa.

12 Transcrição nossa. 


\section{Cena em que Sem Pernas discute com Gato}

Sem Pernas- Só tu pra arriscá cadeira pra rouba um anel feio da porra desses, Gato.

Gato- Achei decente.

Sem Pernas- Tá achando que vai ganhá a vadia com esse anel, é?

Gato- Cê que vir mais eu, Sem Pernas? Pra vê se alguma mulhê te qué assim, coxo?

Sem Pernas- Amostra a veca pra vê se ela te qué, neném.

Gato- Neném, seu merda? E assim?

Sem Pernas- É neném, sim. Vai, comedor de puta.

Gato - E você tem alguma, tocador de punheta?

Sem Perna- Vai pegá puta.

Gato- Você pega só aquela veia lá. Você não pega ninguém.

Pedro Bala- Opa, cheguei na hora do cacete. Vamo entrá que tenho um serviço pra ti, Sem Pernas.

Vemos que os diálogos, na obra cinematográfica, apresentam palavrões. Tal uso ganhou, pela primeira vez, destaque nos filmes brasileiros na época do Cinema Novo e do Cinema Marginal que propunham o que se denominou antiestética já que a intenção desses movimentos artísticos era denunciar a realidade social através de uma estética que explorasse o feio, o violento, o escatológico e, desta forma, chocasse o público.

Desde 2001 é possível notar que alguns cineastas brasileiros vêm revisitando essa antiestética inaugurada por tais movimentos artísticos ao tratar, de forma transgressora, de temas como a exclusão social e a violência urbana. Filmes como Cidade de Deus (2002), de Fernando Meirelles, Contra Todos (2004), de Roberto Moreira, Amarelo Manga (2002), de Cláudio Assis, e Tropa de Elite (2007), de José Padilha, são exemplos de que o cinema brasileiro atual vem procurando tocar em questões sociais, mas de uma forma diferente da do Cinema Novo e Marginal. Emprega-se alguns traços daquela estética mas, muitas vezes, sem realizar uma análise mais aprofundada da situação, o que pode gerar a espetacularização da violência e da pobreza, por exemplo.

Não se pode negar que houve um crescimento de filmes que privilegiam essa estética transgressora tanto no campo narrativo quanto no audiovisual. Desta forma, o antiestético dos 
anos 60 ganha outros contornos no cinema contemporâneo. E o palavrão é um dos exemplos disso.

Embora a narrativa fílmica Capitães da Areia privilegie a estética do belo ao adotar grande quantidade de panorâmicas e apresentar trabalho primoroso de fotografia, em algumas passagens, ela revisita os movimentos do Cinema Novo e do Cinema Marginal, incorporando traços dessa antiestética como, por exemplo, no uso recorrente de palavrões no diálogo entre os personagens. E, apesar de a obra fílmica ter como personagens principais menores de rua, não se pode dizer que esta é a temática do filme nem que se constrói uma análise aprofundada sobre tal tema.

E mesmo com a adoção de alguns recursos estéticos transgressores, tais como linguagem, cenas de violências, ritmo acelerado, algumas músicas e sons que criam desconforto, a crítica social trazida pelo filme se apresenta de forma discreta.

\subsection{Jorge Amado do Folhetim?}

Desde os primeiros romances amadianos, a linguagem próxima da oralidade, a repetição e o formato de folhetim foram considerados, por uma parte da crítica, elementos desqualificadores de sua obra. Por essa razão, esse quinhão crítico aponta que o estilo do autor não promoveria uma inovação. Para outra vertente, contudo, esses mesmos elementos são responsáveis pelo valor de sua obra e, principalmente, pela aceitação e formação de um público leitor brasileiro, com a qual se identificava.

Especificamente quanto à estrutura folhetinesca, é possível que Amado tenha percebido que o alto teor sentimental e dramático dado a uma obra pudesse funcionar como chave para conquistar a adesão do leitor, levando assim a leitura às camadas populares. Desta 
forma, essa característica pode ser entendida como uma escolha estética atrelada aos projetos político e literário do autor.

Esse poder de "ganhar o leitor" e promover a leitura está presente desde o nascimento do gênero "folhetim". Como se sabe, o romance de folhetim surgiu na França no século XIX, em pleno Romantismo, e se expandiu para outros países. Essa nova forma de se fazer literatura impulsionou o crescimento do público leitor, bem como promoveu a transformação da leitura, cuja prática era restrita a uma minoria. Com o advento do romance de folhetim tornou-se mais democrático o acesso aos livros, conforme afirma Jean-Yves Mollier.

Reproduzível ao infinito, ou quase, o que não acontecia com o romance vindo antes dele, o folhetim destruiu as estruturas das livrarias tradicionais, pulverizou os limites do antigo leitorado, fez recuar as fronteiras de que separavam a população provida de livros do povo privado de material impresso. Capaz de adentrar em quase todos os lares, ele se tornou um elo entre as gerações de leitores, a base ou o centro de uma cultura comum e o ponto de partida da uniformização, ainda que relativa, das culturas nacionais até então extremamente separadas.

Seu triunfo foi inegável e sua capacidade de superar todos os outros gêneros anteriores na preferência do público foi surpreendente [...]

Sua irradiação internacional imediata, sua faculdade de fazer surgir, senão de criar, literaturas nacionais, demonstram sua força mesmo que ele permaneça, ainda hoje, um gênero literário desdenhado, quando não desprezado pelas instituições acadêmicas. (MOLLIER apud CASTRO, 2012, p. 8).

Entretanto, grande parte da crítica o considera um gênero inferior em razão de estar ligado à literatura de massas e ao seu modo melodramático, o que confeririam ao texto pouco valor literário, conforme podemos observar pelas afirmações de Massaud Moisés sobre o gênero.

O romance-folhetim se caracterizava por desfiar quilômetros de episódios emanharadamente convencionais e por um sentimentalismo piegas. Como tais novelas bucólicas e sentimentais da Renascença e fim da Idade Média, alimentava a imaginação do leitor menos exigente, assim cumprindo uma função que hoje é desempenhada pelas novelas de televisão e filmes de cowboys. 
O folhetim de natureza literária ou não se difundiu por toda parte, incluindo Portugal e Brasil, sobretudo enquanto durou a psicose romântica, vários escritores cultivaram-no como Garret, Camilo, Alencar, Machado e outros. (MOISÉS, 1985, p. 232).

Apesar das críticas, não se pode deixar de reconhecer a contribuição do gênero para a literatura no que diz respeito à circulação de livros, ao estímulo à leitura e à definiçãa dos contornos das literaturas nacionais. E, quanto à estética do gênero, por ser ela muito variada, cometeríamos um equívoco se afirmássemos que todos os romances de folhetim não apresentam inovação estética.

Nessa perspectiva, ensina-nos Castro (2012, p. 23) que

[...] A par do desprestígio do romance-folhetim, diversos escritores, inclusive aqueles considerados "realistas" ou "naturalistas" tais como Balzac e Zola, tiveram seu quinhão na produção folhetinesca dos "mistérios", comprovando o êxito da fórmula e a importância de sua realização para a evolução do gênero romanesco.

É importante destacar que o romance de folhetim se caracteriza por ser repleto de lances imprevistos, múltiplas peripécias, reviravoltas, triângulos amorosos, traições, violência, final nem sempre feliz, maniqueísmo, personagens tipificados, entre outros elementos. Nele, muitas vezes, o autor recorre a um artifício denominado de deus ex machina, pelo qual se introduz repentinamente um evento, uma revelação, um artefato ou um personagem para desemaranhar a trama sem levar em consideração sua lógica interna.

A fórmula francesa de folhetim, desde sua origem, voltou-se para o pequeno burguês e para as classes trabalhadoras. Esses segmentos da sociedade se reconheciam nos personagens e liam por entretenimento.

Ademais, pode-se dizer que o gênero folhetim fez sucesso por apresentar uma leitura fácil que propiciava ao leitor uma evasão de sua realidade, seguindo a fórmula do melodrama da luta do Bem contra o Mal que se apoia em despertar, no leitor, sentimentos como medo, dor, entusiasmo, prazer, etc. 
O mundo, no melodrama, se apresenta de forma cartesiana e maniqueísta, separado de forma esquemática entre o Bem e o Mal. Esse traço das produções melodramáticas mostra seu papel pedagógico de ensinar aos indivíduos o certo e o errado dentro de uma ótica burguesa. Assim, o folhetim, seguindo a tradição do melodrama, conta histórias dos maus que, em um primeiro momento, desfrutam de boa vida e se dão bem, muitas vezes aparentando honestidade, enquanto os bons sofrem todo tipo de má sorte. Mas há um momento em que ocorre a inversão da situação e o Bem triunfa.

Encontramos traços do romance de folhetim na obra Capitães da Areia, de Jorge Amado. Primeiramente, os capítulos são curtos - remetendo-nos aos de um folhetim - e contam as peripécias dos meninos de rua, seguindo a forma de publicação desse gênero, com suas necessidades de cortes e de dividir-se em fragmentos - sem que se perca a impressão de totalidade - a fim de instigar no leitor a vontade de continuar lendo.

No mais, há uma dicotomia entre pobres e ricos que permeia todo o enredo e se desdobra em fracos versus forte, crianças versus sociedade opressora, pontuando em todo romance uma presença de contrastes.

Os relógios badalavam as três horas da tarde e a cidade abafava de calor quando o jardineiro notou que algumas crianças vestidas de molambos rondavam o jardim da residência do comendador. $\mathrm{O}$ jardineiro tratou de afastar da frente da casa aqueles incômodos visitantes. (AMADO, 2009, p. $10)$.

Também temos o casal romântico Pedro Bala e Dora que, em meio a uma paixão arrebatadora, precisa superar inúmeros obstáculos para viver feliz. Entretanto, por obra do destino e seguindo uma tradição camiliana, esse amor é interrompido de forma trágica pela morte de Dora.

Agora limpava os lábios dele, estava curvada na sua frente, seu rosto bem próximo do de Bala, os cabelos loiros misturados com os dele.

-Por que foi a briga?

-Por nada. 
-Diga...

-Ele disse umas coisas..

- Foi por causa de mim, não foi?

Ele abanou a cabeça afirmando. Então ela chegou os lábios para junto dos de

Pedro Bala, os beijou e depois fugiu. (AMADO, 2009, p. 187).

Há ainda a sugestão do triângulo amoroso Bala, Dora e Professor, no melhor estilo

folhetinesco.

Pedro Bala olhou os dois. Suspendeu o boné, sentou na areia. Mas Dora o olhava com carinho. Para ele... Para ele era tudo: esposa, irmã e mãe. Sorriu confuso para Dora:

-Pensei que fosse ser uma tentação pra todos...

Ela fez que não, ele continuou:

-Depois podiam aproveitar uma hora que a gente não estava...

Riram. Professor repetiu mais uma vez:

-Não. É como uma mãezinha...

-Tu pode ficar - disse Pedro Bala, e Dora sorriu pra ele, era herói, uma figura que ela nunca tinha imaginado, mas que um dia haveria de imaginar. Amava-o como a um filho sem carinho, um irmão corajoso, um amado tão belo como não haveria outro.

Mas Professor viu os sorrisos dos dois. E disse ainda mais uma vez com voz sombria:

-É como mãe!

Dizia com voz soturna, porque, para ele, ela também não era mãe. Também para o Professor ela era a amada. (AMADO, 2009, p.182).

Não faltam, no romance, cenas de violência extremas, como o episódio do estrupo de uma menina cometido por Bala no areal, bem como a passagem em que Pedro Bala é torturado no reformatório.

Pedro não respondia. Conhecia outras que faziam chiquê. Em geral porque tinham um amante a esperá-las. Nem por um momento pensou que a negrinha fosse virgem. Mas ela resistia e o xingava, e mordia, batia suas frágeis mãos no peito de Pedro Bala. [...]

Ele suspendeu as saias pobres de chita, apareceram as duras coxas da negra. Mas estavam uma sobre a outra e Pedro tentou separá-las. (AMADO, 2009, p. 89-90).

Ouviu o bedel Ranulfo fechar o cadeado por fora. Fora atirado dentro da cafua. Era um pequeno quarto, por baixo da escada, onde não se podia estar em pé porque não havia altura, nem tampouco estar deitado ou comprido, porque não havia comprimento. Ou ficava sentado, ou deitado com as pernas voltadas para o corpo numa posição mais que incômoda [...] Seus membros doíam, ele tinha vontade doida de estiraçar as pernas. Seu rosto estava cheio de equimoses das pancadas da polícia, e desta vez Dora não estava ali ara trazer um pano frio e cuidar do seu rosto ferido. (AMADO, 2009, p. 197). 
A obra também apresenta de forma crua e direta temas como pederastia, prostituição e crimes cometidos por crianças a mercê de uma espécie de determinismo social.

O conflito que move o romance é basicamente folhetinesco: pobres contra ricos, fracos contra fortes, pequenos marginais contra a sociedade opressora. O insólito do folhetim se materializa nos rostos angelicais, porém malvados; nos gestos inocentes encobrindo ou propiciando o roubo, a trapaça, o estrupo. A violência, elemento caro ao roman-feuilleton, decorre do quadro de enfrentamento social vivido pelo protagonista e seu grupo. Ela é muitas vezes gratuita, outras tantas necessárias ou mesmo justa, segundo o código de valores da narrativa. Todavia sempre choca, visando a provocar emoções primárias de terror, piedade ou admiração. A violência é meio de ação dos mocinhos-bandidos, mas é também fim nas típicas atitudes de vingança do aparelho repressivo: sede, fome, espancamento, clausura... Em todo o texto, é enfatizado o sentido melodramático de pureza infantil "abandonada e perseguida" no labirinto da cidade degradante e degradada. (DUARTE, 1996, p.114).

E também há passagens que se destacam pela abordagem extremamente aberta e chocante, mostrando o lado animalesco e degradante de alguns personagens. Esse expediente também é típico de obras melodramáticas e é utilizado, muitas vezes, para "ganhar" o leitor. Como é o caso do episódio em que Sem-Pernas se infiltra na casa de uma "solteirona" para roubá-la e ela o aborda no meio da noite para praticar atos libidinosos com o menino. Pode-se dizer que esse episódio choca o leitor, primeiramente, por se tratar de uma figura feminina que comete a licenciosidade, o que não era comum na literatura brasileira e, também, porque a obra oferece ao leitor uma descrição detalhada do episódio, sem qualquer pudor. Desta forma, esse expediente melodramático, ao mesmo tempo em que surpreende, conquista a atenção do leitor.

Era uma coisa incompleta que enraivecia Sem-Pernas. A solteirona gemia baixinho de amor. Apertava a cabeça do Sem-Pernas contra seus seios enormes, o sexo dele contra suas coxas, a mão do menino no seu sexo. (AMADO, 2009, p. 231).

Outro expediente comum a folhetins, e também encontrado na obra literária Capitães da Areia, é o emprego de elementos místico-religiosos para se justificar certos 
acontecimentos, como por exemplo, a epidemia de varíola, que é explicada no romance como sendo um desígnio do deus Omolu.

Omolu tinha mandado a bexiga negra para a Cidade Alta, para a cidade dos ricos. Omolu não sabia da vacina, Omolu era um deus das florestas da África, que podia saber de vacinas e coisas científicas? (AMADO, 2009, p.139).

Por fim, há uma falta de nexos causais plausíveis já que o narrador, por diversas vezes, lança mão do acaso para justificar certos acontecimentos importantes para dar continuidade à narração, o que pode gerar um efeito de superficialidade como quando Dora e seu irmão Zé Fuinha ficam órfãos e a menina o deixa sozinho em uma praça e sai em busca de algo para comerem. Ao voltar com um pedaço de pão, o menino havia saído do lugar combinado e estava conversando com Professor, o qual, num espaço curto de tempo, fica sabendo e se sensibiliza com a história dos irmãos e se propõe a quebrar a regra do grupo de não aceitar meninas.

Pode-se perceber, portanto, que Jorge Amado utiliza-se da estrutura do folhetim e, dessa forma, coloca em prática seu projeto estético e político, apesar de essa estrutura ser considerada conservadora. Esse foi o caminho encontrado pelo autor para levar literatura às massas com o intuito de disseminar um imaginário comunista no país e chamar o povo para a revolução. Segundo Carelli (1997, p.188), “Jorge Amado sempre procurou falar diretamente a um número cada vez maior de leitores embora isso pudesse significar na maioria das vezes uma crescente simplificação formal e uma repetição temática em suas obras”.

Como vimos, o romance Capitães da Areia segue uma estrutura de folhetim provavelmente para conquistar um público maior de leitores, principalmente os das camadas mais baixas da população. Esse tipo de obra apresenta muitas características propicias ao argumento de um filme convencional, espelhado em Hollywood, tais como: equilíbrio inicial, ruptura, "purgatório", encontro providencial, suspense, etc. Além disso, tem-se a trajetória do 
herói que triunfa no final como algo fundamental para dar à ficção a dramaticidade ideal necessária para se conquistar o espectador.

\subsection{Cecília Amado e sua aproximação ao cinema clássico hollywoodiano}

Apesar de a adaptação fílmica de Cecília Amado ser uma obra independente e autônoma, ela se vale das características folhetinescas da obra de partida e adota a estrutura do cinema clássico hollywoodiano.

No que se diz respeito ao cinema clássico hollywoodiano, é importante ressaltar que sua forma narrativa, do jeito que a concebemos hoje, foi inaugurada apenas em 1915. Após sua instauração, começou-se a seguir alguns princípios que, de acordo com Vanoye e GoliotLété (2005), podem ser resumidos na homogeneização do significante visual (cenários, iluminação), do significado narrativo (relações legendas e imagens, desempenho dos atores, unidade do roteiro: história, perfil dramático, tonalidade de conjunto) e do significante audiovisual (sincronismo da imagem e dos sons: palavras, ruídos, música), bem como na linearização, ou seja, no modo como se vincula um plano ao plano seguinte: vínculo no olhar (um personagem olha e enxergamos o que ele enxerga), vínculo no som (ouve-se um ruído em um plano, identifica-se sua fonte no plano seguinte), etc. Além disso, há uma maior flexibilidade da câmera, além de uma recorrência do uso de close-ups, do uso de figuras de montagem como, por exemplo, a "alternada", que permite o desenvolvimento simultâneo de dois ou mais eventos, ou da técnica do insert, pela qual um primeiro plano de detalhe que, em uma cena, informa algo essencial ao espectador ao mesmo tempo em que reforça um impacto dramático.

Fazendo uso desses princípios e novas técnicas, o filme poderia proporcionar ao espectador o maior número possível de elementos para que o mesmo pudesse acompanhar a 
narrativa, garantindo coerência, clareza e a linearidade desse ato de narrar. De modo geral, na narrativa clássica, o encadeamento das cenas e das sequências se desenvolve de acordo com uma dinâmica de causas e efeitos clara e progressiva (VANOYE; GOLIOT-LÉTÉ, 2005, p. 27).

Desta forma, o cinema clássico hollywoodiano se caracteriza também por apresentar certa previsibilidade, ou seja, o espectador sabe desde o início que, de uma forma ou de outra, o protagonista triunfará no final.

No que se refere à temática abordada, pode-se afirmar que os filmes clássicos de Hollywood tratam dos mais variados assuntos e, por essa razão, não há um tema importante do qual eles não tenham se ocupado ao longo da história dessa indústria. A retratação de assuntos como dramas familiares, relacionamentos amorosos, guerras, entre outros, segue, em geral, a estrutura convencional: começo, meio, fim e uma mensagem facilmente reconhecível pelo espectador.

Não se pode negar que o cinema clássico americano criou uma espécie de manual de discurso narrativo, com uma série de códigos de linguagem, e se tornou modelo para as produções cinematografias de todo o mundo, sendo exemplo não só na sua forma de produção e realização como também na de representação, que passou a povoar o imaginário ocidental. Desta forma, a narrativa clássica hollywoodiana constrói-se por meio do emprego de códigos sonoros e visuais que sintetizam um verdadeiro manual de discurso narrativo cujo objetivo é criar verossimilhança com a realidade.

Nesse sentido, poderíamos dizer que o cinema clássico tem servido de modelo de produção de muitos filmes, bem como de modelo de um discurso ideológico que foi sendo enraizado socialmente em um processo contínuo que vem desde a sua instalação. 
Podemos ver vários elementos do modelo de cinema clássico hollywoodiano na obra fílmica Capitães da Areia. Primeiramente, escolheu-se a sequência cronológica para contar a história nas telas. Assim, a estrutura fílmica é organizada em começo, meio e fim, respeitando a sequencialidade normal dos eventos narrados.

Além disso, no filme, os significantes narrativo e audiovisual estão em harmonia e sincronia, gerando linearidade e previsibilidade que levam o telespectador a acompanhar o desenrolar da história sem maiores esforços.

Também há a utilização de vários planos, com certa predominância dos médios e americanos, que transmitem a sensação de que o telespectador participa da cena, demonstrando familiaridade e dramaticidade corporal, e dos planos gerais, revelando cenas criadas para fruição de um efeito estético.

Em relação à temática, esta se centra no relacionamento amoroso de Pedro Bala e Dora com todos os seus percalços, seguindo a forma melodramática das comédias românticas de Hollywood.

A estrutura de filme tradicional também se revela em algumas cenas como as de lutas entre os capitães da areia e o grupo de Ezequiel e, também, dos meninos do reformatório e os guardas. Nessas cenas, há a opção de um ritmo acelerado e de diversos cortes aliadas a uma trilha sonora, imitando a estética do videoclipe.

Sugere-se que a escolha pela estrutura do filme clássico hollywoodiano vai ao encontro da estrutura de folhetim adotada pelo romance. Ambas escolhem mostrar, explicar de forma simples. Ao analisar as narrativas literária e fílmica, percebemos que elas tendem a mostrar a cena e não a narrar; isto quer dizer que, em vez de traduzir as impressões, opiniões e valores dos personagens através de recursos estilísticos que velem as mensagens, preferem, 
em sua maioria, abrir espaço para que eles se manifestem tornando a obra facilmente entendida por seus leitores ou telespectadores e, consequentemente, atingindo maior público.

Tais escolhas da diretora, por uma forma mais próxima da estrutura do cinema clássico hollywoodiano, indicam que ela tenha seguido as recomendações recorrentes na maioria dos manuais de roteiros popularizados na atualidade. Neste sentido, afirma Robert Stam (2006, p. 45) que:

[...] Muitas adaptações televisivas ou das tendências dominantes de Hollywood fazem o que pode ser chamado de uma "adequação estética às tendências dominantes". Os vários manuais populares sobre como escrever roteiros e adaptações são bastante esclarecedores nesse sentido. Seja qual for o romance original, a maioria dos manuais mostram uma aversão radical a todas as formas de experimentação e modernismo. Quase invariavelmente, eles recomendam jogar a fonte na direção do modelo dominante de contar histórias (seja no modelo clássico de Hollywood ou de Sundance, sua versão mais amenizada). O modelo aristotélico reciclado e suburbanizado dos manuais de roteiro recorrem a estruturas em três atos, conflitos principais, personagens coerentes (e muitas vezes simpáticos), um "arco" narrativo inexorável e catarse final ou final feliz [...] Tudo se torna subordinado a uma teleologia tão implacável quanto o destino da tragédia clássica. O objetivo parece ser "desliteralizar" o texto, uma vez que o romance passa por uma máquina de adaptação que remove todas as excentricidades autorais ou os "excessos".

Embora tenha adotado a forma do cinema clássico, a obra fílmica apresenta alguns aspectos estéticos que fogem a esse modo tradicional de produzir filmes e introduz certos elementos que poderiam representar a tentativa de manutenção da crítica social referente à desigualdade social que está contida na obra de partida.

Ressalta-se que não se trata de transpor para o filme o posicionamento políticoideológico presente no romance, mas talvez de se tentar, por meio de procedimentos estéticos, chamar atenção para o problema social dos menores de rua.

Um dos procedimentos que corroboram essa hipótese mencionada é a utilização de uma técnica de filmagem que se aproxima da estética neorrealista italiana, a qual objetivava, 
no momento histórico em que surgiu, retratar de forma crítica a realidade europeia do pósguerra.

O Neorrealismo italiano, segundo Fabris (2006, p. 78-79),

[...] mais do que oferecer modelos estéticos, vinha fornecer uma atitude moral, ao mostrar como debruçar-se sobre a realidade local, principalmente sobre o mundo popular, com um novo olhar. Ao valorizar a postura ética sobre a técnica, as teorias neorrealistas (sobretudo as de Cesare Zavattini) [...] foram um elemento deflagrador a mais na busca incessante de uma identidade nacional.

Assim como a proposta neorrealista, a obra cinematográfica de Cecília Amado privilegiou o uso de locações reais, de atores não profissionais, do improviso e, também, de algumas cenas com ambiente pouco iluminado. Tais escolhas não podem ser vistas como aleatórias e, provavelmente, representam a intenção da diretora de imprimir a marca, na narrativa fílmica, da crítica social presente na maioria das obras amadianas e, também, de construir um retrato da identidade regional e, também, nacional brasileira.

Outras escolhas estéticas também indicam a tentativa de o filme manter, mas de outra forma, a crítica social tão pormenorizada no romance. Em primeiro lugar, apesar de a problemática do menor abandoado não ser a questão central da adaptação cinematográfica, ela aparece em segundo plano. Vemos os capitães em ação, mas em ambientes e em condições precários, sujeitos a doenças, ao abandono material e intelectual e, por vezes, à perseguição pelas autoridades locais para que se adequem ao mundo da ordem. Assim, a obra fílmica, ainda que não tenha aprofundado esse problema da exclusão social de crianças em primeiro plano, ela sutilmente traça um retrato das condições em que vivem esses menores.

Outro aspecto estético que sugere uma tentativa de se provocar o telespectador e chamar sua atenção para a situação de exclusão em que vivem os capitães é a peculiaridade, na filmagem, de algumas cenas que são mostradas por meio de registro acelerado. 
Primeiramente, focaliza-se um personagem e, em um ritmo rápido, passa-se para outro, criando uma sensação de vertigem e incômodo ao telespectador. Ao gerar essa desorientação e retirar o telespectador de sua posição de conforto (que a estética do cinema clássico hollywoodiano garante), o filme provoca o espectador a refletir sobre alguma questão que, no caso de Capitães da Areia, poderia ser a exclusão social presente na realidade brasileira.

Também há, no filme, o emprego de metonímias. Usa-se o close-up para focalizar apenas partes de personagens ou de objetos, o que sugere que há uma dificuldade, na contemporaneidade, de se enxergar o conjunto. A realidade é mostrada de forma fragmentada e os indivíduos acabam enxergando somente parte de um todo muito mais complexo.

Outra peculiaridade estética da obra cinematográfica, e que pode ser interpretada como tentativa de se construir uma crítica social, encontra-se na filmagem de algumas cenas que apresentam imagem acelerada que, entretanto, são exibidas em ritmo lento. Esse aspecto estético, além de ilustrar o contraditório, confere a tais cenas a sensação de alucinação como, por exemplo, a sequência que mostra Pedro Bala na cafua do reformatório. Há uma confusão entre o que é realidade e rememoração do que é delírio e imaginação. A sequência que mostra a chegada do carrossel na cidade e o encantamento das crianças ao admirá-lo e experimentá-lo também é filmada com o uso desse recurso e sugere a oposição da infância, tempo que passa lento e pode ser fruído, com a maturidade precoce e opressora, mostrando a tirania da sociedade que retira o direito à infância das crianças excluídas.

Em relação à iluminação, emprega-se a contraposição do claro (luz amarelada) e escuro para retratar a oposição entre pobres e ricos, transpondo, nesse caso, o maniqueísmo do livro. As cenas do filme em que os capitães estão no seu ambiente, em seu abrigo, a iluminação é baixa e amarela e apenas clareia parte do rosto dos meninos; todo o espaço é escuro como se não existisse, sugerindo que os menores vivem em um lugar à parte da sociedade. Entretanto, quando a cena se passa na casa dos personagens abastados, todo o 
ambiente, com seus respectivos objetos de valor e proprietários, são iluminados por uma luz branca, dando uma sensação de imagem fidedigna do real pelo apuro descritivo da cena. Já sobre os capitães recai uma sombra que os mantém à margem daquele ambiente. Como exemplo, pode-se citar a cena em que Sem-Pernas está na casa de Dona Esther e a câmera focaliza a decoração, a empregada de uniforme, os adornos da casa e ao fundo se ouve música clássica, caracterizando, além da época histórica, a posição social dos personagens. A escolha por dar enfoque a esses objetos e personagens indica a intenção da obra cinematográfica de registrar a oposição entre a classe abastada que pode existir e os excluídos que vivem nas sombras e parecem invisíveis.

Ainda em relação à iluminação, há a associação, na cena final do filme, da luz branca ao ideal de liberdade pelo qual Pedro Bala irá lutar. A luz remete à liberdade e esta, por sua vez, está associada a uma liberdade genérica que pode se referir tanto a uma liberdade de credo (valorização do candomblé como sendo uma das formas de representação da Bahia) quanto a uma liberdade de raça, já que o ator que dá corpo a Pedro Bala é um representação da miscigenação brasileira, bem como a uma liberdade de expressão, porque se é livre para expor pensamentos e opiniões, e a uma liberdade do indivíduo que consegue, por seu esforço, superar o determinismo social, já que a ele é dado escolhas. No filme, Pedro Bala pode decidir o caminho que quer trilhar.

A narrativa fílmica optou por não associar a constituição de Pedro Bala, como indivíduo, a seu engajamento nos movimentos sindicais e socialistas, ou seja, diferentemente da obra de partida, o herói não se torna sujeito pelo seu envolvimento em causas coletivas. Assim, preferiu-se retratar a superação da exclusão como resultado de seu esforço pessoal e que sua luta seria por um ideal amplo de liberdade (que é bem maior das sociedades democráticas contemporâneas). Tal escolha da cineasta pode ser interpretada como uma tentativa de adequação do discurso da narrativa aos discursos da atualidade. 
Outra característica estética do filme, que pode estar associada a uma intencionalidade da cineasta Cecília Amado de, por meio de sua obra cinematográfica, traçar um retrato da realidade brasileira, é a escolha das cores que compõem os cenários do filme. Utilizam-se cores primárias e fortes como o vermelho e o amarelo para mostrar a Bahia e seus bens culturais (a baiana vendendo acarajé, as feiras, os rituais do candomblé). Ao se retratar o país e sua cultura com essas cores, constrói-se um retrato da identidade nacional baseado no olhar da cineasta. Tal intenção pode ser constatada em um artigo em que Cecília Amado declara:

O Brasil precisa começar a exportar cinema com força para mostrar sua cinematografia e o próprio país ao mundo, assim como fizeram e fazem a Itália e a França. A temática do atual cinema brasileiro é muito variada [...] Os filmes produzidos aqui não falam somente de violência, favelas e meninos de rua, embora esses assuntos estejam presentes nas telas por fazerem parte da realidade do país. ${ }^{13}$

Portanto, Cecília Amado valeu-se de elementos do romance de cunho melodramático e voltado para o público de massa para transpor para as telas a obra Capitães da Areia e, para tanto, adotou o modelo clássico hollywoodiano, o qual comumente recorre a tais elementos para construir suas narrativas. Entretanto, sua obra apresenta aspectos estéticos peculiares que não se enquadram em modelos de filmes clássicos, o que pode ser interpretado como uma tentativa de provocar o telespectador e chamar a sua atenção para questões sociais da realidade brasileira, principalmente a problemática do menor excluído e, dessa forma, manter a crítica social presente na obra literária amadiana. Entretanto, a sua crítica não progride: ela aparece sutilmente e em segundo plano. A narrativa apresenta a infância de meninos pobres e sem voz, colocando à mostra suas artimanhas ilícitas para sobreviver. Assim a narrativa fílmica, diferentemente do livro,

13 Disponível em: <http://oglobo.globo.com/cultura/cecilia-amado-lanca-em-utubro-longa-metragem-inspirado-no-bestseller-capitaes-de-areia-publicado-por-seu-avo-em-1937-2705628\#ixzz3Ae4BLzXD>. Acesso em: 8 set. 2014. 
apresenta uma abordagem menos militante, focalizando os temas do amor, da amizade e da liberdade.

\subsection{O Foco Narrativo: olhares sobre o mundo}

Segundo Todorov, qualquer que seja a narrativa, ela apresenta dois aspectos, pois é, ao mesmo tempo, história e discurso. É história porque evoca certa realidade, acontecimentos que teriam ocorrido, personagens que, de certa forma, se confundem com os da vida real. E é ao mesmo tempo discurso, pois existe um narrador que relata a história e, em seguida, um leitor que a percebe. Neste sentido, para o teórico "não são os acontecimentos relatados que contam, mas a maneira pela qual o narrador nos fez conhecê-los". (TODOROV, 1973, p. 211).

Nesse sentido, a focalização e a figura do narrador são, nas narrativas, elementoschave para a configuração do que Ingarden (apud BELLO, 2008, p. 271) denominou de “perspectivação adotada pelo realizador da obra". Assim, não importa o gênero da narrativa; ela é contada sempre a partir de um olhar sobre o mundo. No mais, tem como um de seus elementos essenciais o narrador, ou seja, aquela instância que nos coloca em contato com a história, às vezes se mostrando e participando das ações em conjunto com os personagens, outras vezes sem sequer ser identificável.

O conhecimento dos fatos da história pelo narrador também varia de narrativa para narrativa. De acordo com o sistema de igualdades e desigualdades proposto por Todorov (apud GAUDREALT; JOST, 2009) esse narrador pode saber mais que os personagens, o mesmo que os personagens ou menos que os personagens. Todas essas particularidades estruturais corroboram a construção da focalização. 
Muito se teorizou sobre narrador e focalização. Entretanto, cada estudioso defende o emprego de determinados termos e ideias, o que torna a terminologia sobre o assunto complexa e, muitas vezes, confusa.

De forma a não se entrar na discussão teórica sobre nomenclatura, elegeram-se algumas definições. Narrador onisciente é aquele que conhece toda a história e pode transmitir pensamentos e emoções dos personagens. Narrador limitado é aquele que só apresenta um conhecimento parcial da história. No tocante à sua participação na diegese, o narrador será interdiegético se fizer parte do universo ficcional, ou extradiegético caso não fala parte deste universo.

Nas narrativas literárias, são as escolhas do narrador, de seus movimentos, das características físicas e psicológicas dos personagens, dos acontecimentos que são narrados e sob qual ângulo, da linguagem, do tempo, do que se conta e do que se esconde que denunciam qual o olhar sobre o mundo que a obra retrata.

Já as narrativas fílmicas, por se configurarem como um produção visual, trabalham com a imagem aliada ao som e, ao unir essas duas categorias, criam um significado que reflete um ponto de vista. Ao apresentar uma perspectiva sobre o mundo, os filmes tentam direcionar o olhar do espectador com uma intenção: de este aderir a esse mesmo ponto de vista. Esse direcionamento do nosso olhar seria um dos elementos chaves que afirmam cada filme como expressão viva de uma intenção (XAVIER, 2005, p.54).

De acordo com Pudovkin (apud Xavier, 2005), o cinema traduz em imagem e dá expressão visual a uma representação da consciência que atentamente observa o mundo que nos rodeia. Nesse sentido, afirma Xavier (2005, p. 67) que:

[...] atingir no cinema uma representação dos fatos compatível com o modelos proposto pelo realismo crítico significa, necessariamente, compor um universo ficcional apto a colocar os fatos narrados em perspectiva e capazes de organizar suas relações de modo a que se produza um efeito 
específico: a imagem e o som não se combinam com o objetivo de mostrar algo mas com o objetivo de significar algo; o que implica na apresentação do fato, não como um ato de testemunho[...], mas em nome de uma compreensão de seu significado histórico." E conclui afirmando que "por trás de qualquer realismo ou antirrealismo (em suma, de qualquer estética, está sempre uma posição ideológica.

Nas obras cinematográficas, a construção desse olhar decorre, muitas vezes, do movimento de câmera, de determinadas angulações, do sentido especial de determinados planos, da iluminação, da música ou sons, e da montagem.

Assim, tanto as narrativas literárias quanto as fílmicas retratam um olhar sobre o mundo, e a diferença quanto as suas respectivas focalizações tem a ver com a natureza de seus meios de expressão.

\subsubsection{O olhar sobre o mundo nas folhas dos Capitães}

A obra literária Capitães da Areia é narrada em $3^{\text {a }}$ pessoa, através do discurso indireto livre, já que o narrador é onisciente, isto é, tem acesso às ações e, também, ao fluxo de consciência das personagens. Há também abertura para o discurso direto, com a apresentação dos diálogos entre as personagens. Conforme vemos, na passagem transcrita abaixo:

O padre José Pedro espiou as roupas do Boa-Vida e riu. Boa-Vida olhou também para seus trapos:

-É que meu pai morreu, sabe? Mas até num colégio estive... Tou falado a verdade. Pra que é que eu ia roubar essa coisa? - apontava o relicário Demais numa igreja. Não sou pagão.

O padre José Pedro sorriu de novo. Sabia perfeitamente que Boa- Vida estava mentindo. Há muito que ele aguardava uma oportunidade para travar relações com as crianças abandonadas da cidade [...] (AMADO, 2009, p. 70).

Em relação ao foco narrativo, podemos dizer que, como ele acompanha os capitães da areia, seu centro de consciência se desloca pelos meninos que fazem parte do grupo, 
focalizando, em cada momento da narrativa, um dos personagens, apesar de Pedro Bala se constituir como o protagonista.

Nos prefácios de suas obras, Henry James chamava atenção para a importância do ponto de vista nas obras ficcionais. Para ele, o ponto de vista da narrativa funcionaria como uma espécie de "método de manipulação" e elege como ponto de vista ideal o único, ou seja, aquele centralizado no interior de um determinado personagem. Entretanto, em Capitães da Areia não há um personagem específico para ser o refletor das ideias do narrador e sim a eleição da coletividade como centro de consciência. Tal escolha, feita de forma consciente ou não pelo narrador, está de acordo com o momento histórico e artístico no qual se enfatiza a coletividade, deixando de lado os dramas e as soluções individuais.

Desta forma, a história em Capitães da Areia se conta pelos olhos dos meninos de rua, marginalizados pela sociedade, haja vista a impossibilidade de, no mundo moderno, se apresentar apenas um ponto de vista totalizante. Apesar de o centro de consciência se fundar na coletividade, ela a cada momento acompanha um dos meninos, revelando sua personalidade e seus dramas internos.

Temos, aqui, a primeira contradição do romance, pois o centro de consciência se propõe a refletir uma coletividade, mas adota o procedimento de individualizar cada um deles ao caracterizá-los pelo seu traço mais marcante, ou seja, de forma caricatural e também expor marcas de sua personalidade, característica inaugurada pelo romance oitocentista; antes do aparecimento deste, a literatura não se ocupava do indivíduo e de seus dramas.

Quanto ao narrador, apesar de ele ser de $3^{\text {a }}$ pessoa, não há distanciamento nem objetividade em relação ao centro da consciência uma vez que ele adere à causa dos meninos. Já no prólogo, intitulado Cartas à Redação, temos indícios da tomada de posição do narrador 
a favor dos capitães da areia. Esta parte se inicia com uma notícia a respeito do grupo de meninos que pratica pequenos furtos e aterroriza a elite da cidade de Salvador.

CRIANÇAS LADRONAS
AS AVENTURAS SINISTRAS DOS “CAPITÃES DA AREIA"- - A
CIDADE INFESTADA POR CRIANÇAS QUE VIVEM DO FURTO -
URGE UMA PROVIDENCIA DO JUIZ DE MENORES E DO CHEFE DE
POLÍCIA - ONTEM HOUVE MAIS UM ASSALTO
Já por várias vezes o nosso jornal, que é sem dúvida o órgão das mais
legítimas aspirações da população baiana, tem trazido noticias sobre a
atividade criminosa dos "Capitães da Areia", nome pelo qual é conhecido o
grupo de meninos assaltantes e ladrões que infestam a nossa urbe. Essas
crianças que tão cedo se dedicaram à tenebrosa carreira do crime não têm
moradia certa ou pelo menos a sua moradia ainda não foi localizada. Como
também ainda não foi localizado o local onde escondem o produto dos seus
assaltos, que se tornam diários, fazendo jus a uma imediata providência do
Juiz de Menores e do doutor Chefe de Polícia. (Amado, 2009, p. 9).

Amado inova ao apresentar essas cartas em uma espécie de prólogo. Trata-se de uma expediente criativo que, além de conferir certo lastro de veracidade, verossimilhança e confiabilidade à narrativa, transforma-se em um espaço democrático em que há a expressão e a comunhão de diversos segmentos da sociedade. Aqui, a obra se configura como coletiva.

Tal expediente também irá definir a motivação para a narração e contornar parte que está por vir. Logo nas primeiras linhas, percebemos que a notícia peca pela parcialidade já que apresenta o ponto de vista de um dos lados que movem a história que será narrada, o lado dos detentores do poder e controladores dos meios de comunicação.

Na sequência, há a apresentação de diversas cartas enviadas à redação do jornal se manifestando a respeito da notícia publicada. Temos cartas do secretário do chefe de polícia, do juiz de menores, de uma costureira, de um padre e do diretor do reformatório.

Ao final de cada carta, há um comentário entre parênteses localizando o espaço do jornal em que cada carta foi publicada e se houve manifestação de apoio ou não a ela. Estes comentários, que não levam sinal de autoria, revelam, através da ironia, uma tomada de posição em favor dos meninos. 


\section{CARTA DO SECRETÁRIO DO CHEFE DE POLÍCIA À REDAÇÃO DO JORNAL DA TARDE}

"Sr. diretor do Jornal da Tarde

Cordiais saudações.

Tendo chegado ao conhecimento do doutor chefe de polícia a reportagem publicada ontem na segunda edição desse jornal sobre as atividades dos "Capitães da Areia", bando de crianças delinqüentes, e o assalto levado a efeito por este mesmo bando na residência do comendador José Ferreira, o doutor chefe de polícia se apressa a comunicar à direção deste jornal que a solução do problema compete antes ao juiz de maiores que à policia. A polícia neste caso deve agir em obediência a um pedido do doutor Juiz de Menores. Mas que, no entanto, vai tomar sérias providências para que semelhantes atentados não se repitam e para que os autores do de anteontem sejam presos para sofrerem o castigo merecido.

Pelo exposto fica claramente provado que a polícia não merece nenhuma crítica pela sua atitude em face desse problema. Não tem agido com maior eficiência porque não foi solicitada pelo juiz de menores.

Cordiais saudações.

Secretário do Chefe de Policia.”

(Publicada em primeira página do Jornal da Tarde, com clichê do chefe de polícia e um vasto comentário elogioso) (Amado, 2009, p. 13).

CARTA DE UMA MÃE, COSTUREIRA, À REDAÇÃO DO "JORNAL DA TARDE"

"Sr. Redator:

Desculpe os erros e a letra pois não sou costumeira nestas coisas de escrever e se hoje venho a vossa presença é para botar os pontos nos ii. Vi no jornal uma notícia sobre os furtos dos "Capitães da Areia" e logo depois veio a polícia e disse que ia perseguir eles e então o doutor dos menores veio com uma conversa dizendo que era uma pena que eles não se emendavam no reformatório para onde ele mandava os pobres. É pra falar no tal do reformatório que eu escrevo estas mal traçadas linhas. Eu queria que seu jornal mandasse uma pessoa ver o tal do reformatório para ver como são tratados os filhos dos pobres que têm a desgraça de cair nas mãos daqueles guardas sem alma. Meu filho Alonso teve lá seis meses e se eu não arranjasse tirar ele daquele inferno em vida, não sei se o desgraçado viveria mais seis meses. O menos que acontece pros filhos da gente é apanhar duas e três vezes por dia. O diretor de lá vive caindo de bêbedo e gosta de ver o chicote cantar nas costas dos filhos dos pobres. Eu vi isso muitas vezes porque eles não ligam pra gente e diziam que era para dar exemplo. Foi por isso que tirei meu filho de lá. Se o jornal do senhor mandar uma pessoa lá, secreta, há de ver que comida eles comem, o trabalho de escravo que têm, que nem um homem forte agüenta, e as surras que tomam. Mas é preciso que vá secreto senão se eles souberem vira um céu aberto. Vá de repente e há de 
ver quem tem razão. E por essas e outras que existem os "Capitães da Areia".

Eu prefiro ver meu filho no meio deles que no tal reformatório. Se o senhor quiser ver uma coisa de cortar o coração vá lá. Também se quiser pode conversar com o Padre José Pedro, que foi capelão de lá e viu tudo isso. Ele também pode contar e com melhores palavras que eu não tenho.

Maria Ricardina, costureira.

(Publicada na quinta pagina do "Jornal da Tarde", entre anúncios, sem clichês e sem comentários). (Amado, 2009, p. 16).

É clara a convergência de opiniões daqueles que detêm o poder em oposição à convergência de opiniões dos excluídos e de uma ala da Igreja Católica.

Ao iniciar a narrativa, o narrador demonstra, através das escolhas linguísticas, do lirismo e da forma humanizada de descrever cada um dos capitães, sua posição favorável aos meninos.

Vestidos de farrapos, sujos, semi-esfomeados, agressivos, soltando palavrões e fumando pontas de cigarro, eram, em verdade, os donos da cidade, os que a conheciam totalmente, os que totalmente a amavam, os seus poetas. (Amado, 2009, p. 27).

Há parágrafos extensos em que os discursos dos meninos ou de personagens que apoiam os capitães (como o Padre José Pedro e Don'Aninha), ao invadirem o discurso do narrador, se plasmam a ele, mostrando o não distanciamento entre narrador e personagens. E, muitas vezes, expressões de sentimentos dos meninos se misturam às do narrador.

O Sem-Pernas ficou parado, olhando. Pirulito não se mona. Apenas seus lábios tinham um lento movimento. O Sem-Pernas costumava burlar dele, como de todos os demais do grupo, mesmo de Professor, de quem gostava, mesmo de Pedro Bala, a quem respeitava. Logo que um novato entrava para os Capitães da Areia formava uma ideia ruim de Sem-Pernas. Porque ele logo botava um apelido, ria de um gesto, de uma frase do novato. Ridicularizava tudo, era dos que mais brigavam. Tinha mesmo fama de malvado. Uma vez fez tremendas crueldades com um gato que entrara no trapiche. E um dia cortara de navalha um garçom de restaurante para furtar apenas um frango assado. Um dia em que teve um abscesso na perna o rasgou friamente a canivete e na vista de todos o espremeu rindo. . Muitos do grupo não gostavam dele, mas aqueles que passavam por cima de tudo e se faziam seus amigos diziam que ele era um sujeito bom. No mais fundo do seu coração ele tinha pena da desgraça de todos. E rindo, e ridicularizando, 
era que fugia da sua desgraça. Era como um remédio. Ficou parado olhando Pirulito, que rezava concentrado. No rosto do que rezava ia uma exaltação, qualquer coisa que ao primeiro momento o Sem-Pernas pesou que fosse alegria ou felicidade. Mas fitou o rosto do outro e achou que era uma expressão que ele não sabia definir. E pesou, contraindo seu rosto pequeno, que talvez fosse por isso ele nunca tivesse pensado em rezar, em se voltar para o céu de que tanto falava o padre José Pedro quando vinha vê-los [...] (Amado, 2009, p. 35).

Apesar do pouco ou nenhum distanciamento, em um dos momentos de maior tensão da narrativa, momento em que Dora é enviada ao orfanato e Pedro Bala é preso, o narrador retoma o expediente da utilização de uma notícia para narrar os fatos acontecidos. Nesse momento, há a abertura para a descrição das cenas pelo olhar das forças antagônicas da narrativa, pois a notícia é veiculada pelo jornal que pertence a um grupo detentor do poder e, portanto, contrário aos capitães. A escolha desse expediente, entretanto, gera mais aproximação entre leitor e personagens, já que a frieza e a parcialidade da notícia despertam um sentimento de adesão à causa dos capitães.

O Jornal da Tarde trouxe a notícia em grandes títulos.

Uma manchete ia de lado a lado na primeira página: PRESO O CHEFE DOS "CAPITÃES DA AREIA"

Depois vinham os títulos que estavam em cima de um clichê, onde se viam Pedro Bala, Dora, João Grande, Sem-Pernas e Gato cercados de guardas e investigadores:

UMA MENINA NO GRUPO - A SUA HISTÓRIA - RECOLHIDA A UM ORFANATO - O CHEFE DOS "CAPITÃES DA AREIA" É FILHO DE UM GREVISTA - OS OUTROS CONSEGUEM FUGIR - "O REFORMATÓRIO O ENDIREITARÁ”, NOS AFIRMA O DIRETOR.

Sob o clichê vinha esta legenda:

Após ser batida esta chapa o chefe dos peraltas armou uma discussão e um barulho que deu lugar a que os demais moleques presos pudessem fugir. $\mathrm{O}$ chefe é o que está marcado contra cruz e ao seu lado vê-se Dora, a nova gigolete dos moleques baianos [...] (Amado, 2009, p. 191).

Assim, o narrador, ao flutuar por diversos centros de consciência, colabora com a construção do ponto de vista do romance e, mesmo que não emita julgamento, suas escolhas formais e materiais dão pistas e conduzem ao olhar sobre o mundo que o romance retrata. 
Apesar de as escolhas formais e materiais traduzirem o ponto de vista, este apresenta algumas contradições. Em primeiro lugar, dá-se preferência ao coletivo em detrimento do individual. Entretanto, o herói apresentado pela narrativa é um típico herói romanesco problemático que, em razão das agruras sofridas, aprende e, por isso, consegue realizar algo positivo.

Além disso, Pedro Bala é descrito como branco e loiro em meio a uma coletividade de negros e mestiços. Tal fato mostra mais uma vez um herói branco salvador de uma massa de excluídos.

Por se tratar de um romance da década de 30 e, portanto, engajado, é necessário que sua leitura seja feita por esse viés, mostrando que o contexto histórico influenciou a focalização apresentada na obra.

\subsubsection{O olhar sobre o mundo nas telas dos Capitães}

É importante analisar algumas particularidades estruturais no que diz respeito à questão da focalização construída na obra fílmica.

O filme tem início com a apresentação dos vários capitães, começando com a figura de Pedro Bala. As cenas de abertura do filme mostram, em plano detalhado, pegadas deixadas na areia. A câmera segue essas pegadas e, antes revelar a quem elas pertencem, há um corte para apresentar, por meio de um plano geral, uma celebração à Iemanjá. A câmera volta a mostrar as pegadas e focaliza as pernas do personagem por trás e o espectador o acompanha até ele entrar no mar. Há, na sequência, um travelling de cima para baixo focalizando um barco e, em seguida, crianças a brincar no mar. 
Em outra cena, um plano médio apresenta o personagem Gato aos espectadores e volta-se para a festa do orixá. Nesta, Iemanjá é vista, em seu cotejo, de cima para baixo (plongé).

Finalmente, a câmera focaliza o rosto de Pedro Bala através do efeito de espelho que o mesmo segura para ofertar à entidade. $\mathrm{O}$ espectador o acompanha em seu mergulho e em sua emersão da água. O personagem volta a se olhar no espelho com um sorriso enigmático e coloca o objeto no barco junto com as outras oferendas.

A câmera faz diversas vezes esse mesmo movimento: mostra a celebração a Iemanjá e volta-se para a focalização dos capitães e, assim, o telespectador é colocado em contato com Pedro Bala, Gato, Sem-Pernas, Boa Vida...

Percebe-se que o narrador fílmico é uma espécie de entidade observadora que acompanha os personagens sem participar da história, não emitindo opiniões ou juízos próprios.

A ressonância histórica que a voz narrativa assume na obra literária não é transposta para a obra cinematográfica, o que manifesta, como já observado, a escolha por não fundamentar historicamente a narrativa que apresenta, mas seguir, com certa fidelidade, o fio da ação principal da diegese.

Em relação à focalização em obras cinematográficas, Genette (apud GAUDREAULT; JOST, 2009) propõe a tripartição a seguir. A narrativa não focalizada ocorre quando o narrador é onisciente e diz mais do que sabe quaisquer personagens. A narrativa com focalização interna ocorre quando se mostra o que se passa pela mente dos personagens. Ela pode ser fixa, quando a narrativa mostra acontecimentos filtrado pela consciência de um único personagem, ou variável, quando o personagem focalizado varia. E, por fim, a focalização interna pode ser múltipla, que ocorre quando um mesmo acontecimento 
é narrado diversas vezes segundo o ponto de vista de diferentes personagens. A narrativa com focalização externa ocorre quando não se tem acesso ao fluxo de consciência dos personagens.

Na obra cinematográfica Capitães da Areia, a focalização se apresenta de forma híbrida, alternando-se de externa para interna com a predominância da primeira. Segundo Gaudreault e Jost (2009, p. 178),

[...] Às vezes, definimos a focalização externa pelo fato de os acontecimentos serem descritos do exterior, sem que tenhamos acesso ao pensamento dos personagens. Se esse critério fosse suficiente, isso significaria que todo e qualquer, desde que não em ocularização interna primária, seria construído unicamente de focalização externa.

Ora, é importante observar que, mesmo sem ajuda da voz off, o espectador pode muito bem compartilhar os sentimentos de um personagem ou pode saber o que ele sente unicamente pela codificação do trabalho do ator, de seus gestos, suas mímicas etc. [...] A exterioridade da câmera não pode ser assimilada a uma pura negação da interioridade do personagem.

Assim, pode-se afirmar que a cineasta utiliza-se da perspectiva interna, em que o espectador é colocado em contato com pensamentos e sentimentos dos personagens em diversas cenas significativas, as quais assumem esse tipo de perspectiva interna para dar materialidade ao fluxo de consciência dos capitães e conferir dramaticidade à narrativa. Para tanto, a realizadora optou pelo emprego de alguns recursos como o uso da voz off, o flashback, o close-up nas expressões dos atores e a exploração visual do gestual dos personagens.

Uma das cenas em que há a focalização interna com o emprego da voz off é a que mostra Sem-Pernas encostado numa pedra à beira do mar, batendo agressivamente com um galho no chão. A intenção dessa cena é noticiar a morte de Almiro, um dos capitães que havia sido contaminado com varíola. Sem-Pernas havia sido contra a permanência de Almiro no grupo e, então, após muito refletir, Pedro decide levar o doente à casa da família dele. Mas a doença persistiu e Almiro acabou morrendo. Sem-Pernas se sente triste e com peso na 
consciência, mas transforma esses sentimentos em revolta. Enquanto se debate na praia com expressão de fúria, há uma voz off que coloca o espectador em contato com seu pensamento: “Todo mundo sabia que Almiro ia morrer e a culpa é minha? Pra 'arranjá' lugar pro povo 'robá' eu presto. Pra 'enganá' meio mundo, eu presto, né? Depois o Almiro pega bexiga e a culpa é minha".

No clímax de sua revolta, o fluxo de consciência em voz off é quebrado pela utilização da voz in, o que confere mais dramaticidade à cena. Sem-Pernas grita "uma merda que a culpa é minha. Não fui eu que 'poes' a doença no mundo, foi? Foi, não. Mas querem dizer assim "Foi o Sem Pernas". Pois digam, eu não ligo". Sem-Pernas se revolta assim como o mar que é focalizado a sua volta.

Essa cena, aliada àquela em que o mesmo personagem chora enquanto Dona Esther conta uma história para ele dormir, bem como a cena em que ele está deitado no colo de Dora e afirma, enquanto a menina faz cafuné em seus cabelos, que já não tem mais nome, constrói, assim como o romance, o personagem mais terno e sensível dos capitães que, entretanto, no mundo da exclusão, esconde essa ternura e se traveste de revolta e de agressividade.

Há outras cenas em que a cineasta utiliza-se da voz off, mas não com a intenção de dar materialidade ao pensamentos das personagens e, sim, com o objetivo de conferir mais dramaticidade ou criar uma relação de continuidade entre cenas. Como exemplo, pode-se citar a sequência em que Padre José Pedro consegue um carrossel para ser instalado na cidade. É uma das sequências mais significativa tanto do romance quanto do livro, pois, segundo Cunha e Baseio (2012, p. 6),

[...] Conflitua-se a trágica experiência da vida cotidiana, em que os meninos, adultos precocemente, lutam pela sobrevivência - metaforizando o reino da necessidade - com a magnífica presença do Carrossel, que ressignifica e ilumina a vida dos jovens, devolvendo-lhes a possibilidade do resgate da infância e do sonho - simbolizando o reino da Liberdade [...] Essa atmosfera antitética revela-se de maneira a retratar a dramática realidade e a acenar 
para algo que ilumine uma saída, uma espécie de esperança crítica, no dizer de Bloch $^{14}$, uma utopia.

No filme, os recursos de iluminação, trilha sonora, movimento e ritmo de câmera utilizados na sequência do carrossel - conseguem transpor para o filme esse resgate momentâneo da infância vivido pelos capitães e que incute neles a esperança de "dias melhores". Essa atmosfera onírica ultrapassa a sequência do carrossel para envolver SemPernas que, na obra cinematográfica, não acompanha os outros capitães nessa experiência porque está infiltrado na casa de Dona Esther arquitetando o roubo à residência. Para incluí-lo nesse clima de sonho, ouve-se a voz off de Dona Esther, ainda no final da sequência do carrossel. A nova "mãezinha" de Sem-Pernas lê docemente uma história infantil ${ }^{15}$ para que o capitão durma e o trecho da narrativa lida, ao qual o espectador tem acesso, também metaforiza o mundo de sonho da infância, além de ser uma espécie acolhimento e chave de acesso à esperança de superação da condição de exclusão vivida pelos meninos.

No mais, para transpor para o filme o expediente inovador das notícias de jornal empregado no romance, Cecília Amado também utilizou a voz off. Antes da primeira cena em que aparecem todos os capitães reunidos no trapiche, ouve-se a voz do Professor destacada de sua imagem, lendo a notícia de jornal que fala que um grupo de meninos denominado “Capitães da Areia” havia roubado uma residência. Em seguida, a câmera ajusta a voz à imagem do Professor e depois, em um travelling, há a focalização dos meninos e de suas expressões. Alguns parecem felizes e outros, compenetrados.

Após a fuga de Pedro Bala do reformatório, um dos momentos de mais tensão da narrativa, há a recorrência do uso desse recurso. Primeiro, o telespectador tem contato apenas com a voz off de Professor que lê novamente um texto jornalístico que noticia a fuga do líder

14 BLOCH, Ernst. Filosofia da práxis e utopia concreta. São Paulo: Editora da Universidade Estadual Paulista,1993.

15 Transcrição nossa da fala de Dona Esther na cena em que lê para Sem Pernas: "Os meninos, todos eles, deram as mãos e começaram a voar em um balão todo colorido que os levou até o fim do mundo". 
dos capitães para, na sequência, se ajustar a voz à imagem e a câmera focalizar em plano em conjunto os capitães reunidos em torno dele.

O recurso da voz off será utilizado mais uma vez na sequência final do filme também pelo Professor. Nessa sequência, o personagem, em uma conversa com Zé Fuinha, releva, em uma espécie de ato visionário e tomado de imaginação, o futuro de cada capitão. É importante ressaltar que Professor é o personagem dos capitães responsável por colocar os meninos em contato com o mundo ficcional, com o imaginário, graças a sua habilidade de leitura. Assim, a escolha deste personagem para narrar, no final da história, o destino dos demais capitães é significativa. Em primeiro lugar, ele é o contador de história e, em segundo lugar, seu receptor é Zé Fuinha, uma criança de aproximadamente cinco anos.

Diferentemente da obra literária, a obra fílmica apresenta um desfecho tomado por uma atmosfera onírica e digna da literatura infantil, conferindo a cada herói-capitão um final feliz de conto de fadas, mas que foge do critério da verossimilhança. Volta Seca voltará para o sertão para virar cangaceiro valente e fará parte de histórias que as pessoas vão ler toda noite. Pirulito será o primeiro papa pobre. Boa Vida se transformará em um artista, fará música e tocará em bares (não há qualquer menção a esse lado artístico do personagem durante o filme). João Grande será proprietário de um bar, mas não há qualquer explicação de como esse personagem conseguirá recursos financeiros para tanto. Gato irá para Ilhéus abrir um cabaré e explorar os ricos fazendeiros do cacau. Sem-Pernas, mesmo com sua deficiência física, será equilibrista. Professor será um artista engajado que, em suas produções, denunciará a condições dos meninos marginalizados da Bahia. E, por fim, Pedro Bala será o herói que lutará pela liberdade.

Percebe-se pelo discurso de Professor, que ele quer amenizar a situação de exclusão vivida por aqueles meninos, bem como abrandar a ação de um determinismo social que ainda impera na sociedade porque seu interlocutor é Zé Fuinha, uma criança. Então, o intelectual do 
grupo transforma o que os capitães vivem em uma história repleta de imaginação e com final feliz. E a voz off é o recurso que, além de fazer um elo entre a sequência anterior, permite que tanto Zé Fuinha quanto o espectador entrem nessa atmosfera de fábula.

A voz off é utilizada comedidamente e, pelo que se viu, serve a diferentes propósitos: transmitir um pensamento, intensificar a dramaticidade da narrativa, atenuar um momento de tensão, criar um elo entre sequências fílmicas, corroborar com a atmosfera de fábula.

A opção por esses recursos corrobora para construir, no filme, uma focalização que naturaliza a questão da exclusão social vivida por esses meninos. Crianças de rua roubam, brigam, bebem, fumam, vivem em uma situação precária sorrindo e brincando, como se estivessem apenas participando de uma brincadeira imaginária de "mocinho e bandido".

Além dos recursos mencionados acima, a obra cinematográfico também se utiliza da técnica do flashback para colocar o espectador em contato com o fluxo de consciência do protagonista Pedro Bala.

O emprego do flashback acontece em três sequências. A primeira delas retrata a prisão de Pedro Bala no reformatório, que é subsequente a sequência da briga dos "Capitães da Areia" com o grupo do Ezequiel. No clímax da confusão, a câmera focaliza um carro de polícia e ouvem-se sirenes. Alguns capitães gritam para Pedro tomar cuidado e a ação é cortada pela utilização de uma elipse. A tela fica preta por vários segundos, o que causa estranhamento no espectador. Em seguida, inicia-se nova sequência, mas já com Pedro Bala em confinamento no reformatório. A câmera focaliza o líder dos capitães e inicia-se o flashback em que o espectador toma conhecimento do que aconteceu com Pedro Bala antes de ele chegar à chamada "cafua".

A cena que inicia a rememoração do personagem mostra um corredor extenso e fora de foco. Pedro Bala caminha por essa via até chegar a uma espécie de portão de cadeia, que é 
aberto. O som da abertura do portão é hiperbólico e agudo, o que causa incômodo no espectador. Pelos seus machucados, percebe-se que foi torturado. Ele é levado à sala do diretor do reformatório, que, enquanto discursa de forma conservadora, autoritária e determinista, tem sua imagem ampliada pela câmera. Tal técnica o descreve como o opressor que subjuga o protagonista da narrativa e determina que ele volte para o confinamento. $\mathrm{Na}$ volta à cafua, testemunha-se o fluxo de consciência desordenado e convulsionário de Pedro. Lembranças e alucinações povoam os pensamentos do menino.

A segunda utilização do recurso do flashback se dá na sequência que mostra o ritual de candomblé para a cura de Dora. Após a libertação de uma pomba branca, a câmera centrase em Pedro, que fecha os olhos e chora enquanto segura a mão da amada. Nesse momento, há a focalização interna do personagem, que relembra os momentos em que os dois brincavam na praia em um dia ensolarado. A iluminação e o cenário criam uma sensação de conforto e acolhimento que abrandam a realidade de angústia do líder dos Capitães.

A terceira e última utilização do flashback ocorre na cena em que Pedro acorda e percebe que Dora está morta. O desespero e a tristeza de Pedro são suspensos pelas lembranças que voltam a povoar sua mente. Pedro e Dora navegam em um saveiro em águas calmas. Nessas cenas, a iluminação, as cores e a fotografia também agem como uma espécie de eufemismo para o momento de tensão vivenciado pelos personagens. Há um tom solar, imitando a iluminação natural, que confere uma sensação de ambiente agradável e de aconchego. As cores são leves: optou-se pelo uso do branco, azul e da cor de areia para criar a sensação de que as crianças viviam em uma situação de liberdade aprazível.

Analisando os momentos de utilização da técnica do flashback, verifica-se que em todos eles há a fuga do personagem para um cenário idílico em companhia de Dora. Essa fuga da realidade cria, na obra cinematográfica, uma quebra do desconforto gerado pelos conflitos enfrentados pelo protagonista e o abrandamento da precariedade em que vivem os meninos. 
Além dessas técnicas, que permitem acessar o fluxo de consciência das personagens, ao espectador são dadas dicas acerca dos sentimentos e reações destas pelas expressões faciais e gestuais dos atores.

É importante frisar que, apesar de haver a utilização de técnicas que possibilitam a utilização da focalização denominada filter, ou seja, aquela que dá acesso ao mundo interior da personagem, a cineasta preferiu a utilização de planos em que o espectador permanece a uma distância convencional, não sendo chamado a participar diretamente nas cenas que acompanha.

Quanto ao ponto de vista, nota-se que não coincide com o de nenhuma instância intradiegética, já que se optou pela predominância de planos conjuntos e gerais, que são clássicos, muito comuns ao chamado cinema narrativo. São planos em que se utiliza uma perspectiva que se identifica facilmente com o olhar habitual e, desta forma, o espectador é levado a esquecer-se de que entre ele e a cena existe um aparato tecnológico que regista essa imagem. O uso desse aparato também auxilia na construção da focalização.

Segundo Ismail Xavier (2003, p. 74), a câmera não apenas mostra como também narra, pois, faz escolhas ao contar, eleger um ângulo, a distância e o modo de olhar. Desse modo, ela que vai mostrando os acontecimentos e guiando o olhar do espectador para que ele adira a um determinado ponto de vista.

Outro recurso que também contribui para a construção da focalização é a trilha sonora.

De acordo com Martin (2007, p. 114),

[...] enquanto a imagem de um filme é uma sequência de fragmentos, a trilha sonora restabelece de certo modo a continuidade, tanto ao nível da simples percepção quanto ao da sensação estética; a trilha sonora é efetivamente, por natureza e necessidade, bem menos fragmentada que a imagem: em geral é relativamente independente da montagem visual e muito mais de acordo com o "realismo" no que concerne ao ambiente sonoro; de resto, o papel da 
música é primordial como fator de continuidade sonora ao mesmo tempo material e dramática.

Sob essa perspectiva, nota-se que a trilha sonora contribui para dar impressão de realidade à imagem e, ao mesmo tempo, confere carga dramática à ação que está sendo mostrada. Desta forma, atua na construção da focalização e, também, auxilia para que o espectador adira ao ponto de vista que a narrativa adota.

A produção da trilha sonora do filme Capitães da Areia foi realizada pelo músico brasileiro Carlinhos Brown que, além de estabelecer parceria com Arnaldo Antunes, Marisa Monte e o músico angolano Dog Murras, compôs algumas das letras das canções que fazem parte da obra cinematográfica.

Ao se analisar a trilha sonora da obra, percebe-se sua perfeita associação com a imagem, ajudando na continuidade das sequências, na potencialização da dramaticidade, na construção dos personagens e, também, na construção do retrato da cultura baiana.

Na letra da música de abertura e de fechamento do filme, denominada Talavera, são utilizados diversos termos do Candomblé oriundos de línguas e dialetos africanos. Essa canção, por ser uma espécie de culto a Iemanjá, associa-se às sequências inicial e final do filme nas quais se mostra um cortejo à rainha do mar. Usa-se como base instrumentos de percussão, como atabaques, que também são utilizados em rituais dessa religião, o que torna imagem e som indissociáveis.

A melodia da música Tema de Dora, de autoria de Carlinhos Brown, remete à ideia de aconchego e acolhimentos que fazem parte das características psicológicas da personagem Dora. A única capitã do grupo é a menina-moça que faz papel de mãe, irmã, namorada e, também, capoeirista. Assim como no romance, Dora é uma personagem feminina forte, mas que não perde sua ternura. A narrativa cinematográfica transpôs para a tela a mesma Dora 
doce da narrativa literária. Além de ter tido sucesso na escolha da atriz que interpreta a personagem, Cecília Amado utilizou-se de recursos como a iluminação que passa a ter um tom de areia, um tom dourado após a chegada da menina no grupo, o que cria um ambiente aprazível e de bem-estar. Além disso, a letra de Tema De Dora contribui para essa construção tanto pela melodia harmoniosa e calma quanto pela letra. Novamente, a trilha sonora casa-se perfeitamente com a diegese do filme.

Já nas cenas de ação do filme, a música de fundo é Capoeira Futuro. também de autoria de Carlinhos Brown. Por meio de um ritmo de embolada acelerado e de uma base de capoeira de cavalaria, ela potencializa o efeito de ação que se objetiva transmitir.

Na sequência do carrossel percebe-se junção indissociável entre imagem e som. A música Contato Imediato, de Arnaldo Antunes alia-se à iluminação para, dessa forma, produzir um efeito de sonho e de escapismo para a infância e seu universo de magia e de imaginação.

Por fim, a música Doce do Mar, de Arnaldo Antunes em parceria com Carlinhos Brown, é o tema do romance de Pedro Bala e Dora. Com sua riqueza melódica inspirada em Dorival Caymmi, a canção corrobora para a criação da atmosfera de amor do casal protagonista da história, bem como para a atenuação da situação de tensão gerada pela doença de Dora, sem contar a carga dramática que confere à sequência em que é empregada.

Portanto, na obra cinematográfica Capitães da Areia, a trilha sonora se associa de forma sincrônica às imagens de forma harmoniosa e não cria qualquer estranhamento por parte do espectador. Pelo contrário, potencializa a carga dramática contribuindo para que o público siga e adira ao ponto de vista que a obra apresenta, colaborando na constituição da unidade da obra. Além disso, muitas vezes auxilia na construção de uma atmosfera de fábula, atenuando a situação de exclusão em que vivem os personagens. 
Nota-se, portanto, que tanto no que diz respeito à focalização, como ao papel do narrador e à construção das personagens, a obra cinematográfica se ateve ao nível superficial do romance, eliminando o que há de teor ideológico da obra literária ao amenizar, por meio de escolhas e empregos de técnicas audiovisuais, passagens mais ambíguas ou complexas. Os princípios adotados são os da atenuação e condensação que, por consequência, geram simplificação do conteúdo. Criou-se um conteúdo fílmico baseado em uma visão muito romantizada quanto à questão da criança excluída, deu-se ênfase às traquinagens dos capitães e, também, ao romance de Pedro e Dora. Assim, a construção da crítica social não progrediu e a questão dos menores abandonados e colocada para segundo plano. 


\section{Considerações Finais}

Livro e filme estão distanciados no tempo: escritor e cineasta não têm exatamente a mesma sensibilidade e perspectiva, sendo, portanto, de esperar que a adaptação dialogue não só com o tempo de origem, mas com seu próprio contexto, inclusive atualizando a pauta do livro. (XAVIER, 2003, p.62)

Sob a ótica dos Estudos Comparados de Literaturas de Língua Portuguesa, é importante que, em meio a um contexto de globalização econômica e de estandardização cultural, se analise os diálogos que a literatura estabelece com outras artes, procurando não mais se instituir uma hierarquia entre as produções artísticas, baseada no critério de fonte e influência mas sim, adotando-se uma perspectiva de ordem interdisciplinar e solidária para se aprofundar nas imbricações estéticas e ideológicas que podem revelar as marcas da identidade de uma nação.

Assim, a investigação das relações entre a literatura e outras manifestações artísticas requer olhar para essa confluência como um fenômeno complexo e, principalmente, como algo inseparável da cultura, história e sociedade.

Ao se estudar a interação entre o romance amadiano Capitães da Areia e o filme homônimo de Cecília Amado, adotou-se esse olhar para se discutir como tais obras, por meio de alguns de seus elementos narrativos, podem refletir o contexto histórico no qual foram produzidas bem como os posicionamentos político e estético de seus autores.

Em relação a Jorge Amado, é indiscutível sua contribuição para a formação de marcas identitárias do Brasil e a expressão internacional delas já que se trata de um dos autores brasileiros mais lidos no mundo. E não se pode deixar de lado seu legado para todos os países de Língua Portuguesa, bem como para os países da extinta União Soviética, que enxergaram na literatura amadiana uma fonte de inspiração e resistência. Além disso, Amado 
é o autor brasileiro que mais teve suas obras adaptadas para outros suportes, tais como cinema, teatro, dança, quadrinhos, entre outros.

Dessa forma, Amado contribuiu para a formação de nossa identidade cultural e nacional, bem como para a projeção de nossa gente e nossos costumes além de nossas fronteiras, sem deixar de lado as causas sociais e políticas.

Apesar de sua relevância, a academia debruça-se pouco sobre sua produção literária. Capitães da Areia, por exemplo, é um dos romances mais publicados, traduzidos e adaptados do autor, no entanto há poucos estudos a seu respeito e a explicação para isso, talvez, seja o fato de grande parte da crítica e da cultura letrada brasileira o considerar um autor de livros vendáveis. Por essa razão, torna-se imprescindível um olhar mais atento sobre ele e suas adaptações, sem o estigma de autor de best sellers e sem considerar as adaptações obras menores.

Assim, em meio a diversas transposições da obra literária Capitães da Areia, elegeuse a adaptação fílmica mais recente da obra por sua atualidade e, também, por ter sido realizada pela neta do autor. Cecília Amado, em 2011, lançou o filme Capitães da Areia, que se configura como uma releitura do romance escrito por seu avô.

Ressalta-se que, ao se analisar como decorre o diálogo entre a narrativa literária e a narrativa fílmica dos Amados, buscou-se discutir como se deu as relações entre seus diferentes códigos e linguagens, verificando suas aproximações e distanciamentos a partir das especificidades apresentadas de cada manifestação artística.

Durante o percurso desta pesquisa, a ótica comparativa tradicional que elege parâmetros de fonte e influência foi deixada de lado. Também não se questiona qualquer critério de fidelidade com relação à obra de partida, como já fora dito acima. A adaptação, 
portanto, é vista como outro texto em diálogo com um extensivo conjunto de outros textos e com os quais forma uma pluralidade de significados.

Dentro dessa perspectiva, vimos que a narrativa literária Capitães da Areia foi escrita em um contexto histórico marcado pela bipolarização do mundo em dois blocos: capitalista e socialista. Além disso, era início do Estado Novo de Getúlio Vargas, governo totalitário e antissocialista. Tal momento histórico clamava por um posicionamento político das vozes críticas e, portanto, a arte começa a se configurar como manifestação engajada e voltada para a denúncia das questões sociais. Através dos movimentos artísticos, os marginalizados ganham voz e vez.

Em Capitães da Areia, meninos de rua viram protagonistas e heróis. Em cena, eles se impõem e desvelam a desigualdade social brasileira, mas deixam uma esperança de superação, pois, são tempos de utopia.

Pela primeira vez, escreve-se sobre menores carentes e, nesse aspecto, o livro é inovador. Ele também o é quando adota outros expedientes, tais como: o conjunto de cartas que inicia o romance - o que confere verossimilhança à narrativa e ao mesmo tempo insere índices de contradições sociais que suscitam reflexão crítica; - a forma que constrói Dora como uma personagem feminina forte, - as questões religiosas e culturais que retrata entre outros.

Como escritor de partido, Jorge Amado estava comprometido em "escrever para a massa e sobre a massa" e tal engajamento refletiu em suas primeiras obras. Assim, a escolha do autor por uma linguagem próxima do oral a opção por retratar personagens excluídos, por criar uma história entremeada por uma ideologia socialista, por eleger um narrador que adere à causa dos meninos, por adotar uma estrutura romanesca e próxima ao folhetim decorrem do 
amálgama de um projeto político e estético que se configura no bojo de um determinado panorama histórico.

Essas escolhas são índices do olhar de mundo adotado pela obra, ou seja, aquele que vê o mundo polarizado em duas classes - dos abastados e a dos excluídos- as quais se opõem constantemente. Lugar em que a desigualdade social é consequência de um sistema que oprime, gerando violência e exclusão. Como solução, o romance indica a coletivização, a união dos excluídos e sua organização a fim de promover uma revolução socialista e, de forma utópica, colocar o mundo nos eixos.

Em relação à adaptação fílmica, ela foi realizada em outro contexto histórico em que houve, após a queda do murro de Berlim, um declínio da ideologia socialista e, com ela, um apagamento das esperanças revolucionárias utópicas. Vivemos um momento de diluição de fronteiras, de confluência de pensamentos e de posicionamentos em razão da globalização e da potencialização do consumo.

Segundo Cunha e Baseio (2011, p. 11),

[...] o contexto atual vivencia o declínio das esperanças revolucionárias utópicas, o que vem mobilizando um novo mapeamento das possibilidades políticas e culturais. A linguagem da revolução cede lugar aos idiomas da resistência, indicando uma mudança dos projetos emancipatórios ${ }^{16}$. Em face do fenômeno da globalização que negocia comunidades envolvidas em um processo complexo de produção e consumo, qualquer orientação política passa pela questão de identidade, orientando lutas pela autorrepresentação de comunidades marginalizadas pelo direito de falar por si mesmo ${ }^{17}$, no entanto, essas comunidades, não raro, apoiam-se em categorias análogas às que rejeitam, esvaziando o sentido de sua resistência.

É nesse contexto que Cecília Amado produz sua obra cinematográfica partindo do romance de seu avô. O olhar sobre o mundo de que está imbuído o filme também reflete esse contexto, bem como o posicionamento estético e político da cineasta. Ao dar diferente

\footnotetext{
${ }^{16}$ STAM, Robert. A literatura através do cinema: realismo, magia e a arte da adaptação. Belo Horizonte: Editora UFMG, 2008, p.441.

${ }^{17}$ Ibid., p.445.
} 
enfoque à questão ideológica presente no romance, a realizadora já mostra sua posição em consonância com o panorama atual. Além disso, não se pode esquecer que questões externas referentes às de patrocínio, exibição e distribuição da obra cinematográfica têm um peso considerável hoje em dia.

Nesse sentido, Cecília Amado priorizou, como se verificou pelas análises, a questão mais humana, dando enfoque à história de amor de Bala e Dora e apenas tocando em aspectos críticos da sociedade brasileira, sem aprofundá-los. É possível ver a tentativa de crítica de nossa realidade, mas é uma tentativa muito tímida e que não decola. Além disso, há uma romantização da questão do menor abandonado e do ambiente degradado em que eles vivem.

Em relação aos recursos técnicos, eles corroboram a construção desse olhar e o resultado são fotografias belíssimas, mas que retratam de forma eufemizada a realidade social brasileira.

Por fim, nota-se que a relevância deste estudo reside no fato de ele, além de contribuir para as pesquisas acadêmicas da área de Estudos Comparados de Literaturas de Língua Portuguesa uma vez que apresenta indagações que abordam, em diferentes aspectos, o diálogo entre literatura e cinema, também levanta questões importantes que permitem uma reflexão sobre o alinhamento do contexto de produção e os respectivos projetos políticos e estéticos de seus autores. 


\section{Referências Bibliográficas}

ABDALA JR., Benjamin. A escrita neo-realista. São Paulo: Ática, 1981.

A literatura, o comunitarismo e a condição intelectual. Muitas Vozes, Ponta Grossa, v.1, n.1, p. 11-28, 2012 b.

De voos e Ilhas: Literatura e Comunitarismos. São Paulo: Ateliê Editorial, 2007.

Editorial, 2012.

Literatura Comparada \& Relações Comunitárias, Hoje. São Paulo: Ateliê

Literatura, História e Política: literaturas de língua portuguesa no século XX. São Paulo: Ateliê Editorial, 2007.

AMADO, Jorge. Capitães da Areia. São Paulo: Companhia das Letras, 2009.

Navegação de Cabotagem- apontamentos para um livro de memória que jamais escreverei. Rio de Janeiro: Record, 2006.

O Mundo da Paz. Rio de Janeiro: Editorial Vitoria, 1952.

AMBIRES, Juarez Donizete. O Neorrealismo em Portugal: escritores, história e estética. Revista Trama, Marechal Cândido Rondon, v. 9, n. 17, p. 98, 1. sem. 2013.

ANDREW, Dudley. Adaptation. In: NAREMORE, James. Film Adaptation. New Jersey: Rutgers, 2000, p. 29-37.

BAPTISTA, Mauro; MASCARELlO, Fernando (Orgs.). Cinema Mundial Contemporâneo. Campinas, SP: Papirus, 2008.

BARTHES, Roland. Análise estrutural da narrativa. 2. ed. Petrópolis: Vozes, 1972.

BASTIDE, Roger. Sobre o romancista Jorge Amado. In: Vários Autores - Jorge Amado: povo e terra: 40 anos de literatura. São Paulo, Martins Fontes, 1972, p. 23-48.

BAZIN, André. O que é cinema? Tradução de Ana Moura. Lisboa: Horizonte, 1992. (Coleção Horizonte de Cinema).

BELLO, Maria do Rosário Leitão Lupi. Narrativa Literária e Narrativa Fílmica: o caso de Amor de Perdição. Coimbra: Fundação Calouste Gulbenkian, 2008.

BENJAMIN, Walter. Charles Baudelaire, um lírico no auge do capitalismo. Obras Escolhidas III. Tradução de José Martins Barbosa e Hermerson Alves Batista. São Paulo: Brasiliense, 1989.

Magia, técnica, arte e política. São Paulo: Brasiliense, 1987.

BERNADET, Jean-Claude. O que é o cinema. São Paulo: Brasiliense, 2006. 
BLOCH, Ernst. Filosofia da práxis e utopia concreta. São Paulo: Editora da Universidade Estadual Paulista,1993.

BLUESTONE, George. Novel into film- the metamorphosis of fiction into cinema. Berkeley: University of California Press, 1973.

BOOTH, Wayne. Distance and point of view - a essay in classification. In STEVICK, Philip. The theory of novel. New York: The Free Press, 1967, p. 87-107.

BOSI, Alfredo. Fenomenologia do olhar. In: NOVAES, Adauto (Org.). O Olhar. São Paulo: Companhia das Letras, 1988, p. 65-87.

Entre a Literatura e a História. São Paulo: Editora 34, 2013.

n.10, p. $11-28$.

Narrativa e resistência. Itinerários - Revista de Literatura Araraquara, SP, 1996,

BORDWELL, David. O cinema clássico hollywoodiano: normas e princípios narrativos. In: RAMOS, Fernão Pessoa. (Org.). Teoria Contemporânea do Cinema: documentário e narratividade ficcional. São Paulo: Senac-SP, 2005, p. 278-279. v. 2.

Narration in the fiction film. London: Methuen, 1985.

CANDIDO, Antonio. A educação pela noite \& outros ensaios. São Paulo: Ática, 1989.

1976.

Literatura e Sociedade: estudo de teoria e história literária. São Paulo: Nacional,

Poesia, documento e história. In:

Brigada Ligeira. São Paulo: Unesp, 1992.

CANDIDO, Antonio et al. A Personagem de Ficção. São Paulo: Perspectiva, 1976.

CAPITÃES da Areia. Direção de Cecília Amado. Rio de Janeiro: Globo Filmes, 2011. 1 bobina cinematográfica, 96 minutos, cor.

CARELLI, Fabiana. Jorge dos Subterrâneos - Literatura, História e Política no Estado Novo. São Paulo, 2012. No prelo.

CARELLI, Fabiana Buitor. Porões da memória - ficção e história em Jorge Amado e Graciliano Ramos. Dissertação (Mestrado em Literatura Comparada), Faculdade de Filosofia, Letras e Ciências Humanas da Universidade de São Paulo, São Paulo, 1997.

CARVALHAL, Tania Franco. Literatura comparada. São Paulo: Ática, 1999.

Intertextualidade: a migração de um conceito. In: Via Atlântida, São Paulo, n. 9, jun. 2006, p. 125-136.

Literatura Comparada: a estratégia interdisciplinar. In Revista Brasileira de Literatura Comparada, Rio de Janeiro, n.1, 1991, p. 9-16.

CARVALHAL, Tania Franco; COUTINHO, Eduardo de Faria. Literatura comparada: textos fundadores. Rio de Janeiro: Rocco, 1994. 
CASTRO, Andrea Trench. O romance-folhetim de Camilo Castelo Branco e Eça de Queiroz. Dissertação (Mestrado em Estudos Comparados de Literaturas de Língua Portuguesa), Faculdade de Filosofia, Letras e Ciências Sociais da Universidade de São Paulo, São Paulo, 2012.

CHAVES, Rita. Angola e Moçambique: experiência colonial e territórios literários. São Paulo: Ateliê Editorial, 2005.

COUTO, Mia. E se Obama fosse africano? São Paulo: Companhia das Letras, 2011.

CUNHA, Maria Zilda. Nas sendas de encanto e sonhos, uma língua de brincar: contatos e ressonâncias na literatura infantil e juvenil de língua portuguesa. In: II Simpósio Mundial de Estudos de Língua Portuguesa, 2, 2009, Évora. Disponível em: <http://www. simelp2009.uevora.pt/pdf/slt58/05.pdf>. Acesso em: 12 jan 2014.

CUNHA, Maria Zilda; BASEIO, Maria Auxiliadora Fontana. Diálogos entre Literatura e cinema: o neorrealismo em Capitães da Areia, de Jorge Amado. São Paulo: 2012. No prelo.

CUSTÓDIO, Paula Leocádia Pinheiro. O olhar cinematográfico no filme Rio de Carlos Saldanha. São Paulo, 2011. No prelo.

DEBORD, Guy. A Sociedade do Espetáculo: comentários sobre a sociedade do Espetáculo. Rio de Janeiro: Contraponto, 2009.

DUARTE. Eduardo de Assis. Jorge Amado: Romance em tempo de Utopia. Rio de Janeiro: Record, 1996.

Jorge Amado, exílio e literatura. In: Revista digital Aletria, 2002, p.226-236. Disponível em: www.periodicos.letras.ufmg.br/index.php/aletria>. Acesso em: 15 jan. 2015.

Leitura e Cidadania. Disponível em: <http://www.unicamp.br/iel/memoria/ projetos/ensaios/ensaio19.html >. Acesso em: 10 ago. 2012.

Literatura, Revolução, Utopia. In: Limites, $3^{\circ}$ Congresso Abralic. São Paulo: Edusp, 1995, p. 122-417.

EPSTEIN, Jean. O cinema e as letras modernas. In: XAVIER, Ismail (Org.). A experiência do cinema. Rio de Janeiro: Graal, 1991.

EVERDOSA, Carlos. Roteiro da literatura angolana. Luanda: União dos Escritores Angolanos, 1979.

FABRIS, Mariarosaria. Neo-realismo Italiano. In: MASCARELO, Fernando (Org.). História do Cinema Mundial. Campinas: Papirus, 2006, p. 191-219.

FREITAS, Ricardo de Oliveira. Jorge Amado e o livro na tela: adaptações da literatura para o audiovisual. In: SANTOS, Flávio Gonçalves (Org.). Colóquio Internacional 100 Anos de Jorge Amado: História, Literatura e Cultura. Ilhéus: Editus, 2013. 
GAUDREAULT, André: JOST, François. A narrativa cinematográfica. Tradução de Adalberto Müller, Ciro Inácio Marcondes e Rita Jover Faleiros. Brasília: Editora Universidade de Brasília, 2009.

GUIMARÃES, Hélio. O romance do século XIX na televisão: observações sobre a adaptação de Os Maias. In: PELLEGRINI, Tânia et al. Literatura, cinema e televisão. São Paulo: Senac-SP; São Paulo: Instituto Itaú Cultural, 2003, p. 91-114.

HÚNGARO, Susana Regina Vaz. Romance, revolução e utopia: um estudo comparado entre Capitães da Areia, Levantando do Chão e A Geração Utopia. Dissertação (Doutorado em Literatura Comparada) Faculdade de Filosofia, Letras e Ciências Humanas da Universidade de São Paulo, São Paulo, 2004.

HUTCHEON, Linda. A theory of adaptation. New York: Routledge, 2006.

JAMES, Henry. The art of the novel: critical preface. New York: Scribers, 1937.

JEZDZIKOWSKI, Jaroslaw. Pilar do Comunismo ou escritor exótico? A recepção dos romances de Jorge Amado na Polônia. In: TradTerm, São Paulo, n. 17, 2010, p. 127-156.

KRISTEVA, Julia. Introdução à semanálise. São Paulo: Perspectiva, 1974.

MARQUEZINI, Fabiana Carelli. Aos cacos: imagens da nação angolana em As aventuras de Ngunga e Na cidade vazia, livro e filme. In: Via Atlântica, São Paulo, n. 13, 2008, p. 181193.

MARTIN, Marcel. A Linguagem Cinematográfica. Tradução de Paulo Neves. São Paulo: Brasiliense, 2007.

MARTIN, Vima Lia; MORAES, Anita M. Rodrigues. O Brasil e a poesia africana de literatura de língua portuguesa. In: Revista Scripta, Belo Horizonte, v. 15, n. 29, 2011, p. 6984.

METZ, Christian. A significação no cinema. São Paulo: Perspectiva, 1972.

MONCAU, Gabriela. Entrevista. Caros amigos. São Paulo: Caros Amigos, nov. 2011. Disponível em: <http://carosamigos.terra.com.br/index/index.php/cultura/noticias/1887entrevista-cecilia-amado-fala-sobre-a-producao-do-filme-capitaes-de-areia>. Acesso em: 10 ago. 2012.

MORAES, Dênis de. O imaginário vigiado: a imprensa comunista e o realismo socialista no Brasil. Ri de Janeiro: José Olympio, 1994.

NAMORADO, Egídio. Situação do neo-realismo em Portugal. Coimbra: Vértice, 1959.

NAREMORE, James. Film Adaptation. New Jersey: Rutgers, 2000.

NITRINI, Sandra. Literatura Comparada: História, Teoria e Crítica. São Paulo: EDUSP, 1998.

NITRINI, Sandra et al (Orgs.). Literaturas, artes, saberes. São Paulo: Aderaldo \& Rothschild; ABRALIC, 2008. 
PAES, José Paulo. Quincas Berro d'Água ou a morte carnavalizada. In: ROLEMBERG, Vera (Org.). Um grapiúna no país do carnaval. Salvador: Fundação Casa de Jorge Amado, 2000, p. 35-40.

O ESTADO DA BAHIA. Salvador: 17 dez. 1937. Disponível em: <http://www.unicamp.br /iel/memoria/projetos/ensaios/ensaio19.html>. Acesso em:

RAMOS, Graciliano. Linhas tortas. Rio de Janeiro: Record, 2005.

RANCIÈRE, Jacques. A partilha do sensível - estética e política. Tradução de Mônica Costa. São Paulo: Editora 34, 2009.

REIS, Carlos. O discurso ideológico do neo-realismo português. Coimbra: Almedina, 1983, p. 29.

ROCHA, João Cezar de Castro. Um projeto de Ficção Multimídia. O Estado de S. Paulo, São Paulo, 4 ago. 2012, Sabático, p. 5.

ROSINHA, Maria da Luz. Jorge Amado e o neorrealismo português: uma teia de laços e influências. In: SANTOS, David. Jorge Amado e o neorrealismo português. Lisboa: CLEPUL, 2012.

SALEM, Helena. Nelson Pereira dos Santos: o sonho possível do cinema. São Paulo: Record, 1996.

SANTILLI, Maria A. Identidade e justiça, categorias éticas e estéticas: o próprio e o comum nas Literaturas de Língua Portuguesa. In: Paralelas e Tangentes entre as Literaturas de Língua Portuguesa. São Paulo: Arte \& Ciência, 2003, p. 251-272. (Coleção Via Atlântica).

SERCENKO, Nicolau. A corrida para o século XXI - no loop da montanha russa, São Paulo: Companhia das Letras, 2001.

SHOHAT, Ella; STAM, Robert. Crítica da Imagem Eurocêntrica: multiculturalismo e representação. Tradução de Marcos Soares. São Paulo: Cosac Naify, 2006.

SOUSA, Sérgio. Relações intersemiótica entre o cinema e a literatura. A adaptação cinematográfica e a recepção literária no cinema. Braga: Universidade do Minho, 2001.

STAM, Robert. Teoria e Prática da adaptação: da fidelidade à intertextualidade. In: Ilha do Desterro, Florianópolis, n. 51, páginas 19-53, jul-dez 2006. Disponível em: < http://www. periodicos.ufsc.br/index.php/desterro/article/viewFile/2175-8026.2006n51p19/9004>. Acesso em: 19 jul. 2014.

TARDÁGUILA, Cristina. Entrevista. O Globo. Rio de Janeiro: Globo, 6 ago. 2011, Seção Em Família. Disponível em: <http://oglobo.globo.com/cultura/cecilia-amado-lanca-emutubro-longa-metragem-inspirado-no-best-seller-capitaes-de-areia-publicado-por-seu-avo-em1937-2705628\#ixzz3Ae4BLzXD>. Acesso em: 8 set. 2014.

TODOROV, Tzvetan. As Categorias da Narrativa Literária. In: Análise Estrutural da Narrativa. Tradução de Maria Zélia Barbosa Pinto. Petrópolis: Vozes, 1973, p. 209-254. 
VANOYE, Francis; GOLIOT-LÉTÉ, Anne. Ensaio sobre a análise fílmica. Tradução de Marina Appenzeller. Campinas: Papirus, 2005.

XAVIER, Ismail. O discurso cinematográfico: a opacidade e a transparência. São Paulo: Paz e Terra, 2005.

O olhar e a cena - melodrama, Hollywood, Cinema Novo, Nelson Rodrigues. São Paulo: Cosac \& Naify, 2003b.

Do texto ao filme: a trama, a cena e a construção do olhar no cinema. In:

PELLEGRINI, Tânia et al. Literatura, cinema e televisão. São Paulo: Senac-SP; São Paulo: Instituto Itaú Cultural, 2003, 61-89.

O olhar e a voz: a narração multifocal do cinema e a cifra da História em São Bernardo. In: Literatura e Sociedade, São Paulo, n. 2, 1997, 126-138. 